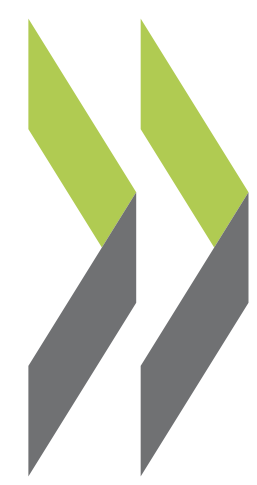

OECD Economics Department Working Papers No. 1447

The effects of the tax mix on inequality and growth

Oguzhan Akgun, Boris Cournède, Jean-Marc Fournier

https://dx.doi.org/10.1787/c57eaa14-en 
Organisation de Coopération et de Développement Économiques

Organisation for Economic Co-operation and Development

11-Dec-2017

ECONOMICS DEPARTMENT

English - Or. English

\section{THE EFFECTS OF THE TAX MIX ON INEQUALITY AND GROWTH}

ECONOMICS DEPARTMENT WORKING PAPERS No. 1447

By Oguzhan Akgun, Boris Cournède and Jean-Marc Fournier

OECD Working Papers should not be reported as representing the official views of the OECD or of its member countries. The opinions expressed and arguments employed are those of the author(s).

Authorised for publication by Christian Kastrop, Director, Policy Studies Branch, Economics Department.

All Economics Department Working Papers are available at www.oecd.org/eco/workingpapers

This document, as well as any data and map included herein, are without prejudice to the status of or sovereignty over any territory, to the delimitation of international frontiers and boundaries and to the name of any territory, city or area. 
OECD Working Papers should not be reported as representing the official views of the OECD or of its member countries. The opinions expressed and arguments employed are those of the author(s).

Working Papers describe preliminary results or research in progress by the author(s) and are published to stimulate discussion on a broad range of issues on which the OECD works.

Comments on Working Papers are welcomed, and may be sent to OECD Economics Department, 2 rue André Pascal, 75775 Paris Cedex 16, France, or by e-mail to eco.contact@oecd.org.

All Economics Department Working Papers are available at www.oecd.org/eco/workingpapers.

The statistical data for Israel are supplied by and under the responsibility of the relevant Israeli authorities. The use of such data by the OECD is without prejudice to the status of the Golan Heights, East Jerusalem and Israeli settlements in the West Bank under the terms of international law.

\section{(C) OECD (2017)}

You can copy, download or print OECD content for your own use, and you can include excerpts from OECD publications, databases and multimedia products in your own documents, presentations, blogs, websites and teaching materials, provided that suitable acknowledgment of OECD as source and copyright owner is given. All requests for commercial use and translation rights should be submitted to rights@oecd.org 
ECO/WKP(2017)79

\section{ABSTRACT/RÉSUMÉ \\ The effects of the tax mix on inequality and growth}

Can reforms that shift the balance among different taxes in the revenue mix lastingly influence the overall prosperity of an economy and the distribution of income across households? The present study takes this question to the data, using the experience of 34 OECD countries over 1980-2014 to assess the effects of changes in the tax structure on the long-term level of average output per capita and the distribution of disposable income across households. Changing the revenue mix while keeping government size constant typically lift long-term output per capita when they involve cuts in the labour tax wedge below or above average incomes, cuts in corporate income taxes or increases in property taxes. The relative-income effects of revenue-neutral reductions in labour tax wedges are broadly in line with intuition: the relative position of those benefitting from them typically improves. In absolute terms, however, nearly all the income distribution benefits from revenue-neutral reductions in labour tax wedges, be they focused on below or average income earners.

JEL codes: H2; H11; H23; H24; H25; H27

Keywords: tax, taxation, growth, inequality, household disposable income

$* * * * *$

\section{Les effets de la structure fiscale sur les inégalités et la croissance}

Les réformes qui modifient l'équilibre entre les différentes taxes peuvent-elles influencer la prospérité à long terme d'une économie et la distribution des revenus entre les ménages ? La présente étude répond à cette question au moyen d'analyses économétriques qui mobilisent l'expérience accumulée par 34 pays de l'OCDE au cours des décennies 1980-2014. Ces analyses évaluent les effets des changements de structure fiscale sur le niveau à long terme du produit intérieur brut (PIB) par habitant et la distribution du revenu entre les ménages. Les réformes de structure fiscale à taille inchangée du gouvernement en général augmentent le PIB par habitant lorsqu'elles mettent en œuvre des réductions du coin fiscal sur le travail (aussi bien sur les bas que sur les hauts revenus), des réductions de l'impôt sur les sociétés et des augmentations des impôts sur la propriété. Les effets estimés de réductions du coin fiscal à recettes globales inchangées sur la distribution des revenus sont conformes à l'intuition : ceux qui en bénéficient voient leurs revenus s'élever relativement à la moyenne. En termes absolus, cependant, l'ensemble de la distribution des revenus bénéficie quasiment tout entier d'une réduction du coin fiscal, que celle-ci porte sur les bas ou les hauts revenus.

Classification JEL : H2 ; H11 ; H23 ; H24 ; H25 ; H27

Mots-clefs : fiscalité, taxes, taxation, croissance, inégalités, revenu disponible des ménages 


\section{TABLE OF CONTENTS}

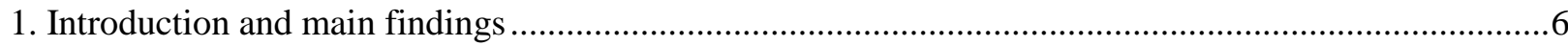

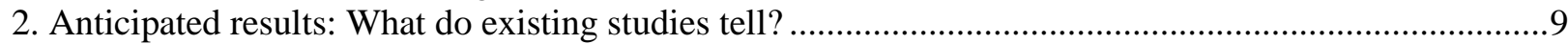

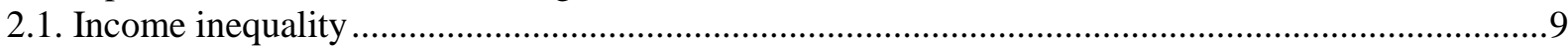

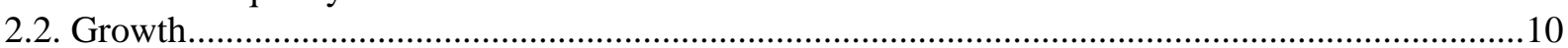

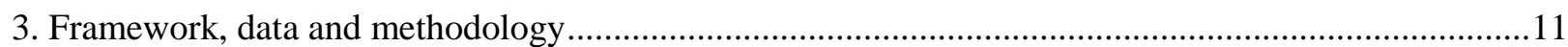

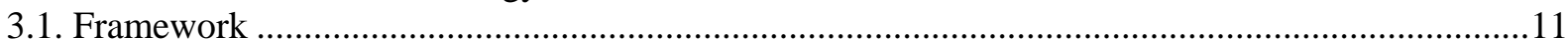

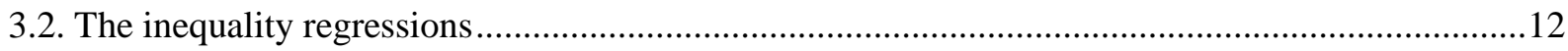

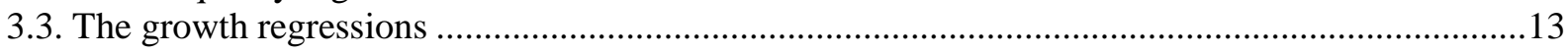

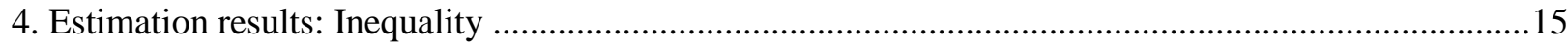

4.1. Inequality effects of tax shifts involving changes in CIT, PIT or VAT rates all considered together 15

4.2. A focus on the inequality effects of personal income tax and the labour tax wedge .....................17

4.3. A focus on the inequality effects of environmental taxation...........................................................19

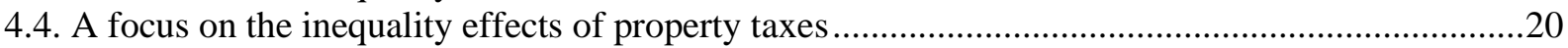

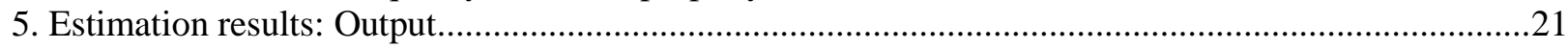

5.1. Effects of tax shifts involving changes in CIT, PIT or VAT rates all considered together .............21

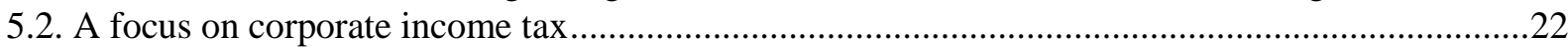

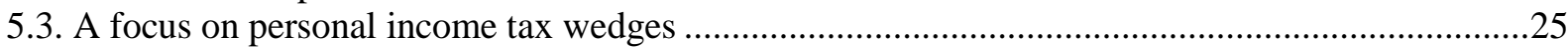

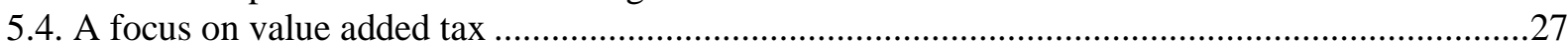

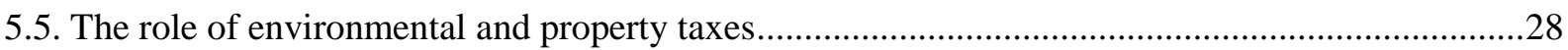

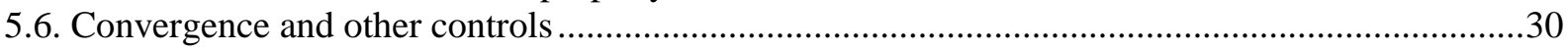

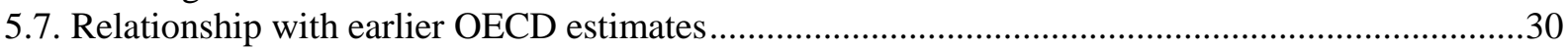

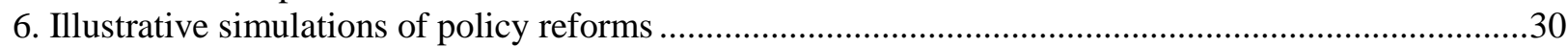

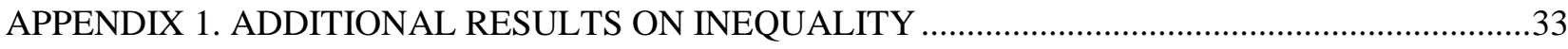

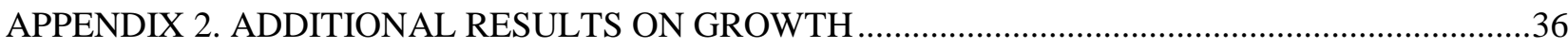

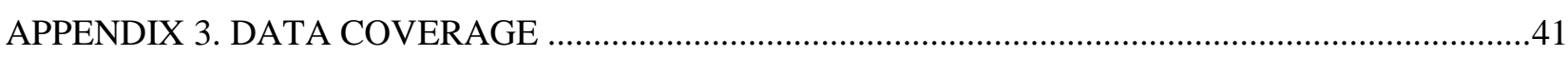

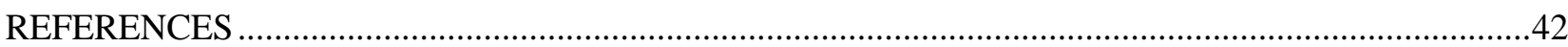

\section{Tables}

1. Summary of average historical effects on income equality and output ...........................................

2. The effect of the average tax wedge on the income distribution .....................................................17

3. The effect of the marginal tax wedge on the income distribution ....................................................17

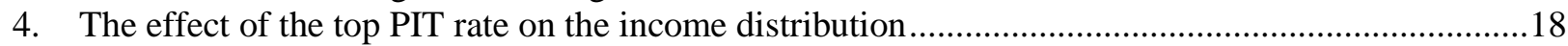

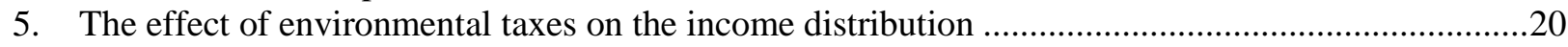

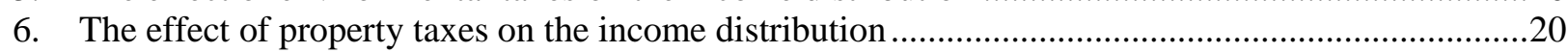

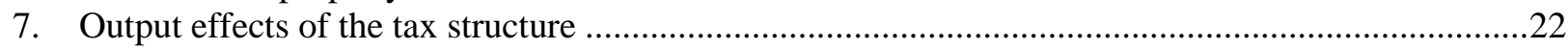

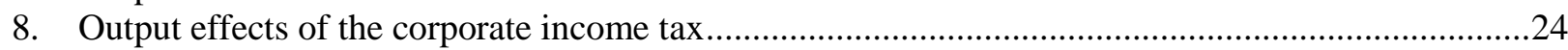

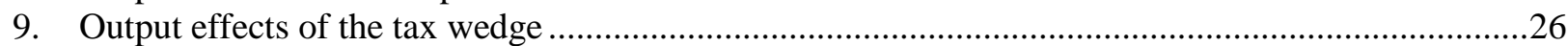

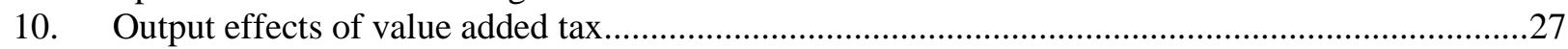

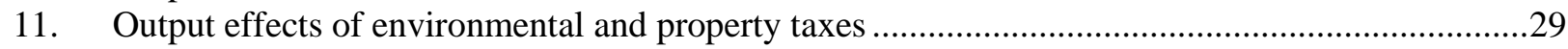


A1.1. The effect of the tax structure on the income distribution ......................................................33

A1.2. The effect of the VAT statutory rate and tax wedge on income distribution ............................33

A1.3. The effect of the effective marginal CIT rate and tax wedge on income distribution ...............34

A1.4. The effect of the top PIT rate on the income distribution, pre-crisis......................................34

A1.5. The effect of the top PIT rate on the income distribution, with a control for underlying primary revenues 35

A1.6. The effect of the average tax wedge on the income distribution: Robustness check with no lead variable 35

A2.1. Growth regressions controlling for the total-tax-GDP ratio: Corporate income tax .................36

A2.2. Growth regressions controlling for the total-tax-GDP ratio: Personal income tax.....................37

A2.3. Growth regressions controlling for the total-tax-GDP ratio: Value added tax ..........................38

A2.4. Growth regressions controlling for the total-tax-GDP ratio: Environmental and property taxes39

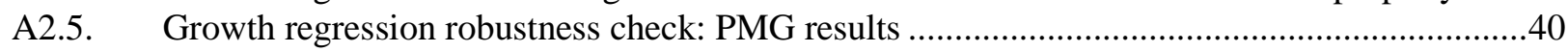

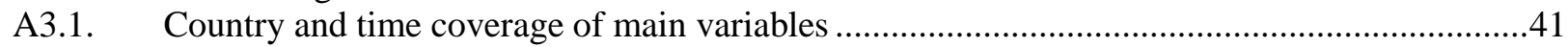

\section{Figures}

1. A simple framework to assess growth and inequality effects.........................................................11

2. Evolution of the effective tax rate by productivity level .............................................................16

3. Stylised share of population that is facing the top marginal tax rate ................................................19

4. Long-term disposable income effects of tax changes .......................................................................

\section{Boxes}

1. Firms at the productivity frontier enjoy lower effective taxation ..............................................16

2. Approximating the relevance of the top marginal PIT rate .........................................................18 


\title{
THE EFFECTS OF THE TAX MIX ON INEQUALITY AND GROWTH
}

\author{
By Oguzhan Akgun, Boris Cournède and Jean-Marc Fournier ${ }^{1}$
}

\section{Introduction and main findings}

1. The present study investigates how the choice of taxes to fund government activities influences the distribution and level of income. It provides a bird's eye view of how major shifts in the tax structure influence the long-term distribution and level of income. The present work estimates effects on semiaggregated income data, which incorporate general-equilibrium feedbacks. ${ }^{2}$

2. The present paper looks at the long-term effects of tax shifts on inequality and output for an unchanged size of government. The focus is structural, abstracting from cyclical effects, and on the tax mix: output and inequality effects of government size were evaluated by Fournier and Johansson (2016) at an earlier stage of the project. The analysis investigates shifts in the tax mix by adjusting rates whenever the necessary data are available. The present work builds on the survey of the literature and existing evidence provided by Johansson (2016). Consequently, the present paper focuses on presenting new empirical results (see Johansson, 2016, and Brys et al., 2016, for more in-depth background on the literature).

3. This study uses econometric analysis to provide estimates of distributional and output effects that can be expected based on the track record in OECD countries. The results from the analysis therefore provide estimates that can feed into assessments of tax reforms, but need to be complemented by the specifics of countries' tax systems, the particular design features of each reform and the particular

1. The authors are members of the OECD Economics Department. The Working Party No. 1 on Macroeconomic and Structural Policy Analysis of the Economic Policy Committee and the Working Party No. 2 on Tax Policy Analysis and Tax Statistics of the Committee on Fiscal Affairs discussed an earlier version of this paper. The authors thank members of the Working Parties and their Chairs MM. Arent Skjaeveland (Finance Ministry of Norway) and Paolo Acciari (Ministry of Economy and Finance of Italy) for their feedback. The authors are indebted to Peter Hoeller, Christian Kastrop and Catherine L. Mann (OECD Economics Department) for their guidance of the project. They also thank David Bradbury, Bert Brys and Giorgia Maffini from the OECD Centre for Tax Policy and Administration, Fabrice Murtin from the Statistics Directorate, Sebastian Barnes, Orsetta Causa, Antoine Goujard and Mikkel Hermansen from the OECD Economics Department for their comments. The authors are indebted to Debra Bloch for statistical assistance and Celia Rutkoski (OECD Economics Department) for editorial support.

2. This study complements other lines of work that look closely at more specific features of tax design that measures covering all main government revenue items across more than thirty countries over two to three decades cannot capture. Two important complementary OECD papers are (a) Brys et al. (2016), who in the spirit of van den Noord and Heady's (2002) study analyse how the design features of tax systems influence social inclusion, and (b) Causa and Hermansen (2017), who use household survey micro-data to evaluate the effects of transfers and taxes on the distribution of household income. They cover the transfer side, where two thirds of redistribution occurs, in a detailed manner and mostly personal income taxes and employees' social security contributions on the tax side. 
economic and other circumstances that shape each situation. All these country and situation-specific characteristics mean that the effects of a given reform can depart from the generally expected effects reported here. The simulation results reported in the paper are thus illustrative. Moreover, the results relate to effects on disposable income: consequently, they do not incorporate impacts of taxation on consumption or other dimensions of welfare such as environmental quality.

4. The main findings emerging from the analysis are:

- Taxes primarily influence redistribution by funding transfers: larger governments reduce inequality more (see also Joumard et al., 2012, Fournier and Johansson, 2016 and Causa and Hermansen, 2017).

- Some taxes (especially those on labour income) nevertheless can have a considerable effect on the distribution of income. For an unchanged size of government spending or revenue:

- A higher labour tax wedge in the upper half of the income distribution is linked with lower relative disposable incomes in this upper half (by comparison with the mean) and higher ones in the bottom half of the distribution.

- Higher top marginal income tax rates or lower thresholds for applying them reduce relative disposable incomes at the higher end of the income distribution.

- Greater reliance on environmental taxes is associated with greater disposable income inequality.

- Revenue mixes that rely more on inheritance and wealth taxes are linked with lower levels of disposable income inequality.

- Recurrent taxes on immovable property do not appear to significantly influence income inequality.

- VAT or CIT rate changes that are part of tax shifts leaving government size fixed do not significantly influence the distribution of disposable income. VAT reforms may nevertheless affect the distribution of consumption. In the absence of cross-country data on the distribution of consumption, this effect could not be tested.

- In line with the channels suggested by the literature and earlier OECD work, the investigations into the output effects of the tax mix confirm that some taxes are more distortive than others. For an unchanged size of government (measured by spending or revenue):

- Higher marginal effective rates of corporate income taxation are linked with significantly lower long-term output levels.

- Higher marginal labour tax wedges on above or below average income earners appear to reduce long-term output. By contrast, the tax wedge at average wage income does not appear to have a large effect on long-term output. Taken together, these results mean that:

- Greater progressivity at lower-middle income levels, in the form of lower tax wedges on low income earners, is associated with higher long-term output;

- Greater progressivity in the upper half of the income distribution, in the form of higher tax wedges on above average income earners, is linked with lower long-term output.

- Changes in the standard VAT rate have no significant effects on long-term growth. 
- More reliance on recurrent taxes on immovable property is typically followed by higher longterm output. This confirms theoretical insights and earlier evidence that land-based taxes, which are a substantial part of recurrent taxes on immovable property, entail few distortions.

- Greater reliance on inheritance and gift taxes, as well as other one-off property taxes, also appears to be output-enhancing by comparison with other revenue sources. Transaction taxes have no significant effects.

- By contrast, taxes on net wealth are found to be associated with lower output levels, in line with the literature on their distortive effects.

- The inequality and output results can be combined to simulate what tax shifts imply for the absolute level of disposable income of each quintile. It should be noted that the findings relate to output and disposable income and thus do not cover other well-being dimensions, such as environmental quality. Overall, the findings highlight that reforming the tax mix can deliver winwin changes, substantially influence only one outcome or involve trade-offs depending on the instrument (Table 1):

Table 1. Summary of average historical effects on income equality and output

\begin{tabular}{|c|c|c|c|c|}
\hline $\begin{array}{l}\text { Adjusting other taxes, while keeping government } \\
\text { size constant. Effects of: }\end{array}$ & $\begin{array}{l}\text { Equality: } \\
\text { Poor/rich }\end{array}$ & $\begin{array}{c}\text { Average } \\
\text { output }\end{array}$ & $\begin{array}{l}\text { Income } \\
\text { of the poor }\end{array}$ & $\begin{array}{l}\text { Income } \\
\text { of the rich }\end{array}$ \\
\hline Lower tax wedge on upper-middle incomes & : & ;) & ;: & $(-)$ \\
\hline Lower tax wedge on lower-middle incomes & (;) & (:) & $(-)$ & ;) \\
\hline Reduction in the effective CIT rate & n.s. & (:) & (:) & (:) \\
\hline Change in standard VAT rate & n.s. & n.s. & n.s. & n.s. \\
\hline More use of environmental taxes & : & n.s. & : & (;) \\
\hline $\begin{array}{l}\text { More use of recurrent property taxes on } \\
\text { immovable property }\end{array}$ & n.s. & (:) & (:) & ;) \\
\hline More use of inheritance taxes & (;) & ;) & $(\ddot{)}$ & ;) \\
\hline Cut in taxes on net wealth & 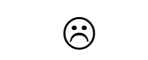 & $\ominus$ & (:) & $(-)$ \\
\hline
\end{tabular}

Note: Output results relate to long-term GDP per capita and income results to long-term levels of household disposable income (adjusted by household size). The poor are defined as the bottom income quintile and the rich as the top one. The sign of the change in tax (increase or decrease) is chosen so that the average output effect is positive, to facilitate comparisons. Output changes can be considered equivalent to changes in average household disposable income (see Hermansen et al., 2016). The equality effect reflects the difference between the effect on the poor and the effect on the rich. Other dimensions of well-being than income, such as effects on consumption choices or environmental quality, do not enter this assessment. PIT is personal income tax, CIT is corporate income tax and VAT is value added tax. For a given instrument, the size of the smiley reflects the relative size of the effect across the different outcomes.

5. The paper discusses in Section 2 what kind of effects the literature suggests should be expected. It then presents the conceptual framework for the analysis, methodology and data in Section 3. Section 4 details the results obtained for the effects of the tax mix on the income distribution while Section 5 presents the findings for long-term output. Section 6 provides simulations of the effects of illustrative tax reforms, which combine the inequality and output results to obtain reform effects by income quintile. 


\section{Anticipated results: What do existing studies tell? ${ }^{3}$}

6. A vast domain of the economic literature has studied optimal taxation from a conceptual perspective (see for instance Mirrlees, 1986; Kaplow, 2008; Myles, 2009a). This literature links the tax structure to welfare and hence encompasses both growth and equity considerations. A very broad thread running through theoretical studies, especially the literature inspired by Mirrlees (1971), is the finding that high marginal rates of taxation on high-productivity workers and providers of capital hurt prosperity and reduce welfare. The more recent literature has questioned this earlier viewpoint, largely because of the uncertainty attached to predicting tax-induced changes in behaviour, underlining the importance of empirical estimates of tax effects (see in particular the review by Piketty and Saez, 2013). On this basis, the current study takes an empirical perspective (of which the framework is laid out in the next section) and the brief literature overview presented here focuses on empirical findings.

\subsection{Income inequality}

7. The personal income tax is the most important tax instrument to redistribute income (see for instance OECD, 2011, and Joumard et al., 2012 for descriptions of the direct redistributive effect of taxes). Redistribution objectives can directly feed into the design of the personal income tax (PIT) via its progressivity. It is also a large source of tax revenue. By contrast, other tax instruments are expected to have a smaller overall redistributive effect. Property taxes can be designed to target high income households, but it typically is a much smaller tax than PIT (Bloch et al., 2016).

8. By contrast, other taxes have more indirect links with household disposable income. Who ultimately pays corporate income tax (CIT) is difficult to pin down from either a conceptual or an empirical perspective (Mirrlees et al., 2011). In a closed economy setting, theory indicates that the share of corporate income tax that ultimately falls on capital compensation depends on parameters such as the elasticity of substitution between labour and capital (Harberger, 1962). In open economies, the mobility of capital implies that wages bear a share of the burden of corporate income tax that can rise from 0 to $100 \%$ of CIT receipts as capital becomes more mobile (Mutti and Grubert, 1985). Faced with theoretical uncertainty, practical policy simulations have excluded corporate income tax from distributional analysis (Inchauste and Lustig, 2017) or used a wide range of assumptions: for instance, for a relatively closed economy such as the United States, the share of the CIT burden borne by wages ranges from $0 \%$ in Piketty and Saez (2004) to 18\% in Cronin et al. (2013) to above 70\% (Randolph, 2006).

9. For consumption taxes, the ultimate burden of the tax depends on whether people consume different items depending on the income group to which they belong. Such differences in the consumption basket will influence the extent to which certain income groups will be more exposed to a change in consumption tax. This suggests that, when possible, assessing distributional effects at the consumption expenditure stage, rather than the income stage, as this provides a better measure of lifetime distributional effects (OECD, 2014a).

10. Furthermore, the ratio of consumption to income, which typically decreases as income rises, can also have implications for the distribution of the consumption tax burden. This channel, which stems from differences in the consumption-saving split, is however conceptually less relevant than the previous one, which comes from differences in consumption baskets, because savings are ultimately spent for consumption (if not by the saver, by the heirs).

3. This section draws on Johansson (2016). 
11. Against this background, simulation studies have frequently been used to quantify the direct impact of tax changes on the distribution of income and expenditure. A recent extensive OECD (2014a) microsimulation-based study found that:

- Value added taxes are generally slightly regressive when measured against income but either proportional or even moderately progressive when measured against expenditure; and

- Excise tax burdens are almost always regressive when measured against income, though this effect is attenuated when measured against expenditure (because the denominator, expenditure, makes up a smaller share of income at high than at low income levels).

12. Micro-simulations of a frequently considered reform, shifting the tax mix away from income towards value added, typically indicate that such a shift would be regressive (e.g. Pestel and Sommer, 2017; Decoster et al., 2011). The main reason is that, while consumption and recurrent property taxes are close to proportional, personal income taxes are typically fairly progressive. Some studies have, however, highlighted that after accounting for labour-supply adjustments, the adverse distributional impact is smaller when focussing cuts on payroll taxes, thanks to increased work incentives (Pestel and Sommer, 2017).

13. There can also be substantial differences between how tax-and-transfer programmes redistribute income among the population at a given point in time and within a cohort over its lifetime. A recent simulation study suggests that US tax-and-transfer programmes are considerably more redistributive when considering consumption within a cohort over its lifetime rather than disposable income across the population at a given time (Auerbach et al., 2016).

\subsection{Growth}

14. By comparison with the vast theoretical literature on the topic, only a relatively narrow body of empirical research has looked at the growth effects of the tax mix (Johansson, 2016). Nonetheless, a number of empirical studies support the hypothesis that distortive taxes hold back growth more than others (Kneller et al., 1999; Gemmell et al., 2011 and 2014; Drucker et al., 2017).

15. Corporate and personal income taxes are considered more distortionary than consumption or recurrent property taxes. A past OECD study using a standard empirical growth model confirmed this ranking for a panel of OECD countries (Arnold et al., 2011). These results imply that, for a given level of total government receipts, shifting the revenue mix away from more towards less distortionary taxes, such as by reducing corporate and personal income taxation and raising recurrent property and consumption taxes, could boost GDP growth.

- The main underlying channel is that taxes on corporate or personal income reduce incentives to raise supply through capital accumulation or productivity enhancements (Galindo and Pombo, 2011; Myles, 2009b; Schwellnus and Arnold, 2008; Vartia, 2008).

- By contrast, land taxes have no disincentive effects, since land supply is fixed (Blöchliger, 2015).

- Consumption taxes entail some disincentive effects, which are generally found to be weaker than those of income taxes in the empirical literature (Johansson, 2016).

16. Studies focusing on both OECD and non-OECD countries established broadly similar results. Acosta-Ormaechea and Yoo (2012) confirmed that property and consumption taxes are more growthfriendly than income taxes (particularly personal income taxes). Likewise, McNabb and LeMay-Boucher (2014) and Drucker et al. (2017) found that reducing the share of income taxes in the revenue mix would raise GDP growth. 


\section{Framework, data and methodology}

\subsection{Framework}

17. The analysis uses an empirical framework nesting output effects to assess the effects of the tax structure on the distribution of disposable income as in Fournier and Johansson (2016) (Figure 1). The investigations look into the effect of shifts in the tax structure, that is to say policy changes that keep the size of government constant. Primary spending measures the size of government in the baseline estimates: the tax policy changes considered here thus have no spending implications. Each baseline estimate is rerun by controlling for total taxes instead of government spending.

- The first step addresses inequality effects of tax shifts. Each regression in this step estimates how a shift in the tax structure influences income by quintile (Arrow 1), while controlling for the effect of average output on this quintile's income (Arrow 2).

- Each regression in the second step gauges the output effect of a tax shift (Arrow 3).

Figure 1. A simple framework to assess growth and inequality effects

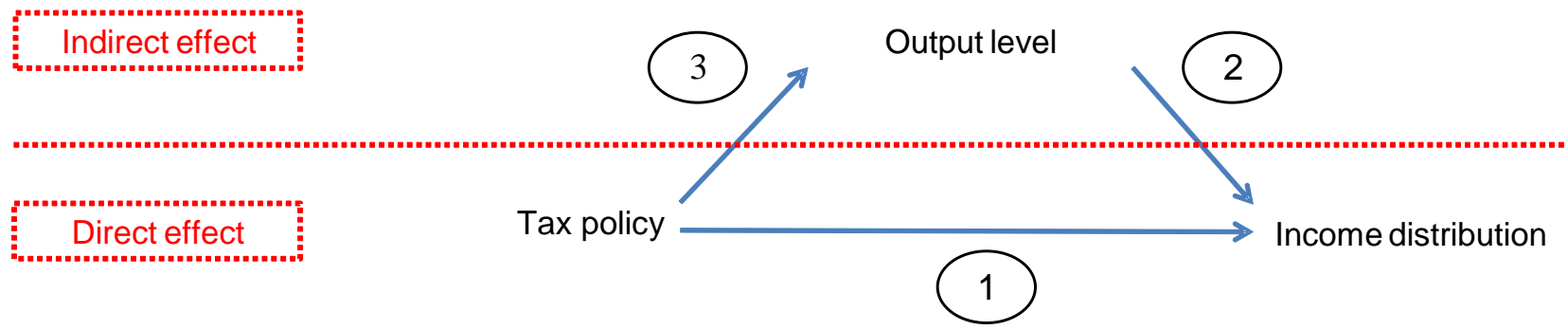

18. Putting together Arrows 1 and 2 (from the inequality regression) and Arrow 3 (from the output estimation) allows calculating the total effect of tax policy changes on the income distribution, including effects that transit through the level of output. In practice, however, the estimates show that, for a typical OECD country, output changes have broadly uniform effects on income levels across the distribution (see the top row in Tables 2-7 below). Consequently, the relative effects of tax changes across quintiles estimated in Arrow 1 are not significantly affected by the inclusion of the output-related effects estimated in Arrows 2 and 3.

19. The use of country-level data allows capturing general equilibrium effects on the disposable income distribution. This can be illustrated with a simple example in which an increase in the top marginal rate has a two-pronged direct effect and an indirect one on disposable income.

- The direct effect (Arrow 1 above) comes from two sources:

- A higher top marginal rate will take more money out of the disposable income of top earners.

- Top earners' change in work and investment decisions following the increase in the top marginal rate.

- An indirect effect (Arrows 2 and 3 above) will materialise if this tax hike implies a reduction in the productivity gains generated by highly-skilled workers that flow across the population. The growth regression (Arrow 3) captures the average indirect effect. The average income control in the inequality regression (Arrow 2) captures the distributional consequences of changes in average income. Strictly speaking, closing the diagram requires an estimate of the elasticity of average household disposable income to output per capita: the study for the Working Party by Hermansen et al. (2016) indicates that, in the long run, this elasticity is equal to one. 
20. Combining such income distribution (Arrows 1 and 2) with growth results (Arrow 3) therefore enables estimating a general equilibrium effect that takes account of behavioural responses and economywide feedback, as in Fournier and Johansson (2016). The empirical studies at the individual level in Causa and Hermansen (2017) provide a complementary perspective: they use much more information to uncover tax and transfer changes at the individual level, which allows a more granular description of the first part of the direct effects of tax and transfer schemes. At the same time, by nature of the data, they cannot gauge indirect effects. They also focus on taxes and transfers for which the household surveys provide information (personal income taxes, employee social security contributions and cash transfers).

21. This framework comes with limitations that are intrinsic to econometric analyses using long time series of indicators that are comparable across countries. Indicators of this nature capture only part of the tax design (e.g. a few statutory or effective rates, aggregate receipts from a given tax) and exclude important items (such as the hundreds of pages defining how the tax base is calculated and which activities may benefit from preferential treatment or exemptions). By nature, these detailed items are countryspecific and not amenable to integration in indicators that can be compared across countries. The present framework of analysis is therefore complementary to country-specific analysis that can delve into these more detailed items. It adds to such country-level analyses the insights for the distributional and output effects that can be gleaned from OECD countries' decades of experience with changes in the headline tax instruments that cross-country indicators can capture.

\subsection{The inequality regressions}

22. The income variables in the inequality regressions are the disposable income level by quintile for the working-age population from the OECD Income Distribution Database (IDD). This database is built on household level equivalised (i.e. adjusted for household size) disposable income reported in household surveys. Interpolated data are not used for the dependent variable to avoid artificially narrowing the standard errors, but they are used for the explanatory variables.

23. The effect of tax policy on the income distribution is estimated with country-level panel data regressions in which the level of income at a given quintile depends on the average income level and a set of explanatory variables. These equations are cointegration relationships between average income and the income of a given quintile, which are not stationary. The estimation method used in the baseline approach relies on the fixed effect panel least squares estimator. Following Phillips and Loretan (1991), Saikkonen (1991) and Stock and Watson (1993), one lead of the first difference of the non-stationary explanatory variable is added to address the feedback effect of the dependent variable (income by quintile) on this nonstationary explanatory variable (mean income) ${ }^{4}$ This approach is similar to that used by Akgun and Dougherty (2018) and quite close to Hermansen et al. (2016) and Fournier and Johansson (2016). The specification is as follows:

$$
y_{c, t}^{q}=\alpha y_{c, t}^{m}+\delta_{1} \Delta y_{c, t+1}^{m}+\delta_{2} \Delta y_{c, t}^{m}+\delta_{3} \Delta y_{c, t-1}^{m}+\beta_{1} S_{c, t-1}+\beta_{2} T_{c, t-1}+u_{c}+v_{t}+\varepsilon_{c, t}
$$

where $y_{c, t}^{q}$ is the level of disposable income of the $\mathrm{q}^{\text {th }}$ quintile in country $c$ at year $t, y_{c, t}^{m}$ the mean disposable income, $S_{c, t}$ the size of government measured by the cyclically-adjusted government primary spending to GDP ratio, $T_{c, t}$ is a vector of tax policy indicators modelling the tax mix, $u_{c}$ and $v_{t}$ are country and year fixed effects and $\varepsilon_{c, t}$ is idiosyncratic noise. Checks have shown that results with Gini coefficients are coherent with quintile results.

4. The insertion of the short-term terms has hardly visible effects on the results (see Table A1.5 for an example of a robustness check without the lead term). 
24. The regression uses the following tax policy indicators:

1. For the taxation of personal income, the analysis is conducted with effective tax wedges at different income levels taken from OECD (2017) and the top marginal rate of PIT. The inequality analysis uses average effective rates, because they are tightly related to the amounts of money that taxes on personal income take away from market income at different points of the distribution. The growth analysis mainly uses marginal effective rates, because they are the main drivers of labour supply and saving decisions. The work also considers the top marginal rate of PIT and the extent to which it is used (see Box 1).

2. For CIT, marginal effective tax rates from CBT (2016) measure incremental taxation on a "representative" investment. Effective CIT rates have been shown to have greater influence on economic decisions than statutory ones (Ederveen and de Mooij, 2003).

3. For VAT, in the absence of measures of effective marginal rates accounting for reduced rates and exemptions, the analysis is based on standard rates from the OECD Tax Database.

4. For environmental and property taxes, the ratios of government receipts to GDP from OECD (2016a) are used for lack of cross-country data on tax rates. The classification of the data follows Bloch et al. (2016).

25. The tax indicators to the extent possible enter the equation as a wide group so as to cover shifts within the tax system in a way that accounts for correlations among tax indicators. In practice, however, data availability limits the number of tax indicators that can enter the equation simultaneously without overly shrinking sample size and preventing identification (see Appendix Table A3.1 for data coverage). The regressions reported below (for inequality as well as for output) therefore start by considering a group of tax policy indicators covering the main broad tax categories before focussing on individual taxes separately.

26. The regressions control for government size, because the investigations look at the effects of shifts in tax structure rather than changes of the role of government in the economy. The size of government is measured by the ratio of primary public spending, rather than revenue, to GDP for two reasons. First, this choice allows putting together the present estimates with Fournier and Johansson's (2016) for the spending side in a consistent manner when evaluating policy packages. Second, government spending encompasses revenues and borrowing which can be assimilated to future taxation. Alternative regressions with tax revenue have also been run and illustrate that the results do not depend much on this choice (e.g. Table A1.5, additional regressions with tax revenue are available on request).

27. Reported standard errors are robust to arbitrary levels of heteroskedasticity and autocorrelation (HAC). To correct for heteroskedasticity, each error term is allowed to have its own variance, which is the most general option, as in White (1980). To correct for autocorrelation, Newey and West's (1987) estimates are reported using the Bartlett kernel with a bandwidth of 6 . The same bandwidth is used by Kao et al. (1999) in a similar sized sample.

\subsection{The growth regressions}

28. The methodology used to estimate growth effects closely follows the strategy implemented for the spending mix (Fournier and Johansson, 2016). In line with Mankiw et al. (1992), the long-term level of GDP depends on physical and human capital accumulation. This long-term relationship is embedded in a convergence equation where the potential growth rate of GDP per capita depends on the past potential GDP per capita level, production factors, government size, tax indicators and other factors influencing growth. This empirical strategy identifies effects on the level of GDP. However, convergence is relatively 
slow (with a half-life of 10 to 17 years), so that in practice the level effects are attained by temporary yet persistent growth effects.

29. The convergence equation below estimates the effects of the tax structure on potential output per capita. Its specification parallels Fournier and Johansson's (2016) for the output effects of spending, so that the two sets of results can ultimately be combined in a consistent manner to simulate the effects of public finance reforms:

$\Delta y_{c, t}=\gamma y_{c, t-1}+\alpha_{1} i_{c, t-1}+\alpha_{2} h_{c, t-1}+\alpha_{3} l_{c, t-1}+\delta_{1} \Delta i_{c, t}+\delta_{2} \Delta h_{c, t}+\delta_{3} \Delta l_{c, t}+\alpha_{4} m_{c, t-1}+\alpha_{5} \pi_{c, t-1}+$ $\alpha_{6} d_{c, t-1}+\alpha_{7} o_{c, t-1}+\alpha_{8} q_{c, t-1}+\beta_{1} S_{c, t-1}+\beta_{2} T_{c, t-1}+u_{c}+v_{t}+\varepsilon_{c, t}$ where

- $y_{c, t}$ stands for the logarithm of potential output per capita from the OECD Economic Outlook of November 2016 (OECD, 2016).

- $i_{c, t}$ for the logarithm of the cyclically-adjusted share of investment in GDP from OECD (2016).

- $\quad h_{c, t}$ for human capital investment measured by the change in the number of years of schooling of the population over 14 from the OECD long-term baseline projections (OECD, 2014b) based on Barro and Lee (2013).

- $\quad l_{c, t}$ for trend growth of the working-age population from OECD (2014b).

- $m_{c, t}$ for market potential, which is the aggregate of partner countries' GDP divided by distance, following Krugman (1992). This measure is preferred to the trade over GDP ratio because it does not depend on taxation and hence does not capture any indirect effects. Gravity models show GDP and distance are strong determinants of trade and foreign direct investment (e.g. Fournier, 2015).

- $\pi_{c, t}$ for the consumer price inflation rate from OECD (2016).

- $\quad d_{c, t}$ for private-sector debt from the World Bank Global Financial Development Database.

- $o_{c, t}$ for the old-age dependency ratio (i.e. the share of people aged 65 and more in the population) from the OECD long-term scenario database.

- $\quad q_{c, t}$ for governance quality, a composite measure based on World Bank indicators, updated by Akgun et al. (2017).

- $\quad S_{c, t}$ for the cyclically-adjusted ratio of government spending to GDP based on OECD (2016) data.

- $T_{c, t}$ for a vector of tax indicators (see above).

- $\quad u_{c}$ for country fixed effects. One nuance with Fournier and Johansson (2016) is that the present set of estimates systematically includes country fixed effects, which allow capturing all national circumstances that do not change over time.

- $v_{t}$ for yearly dummies.

- $\varepsilon_{c, t}$ for the error term. 
30. As for inequality, the regression controls for the size of government using the ratio of government spending to GDP rather than taxes to allow combining the results with Fournier and Johansson's (2016) and because current borrowing implies future taxes. Nevertheless, the regressions have been re-run with total tax revenue as a control to check that the estimated coefficients indeed correspond to an effect of the tax mix. The results obtained when controlling for government spending are very robust to switching to total tax revenue (Table 7, Columns 3-4; Tables A2.1-4).

31. Reported standard errors are robust to arbitrary heteroskedasticity and autocorrelation (HAC) as in the inequality regressions. Assuming $\gamma<0$, HAC standard errors will overestimate the variances in this model: the tests are conservative. Non-HAC standard errors can underestimate the variances, which is why HAC standard errors are preferred.

32. The sample comprises all OECD countries, which provide internationally comparable data on tax rates and receipts. This means a considerably larger sample than Gemmell et al. (2015) used. Another difference with Gemmell et al. (2015), who also use Mankiw et al.'s (1992) error-correction productionfunction framework, is that the present study explains potential growth, while Gemmell et al. (2015) use actual growth. Using potential growth presents the benefit of considerably alleviating the risk that longterm effects may accidentally be spuriously identified because of cyclical co-movement. This benefit most likely outweighs the drawbacks of potential output measurement errors. Potential output measurement errors mainly affect the end points in real time, as explained by Orphanides and van Norden (2002) among others. Moreover, the use of potential growth, which does not exhibit as much variation as actual growth, makes the estimation more demanding and therefore the results more robust.

\section{Estimation results: Inequality}

33. Direct analysis of tax and transfer systems indicate that, on the tax side, personal income taxes play the largest role in shaping inequality and that other tax instruments (such as VAT) may also play a role albeit a more limited one (Joumard et al., 2012, Causa and Hermansen, 2017). These descriptive findings are further validated here by a set of regressions showing that tax wedges play the largest role in shaping disposable income inequality.

\subsection{Inequality effects of tax shifts involving changes in CIT, PIT or VAT rates all considered together}

34. A first set of regressions uses four key tax indicators: the statutory VAT rate, the effective marginal CIT rate and the average tax wedge at $67 \%$ and at $167 \%$ of average income (Table A1.1). The results confirm that there is no strong effect of VAT and CIT on the disposable income distribution structure, while the tax wedge can affect this distribution. As variable selection is a delicate exercise that cannot be resolved with a single step, the effect of VAT and CIT is further checked with two sets of regression. One is made with these two tax wedges and the VAT standard rate, the second one with these two tax wedges and the effective marginal CIT rate: both the VAT and CIT indicators are insignificant along the income distribution (Table A1.2 and A1.3). Insignificant results mean that the effects are relatively small compared to the effect of personal income taxation, but they may still exist and further research with much more detailed data may shed a light on these small effects. In sum, any aggregate effects of VAT and CIT on the disposable income distribution are too small to be observed here.

35. While tax shifts towards VAT have no statistically significant link with disposable income inequality, they might potentially have distributional consequences at the stage of consumption. Microsimulation studies on European data, however, indicate that the share of VAT payments in total consumption is proportional or even slightly progressive (Decoster et al., 2010; Pestel and Sommer, 2013). In addition, Caspersen and Metcalf (1993) who go beyond annual income inequality to consider lifetime income show that VAT can be proportional to slightly progressive. 
36. No statistically significant effect on the income distribution appears for CIT either. Further checks with the World Wealth and Income database that focuses on top income pre-tax earnings confirms with a limited sample size that there is no significant link between the effective corporate income tax rate and earnings. The downward trend in the amount of corporate taxes paid by the highest productivity relative to other firms (Box 1) might conceivably have contributed to weakening any potential distributional impacts of CIT. Between-firm pay differences, which are related to productivity differentials, indeed are important contributors of income inequality (Furman and Orszag, 2015; Song et al., 2016).

37. The estimates show a broadly uniform link between incomes at the mean and in the five quintiles. A one per cent increase in mean income is associated with a one per cent increase in the income of each quintile (coefficient associated with the logarithm of mean income in Tables 2 to 6).

\section{Box 1. Firms at the productivity frontier enjoy lower effective taxation}

Firm-level data show that the burden of taxation has been diverging between top productivity performers ("frontier firms") and other firms over the past decade (Figure 2). This analysis uses firm-level financial reports from the ORBIS database for France, Germany, Italy, Korea, the United Kingdom and Sweden (countries that have been selected for the quality of coverage in the ORBIS database). Frontier firms are defined as the companies with the highest level of productivity in each sector and for each year according to Gal's (2013) multifactor productivity estimates. The amount of taxes reported in the ORBIS database lumps together all tax payments made during the year; this amount includes CIT and property taxes paid by firms but not labour-related contributions. For the analysis this value is normalised by pre-tax earnings (defined as the sum of operating and financial profits). The resulting indicator represents the cash effective tax rate that each firm paid during the fiscal year. It is an ex-post measure of taxation, which is useful when considering tax differences across firms (Johansson et al., 2017).

Figure 2. Evolution of the effective tax rate by productivity level

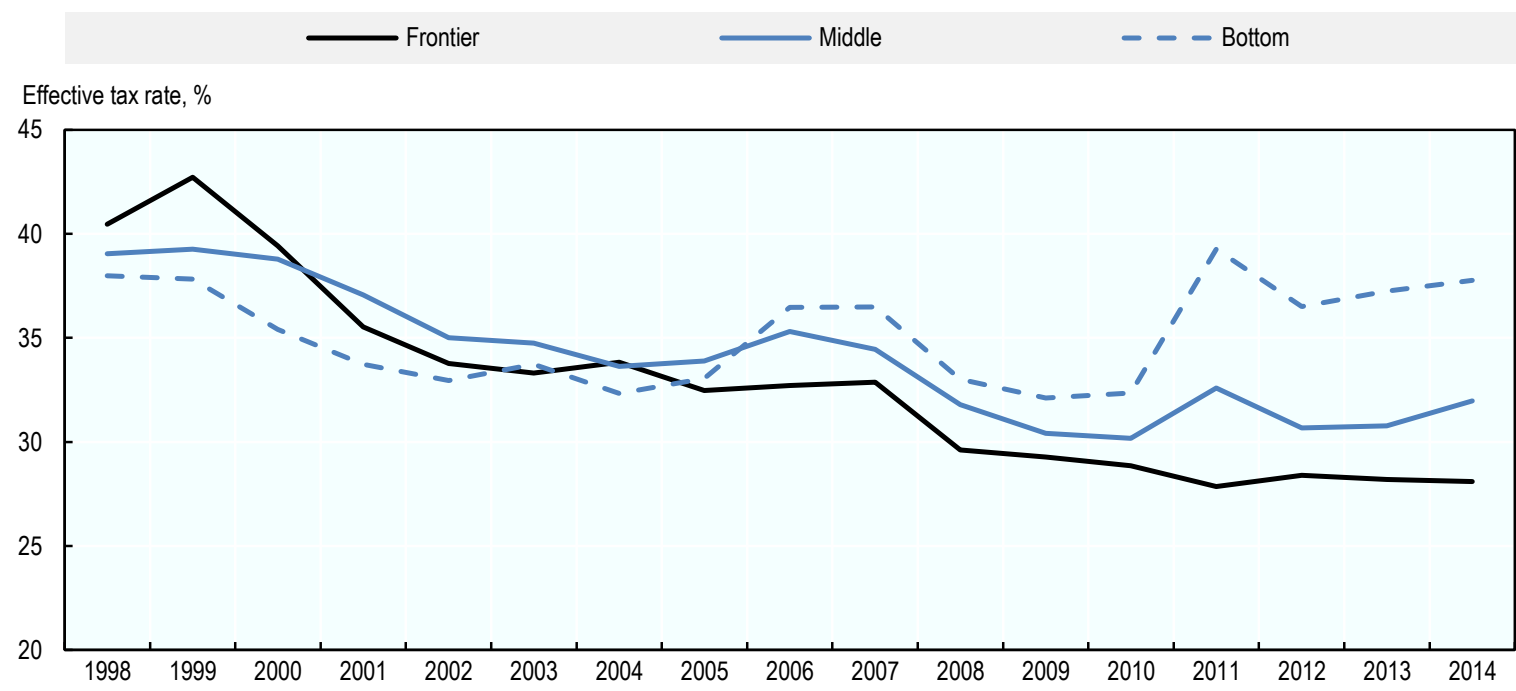

Note: Frontier firms are defined as firms in the top $5^{\text {th }}$ percentile of the multifactor productivity distribution for each industry-year. Bottom firms are firms in the bottom $25^{\text {th }}$ percentile of the productivity distribution for each industry-year. The middle group consists of the remaining firms.

Source: Bartolini, D. (2018), "Firms at the Productivity Frontier Enjoy Lower Effective Taxation", OECD Economics Department Working Papers, forthcoming. 


\subsection{A focus on the inequality effects of personal income tax and the labour tax wedge}

38. Broad measures of the tax wedge provide evidence of the redistributive effect of the tax and transfer system. The OECD tax wedge indicator published in Taxing Wages includes personal income tax and social security contributions minus cash benefits. The average tax wedge for a single at $67 \%$ and $167 \%$ of average earning without a child is considered here (Table 2). As anticipated, average rates (Table 2) have a larger inequality reducing effect than the marginal rates (Table 3): the total amount of money taken away from a taxpayer is what matters most for redistribution. The estimates show that a higher tax wedge for those at $167 \%$ of average earnings is associated with a lower income at the $4^{\text {th }}$ quintile, and a higher income at the lower end of the income distribution. By contrast, the tax wedge for those at $67 \%$ of average earnings, which targets low-income earners, increases inequality.

Table 2. The effect of the average tax wedge on the income distribution

\begin{tabular}{|c|c|c|c|c|c|}
\hline Dependent variable & $\ln \left(\right.$ income $\left.^{q 1}\right)$ & $\ln \left(\right.$ income $\left.^{q 2}\right)$ & $\ln \left(\right.$ income $\left.^{q^{3}}\right)$ & $\ln \left(\right.$ income $\left.^{q 4}\right)$ & In income $^{q^{5}}$ ) \\
\hline $\ln \left(\text { income }^{\text {mean }}\right)_{t}$ & $\begin{array}{l}1.19^{* * *} \\
(0.095)\end{array}$ & $\begin{array}{l}1.01^{* \star *} \\
(0.045)\end{array}$ & $\begin{array}{l}0.94^{* * *} \\
(0.030)\end{array}$ & $\begin{array}{c}0.96^{* * *} \\
(0.019)\end{array}$ & $\begin{array}{l}1.01^{* \star *} \\
(0.048)\end{array}$ \\
\hline$\Delta \ln \left(\text { income }^{\text {mean }}\right)_{t+1}$ & $\begin{array}{l}0.23^{*} \\
(0.12)\end{array}$ & $\begin{array}{c}0.056 \\
(0.056)\end{array}$ & $\begin{array}{l}-0.047 \\
(0.040)\end{array}$ & $\begin{array}{l}-0.025 \\
(0.033)\end{array}$ & $\begin{array}{l}-0.022 \\
(0.063)\end{array}$ \\
\hline$\Delta \ln \left(\text { income }^{\text {mean }}\right)_{t}$ & $\begin{array}{l}-0.11 \\
(0.073)\end{array}$ & $\begin{array}{l}-0.087^{\star *} \\
(0.038)\end{array}$ & $\begin{array}{l}-0.00017 \\
(0.026)\end{array}$ & $\begin{array}{r}0.046^{*} \\
(0.027)\end{array}$ & $\begin{array}{c}0.015 \\
(0.038)\end{array}$ \\
\hline$\Delta \ln \left(\text { income }^{\text {mean }}\right)_{\mathrm{t}-1}$ & $\begin{array}{l}-0.10 \\
(0.12)\end{array}$ & $\begin{array}{l}-0.16^{* \star *} \\
(0.055)\end{array}$ & $\begin{array}{l}-0.026 \\
(0.045)\end{array}$ & $\begin{array}{l}-0.047 \\
(0.032)\end{array}$ & $\begin{array}{l}0.11^{* *} \\
(0.057)\end{array}$ \\
\hline $\begin{array}{l}\text { Underlying } \\
\text { primary spending }\end{array}$ & $\begin{array}{l}0.043 \\
(0.10)\end{array}$ & $\begin{array}{l}-0.012 \\
(0.058)\end{array}$ & $\begin{array}{l}-0.11^{* *} \\
(0.049)\end{array}$ & $\begin{array}{l}-0.047 \\
(0.039)\end{array}$ & $\begin{array}{c}0.062 \\
(0.068)\end{array}$ \\
\hline $\begin{array}{l}\text { Average tax wedge } \\
(67 \% \text { mean income) }\end{array}$ & $\begin{array}{l}-0.46^{*} \\
(0.25)\end{array}$ & $\begin{array}{l}-0.23^{*} \\
(0.12)\end{array}$ & $\begin{array}{l}-0.014 \\
(0.081)\end{array}$ & $\begin{array}{c}0.049 \\
(0.066)\end{array}$ & $\begin{array}{l}0.13 \\
(0.14)\end{array}$ \\
\hline $\begin{array}{l}\text { Average tax wedge } \\
\text { (167\% mean income) }\end{array}$ & $\begin{array}{l}0.61^{* * *} \\
(0.16)\end{array}$ & $\begin{array}{c}0.35^{* * *} \\
(0.095) \\
\end{array}$ & $\begin{array}{l}-0.0093 \\
(0.090)\end{array}$ & $\begin{array}{l}-0.15^{\star \star} \\
(0.071)\end{array}$ & $\begin{array}{l}-0.18 \\
(0.12)\end{array}$ \\
\hline $\begin{array}{l}\text { Observations } \\
\mathrm{R}^{2}\end{array}$ & $\begin{array}{c}285 \\
0.702\end{array}$ & $\begin{array}{l}285 \\
0.880\end{array}$ & $\begin{array}{l}285 \\
0.940\end{array}$ & $\begin{array}{l}285 \\
0.965\end{array}$ & $\begin{array}{c}285 \\
0.893\end{array}$ \\
\hline
\end{tabular}

Note: The adjusted $\mathrm{R}$ squared does not incorporate the effect of country and year fixed effects. Asterisks $\left({ }^{*},{ }^{* *},{ }^{* * *}\right)$ indicate the significance level $(10 \%, 5 \%, 1 \%)$ of the coefficients. Standard errors are robust to arbitrary heteroskedasticity and autocorrelation (HAC). See Appendix Table A3.1 for data coverage.

Table 3. The effect of the marginal tax wedge on the income distribution

\begin{tabular}{|c|c|c|c|c|c|}
\hline Dependent variable & $\ln \left(\right.$ income $\left.^{q^{1}}\right)$ & $\ln \left(\right.$ income $\left.^{q^{2}}\right)$ & $\ln \left(\right.$ income $\left.\mathrm{q}^{\mathrm{q}}\right)$ & $\ln \left(\right.$ income $\left.^{q 4}\right)$ & $\ln \left(\right.$ income $\left.\mathrm{q}^{\mathrm{a}}\right)$ \\
\hline $\ln \left(\text { income }^{\text {mean }}\right)_{t}$ & $\begin{array}{l}1.22^{* \star *} \\
(0.093)\end{array}$ & $\begin{array}{l}1.02^{\star * \star} \\
(0.042)\end{array}$ & $\begin{array}{l}0.94^{* * *} \\
(0.028)\end{array}$ & $\begin{array}{l}0.97^{* * *} \\
(0.017)\end{array}$ & $\begin{array}{l}1.00^{* * *} \\
(0.043)\end{array}$ \\
\hline$\Delta \ln \left(\text { income }^{\text {mean }}\right)_{t+1}$ & $\begin{array}{l}0.24^{*} \\
(0.13)\end{array}$ & $\begin{array}{c}0.057 \\
(0.056)\end{array}$ & $\begin{array}{l}-0.051 \\
(0.040)\end{array}$ & $\begin{array}{l}-0.029 \\
(0.033)\end{array}$ & $\begin{array}{l}-0.021 \\
(0.063)\end{array}$ \\
\hline$\Delta \ln \left(\text { income }^{\text {mean }}\right)_{t}$ & $\begin{array}{l}-0.13^{*} \\
(0.076)\end{array}$ & $\begin{array}{l}-0.090^{\star *} \\
(0.038)\end{array}$ & $\begin{array}{l}-0.00032 \\
(0.027)\end{array}$ & $\begin{array}{c}0.044 \\
(0.028)\end{array}$ & $\begin{array}{c}0.020 \\
(0.036)\end{array}$ \\
\hline$\Delta \ln \left(\text { income }^{\text {mean }}\right)_{\mathrm{t}-1}$ & $\begin{array}{l}-0.12 \\
(0.11)\end{array}$ & $\begin{array}{l}-0.17^{* \star *} \\
(0.055)\end{array}$ & $\begin{array}{l}-0.025 \\
(0.045)\end{array}$ & $\begin{array}{l}-0.045 \\
(0.032)\end{array}$ & $\begin{array}{r}0.12^{* \star} \\
(0.057)\end{array}$ \\
\hline $\begin{array}{l}\text { Underlying } \\
\text { primary spending }\end{array}$ & $\begin{array}{l}0.066 \\
(0.10)\end{array}$ & $\begin{array}{l}0.0066 \\
(0.055)\end{array}$ & $\begin{array}{l}-0.10^{* *} \\
(0.049)\end{array}$ & $\begin{array}{l}-0.049 \\
(0.040)\end{array}$ & $\begin{array}{c}0.052 \\
(0.064)\end{array}$ \\
\hline $\begin{array}{l}\text { Marginal tax wedge } \\
\text { (67\% mean income) }\end{array}$ & $\begin{array}{l}0.0015 \\
(0.16)\end{array}$ & $\begin{array}{l}0.12 \\
(0.077)\end{array}$ & $\begin{array}{l}0.076 \\
(0.054)\end{array}$ & $\begin{array}{l}0.00030 \\
(0.038)\end{array}$ & $\begin{array}{l}-0.088 \\
(0.083)\end{array}$ \\
\hline $\begin{array}{l}\text { Marginal tax wedge } \\
\text { (167\% mean income) }\end{array}$ & $\begin{array}{l}0.27^{* *} \\
(0.11)\end{array}$ & $\begin{array}{c}0.074 \\
(0.055)\end{array}$ & $\begin{array}{l}-0.028 \\
(0.041)\end{array}$ & $\begin{array}{l}-0.036 \\
(0.035)\end{array}$ & $\begin{array}{l}-0.055 \\
(0.063)\end{array}$ \\
\hline $\begin{array}{l}\text { Observations } \\
\mathrm{R}^{2}\end{array}$ & $\begin{array}{c}285 \\
0.701\end{array}$ & $\begin{array}{l}285 \\
0.878\end{array}$ & $\begin{array}{l}285 \\
0.940\end{array}$ & $\begin{array}{l}285 \\
0.965\end{array}$ & $\begin{array}{c}285 \\
0.894\end{array}$ \\
\hline
\end{tabular}

Note: The adjusted $\mathrm{R}$ squared does not incorporate the effect of country and year fixed effects. Asterisks $\left({ }^{*},{ }^{* *},{ }^{* * *}\right)$ indicate the significance level $(10 \%, 5 \%, 1 \%)$ of the coefficients. Standard errors are robust to arbitrary heteroskedasticity and autocorrelation (HAC). See Appendix Table A3.1 for data coverage. 
39. The effect of personal income taxation on disposable income is further investigated with a specific set of regressions with the PIT top marginal rate. For this purpose, an indicator measuring the extent to which the PIT top marginal rate is used, taking into account not only the top marginal rate, but also the threshold at which it kicks in, is calculated (Box 2). This top marginal rate strongly reduces disposable income of the top quintile (Table 4). It is also associated with disposable income gains for most other quintiles. The result is robust to the use of pre-crisis data only (Table A1.3), or to the use of tax revenue instead of government spending to control for the size of government (Table A1.4). The overall share of PIT in total revenues does not lead to such a sharp result, as the redistributive effect of PIT depends not only on its size but also its progressivity. The top marginal rate shows no significant effect either, suggesting that reducing the threshold at which this top marginal rate kicks in is more effective than increasing the rate to reduce inequality. The reduction of the threshold affects those most that are close to this threshold. Compared with the highest earners, these tax payers may be less mobile or rely less on tax optimisation to avoid the top marginal rate.

Table 4. The effect of the top PIT rate on the income distribution

\begin{tabular}{|c|c|c|c|c|c|}
\hline Dependent variable & $\ln \left(\right.$ income $\left.^{q^{1}}\right)$ & $\ln \left(\right.$ income $\left.^{q^{2}}\right)$ & $\ln \left(\right.$ income $\left.{ }^{q 3}\right)$ & $\ln \left(\right.$ income $\left.^{q^{4}}\right)$ & $\ln \left(\right.$ income $\left.e^{q 5}\right)$ \\
\hline $\ln \left(\text { income }^{\text {mean }}\right)_{t}$ & $\begin{array}{l}1.13^{* * *} \\
(0.079)\end{array}$ & $\begin{array}{l}1.09^{* * *} \\
(0.037)\end{array}$ & $\begin{array}{l}1.03^{* * *} \\
(0.026)\end{array}$ & $\begin{array}{l}1.01^{\star * \star} \\
(0.018)\end{array}$ & $\begin{array}{l}0.93^{* * *} \\
(0.038)\end{array}$ \\
\hline$\Delta \ln \left(\text { income }^{\text {mean }}\right)_{t+1}$ & $\begin{array}{l}0.12 \\
(0.14)\end{array}$ & $\begin{array}{l}-0.014 \\
(0.068)\end{array}$ & $\begin{array}{l}-0.12^{\star \star \star} \\
(0.042)\end{array}$ & $\begin{array}{l}-0.059^{* *} \\
(0.025)\end{array}$ & $\begin{array}{l}0.081 \\
(0.071)\end{array}$ \\
\hline$\Delta \ln \left(\text { income }^{\text {mean }}\right)_{\mathrm{t}}$ & $\begin{array}{l}-0.030 \\
(0.14)\end{array}$ & $\begin{array}{l}-0.17^{\star *} \\
(0.070)\end{array}$ & $\begin{array}{l}-0.12^{\star \star *} \\
(0.046)\end{array}$ & $\begin{array}{l}-0.049 \\
(0.035)\end{array}$ & $\begin{array}{l}0.13^{*} \\
(0.070)\end{array}$ \\
\hline$\Delta \ln \left(\text { income }^{\text {mean }}\right)_{t-1}$ & $\begin{array}{c}0.13 \\
(0.13)\end{array}$ & $\begin{array}{l}-0.27^{* * *} \\
(0.073)\end{array}$ & $\begin{array}{l}-0.20^{* \star *} \\
(0.058)\end{array}$ & $\begin{array}{l}-0.13^{* * *} \\
(0.038)\end{array}$ & $\begin{array}{l}0.23^{* * *} \\
(0.071)\end{array}$ \\
\hline $\begin{array}{l}\text { Underlying } \\
\text { primary spending }\end{array}$ & $\begin{array}{l}0.42^{* * *} \\
(0.14)\end{array}$ & $\begin{array}{l}0.15^{* *} \\
(0.058)\end{array}$ & $\begin{array}{l}-0.084^{* *} \\
(0.041)\end{array}$ & $\begin{array}{l}-0.087^{* *} \\
(0.039)\end{array}$ & $\begin{array}{l}-0.077 \\
(0.064)\end{array}$ \\
\hline TMR use & $\begin{array}{l}7.15^{\star \star *} \\
(2.10)\end{array}$ & $\begin{array}{l}3.37^{* \star *} \\
(0.83)\end{array}$ & $\begin{array}{l}2.09^{* * *} \\
(0.51)\end{array}$ & $\begin{array}{l}1.21^{* * *} \\
(0.40)\end{array}$ & $\begin{array}{l}-4.56^{* * *} \\
(0.86)\end{array}$ \\
\hline $\begin{array}{l}\text { Observations } \\
\mathrm{R}^{2}\end{array}$ & $\begin{array}{l}297 \\
0.731\end{array}$ & $\begin{array}{l}297 \\
0.897\end{array}$ & $\begin{array}{l}297 \\
0.943\end{array}$ & $\begin{array}{r}297 \\
0.968\end{array}$ & $\begin{array}{r}297 \\
0.886\end{array}$ \\
\hline
\end{tabular}

Note: The adjusted $\mathrm{R}$ squared does not incorporate the effect of country and year fixed effects. Asterisks $\left({ }^{*},{ }^{* *},{ }^{* * *}\right)$ indicate the significance level $(10 \%, 5 \%, 1 \%)$ of the coefficients. Standard errors are robust to arbitrary heteroskedasticity and autocorrelation (HAC). See Appendix Table A3.1 for data coverage.

\section{Box 2. Approximating the relevance of the top marginal PIT rate}

The present study builds a simple indicator to approximate the relevance of the top marginal rate of personal income tax. The underlying idea is that the same top marginal rate has different implications depending on whether many or few people face it. The indicator, called use of the top the marginal rate, is obtained by multiplying the top marginal rate and an estimate of the income share of persons who earn more than the threshold at which it kicks in. The lower the threshold is, the more numerous the people who pay this top rate will be. This share is endogenous, as labour supply decisions can be affected by taxation: one can choose a job with a lower pay and more leisure in the case of a high top marginal rate. In this paper, a virtual share is calculated, assuming a similar distribution of top income in all countries. This is a proxy for the intrinsic theoretical share that would prevail in the absence of taxation. The advantage of this calculation is that this virtual share of persons in the top bracket only depends on the threshold, avoiding the endogeneity issue that would arise when using observed shares.

The virtual income distribution that would prevail without taxation is assumed to follow in all countries a Pareto law with a Pareto coefficient $\alpha$ equal to 2 (in line with the magnitudes found in Ruiz and Woloszko, 2016). The income share of those that are typically affected by the top marginal tax rate is thus:

Share $=\frac{\alpha}{\alpha-1} \frac{x_{0}{ }^{\alpha}}{\left(\frac{T M R \text { threshold }}{\text { GDP percapita }}\right)^{\alpha-1}}$ where $\mathrm{x}_{0}$ is a scaling parameter that is arbitrarily set to 0.1 here and does not influence simulation results, as it only changes the scale of the variable (Figure 3). 
Box 2. Approximating the relevance of the top marginal PIT rate (cont.)

Figure 3. Stylised share of the population that is facing the top marginal tax rate

population

density

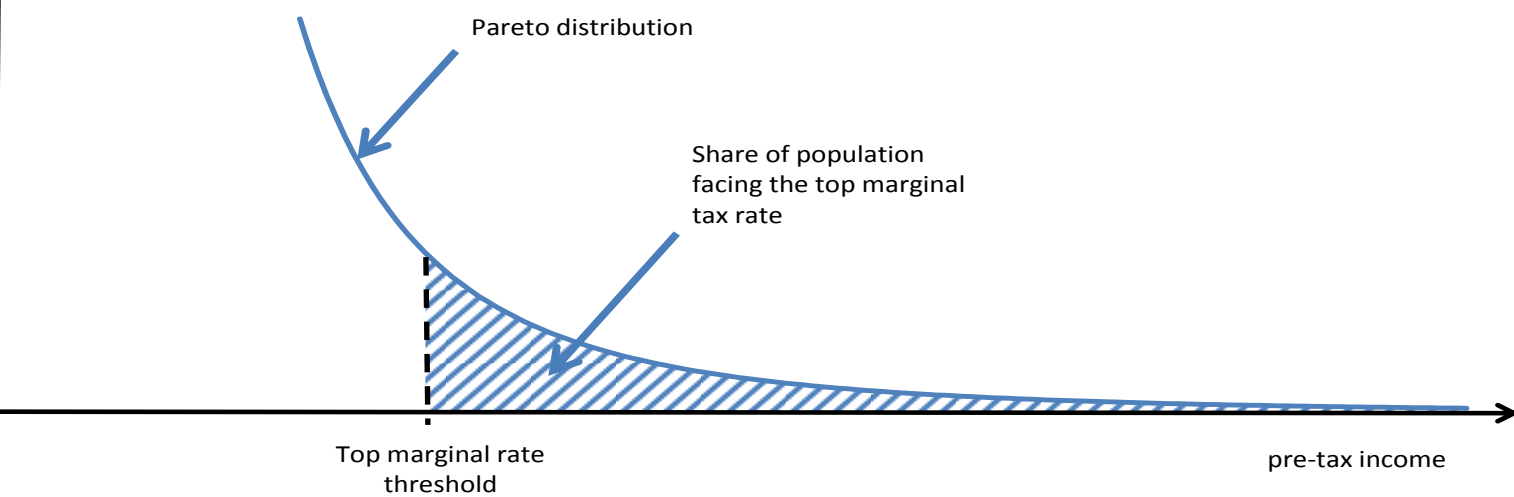

In the presence of a tax allowance, the top marginal tax rate threshold is adjusted to reflect the threshold applied to income before the tax allowance deduction.

\subsection{A focus on the inequality effects of environmental taxation}

40. There are indications that environmental taxes can increase inequality: increasing them as part of a revenue shift keeping government size constant can reduce middle income earnings, while it can favour the top quintile (Table 5). This finding could reflect an effect on lower-middle income self-employed whose operating profit is reduced by environmental taxation. This result could also reflect a broader downward pressure on wages in more polluting sectors, such as transport, in which the share of middle relative to top income earners can be higher. Other OECD research (OECD, 2006; Oueslati et al., 2016) and the results in Table 5 indicate that reforms that increase environmental taxes and are part of packages involving reductions in low-income labour tax wedges can alleviate rather than exacerbate disposable income inequality.

41. The estimates do not take into account the different structure of consumption across quintiles for lack of suitable consumption-distribution data. Micro-simulation studies suggest that the consumption share of products subject to environmental taxes varies across the income distribution (OECD, 2014a). Flues and Thomas (2015) provide country-specific data by expenditure decile for transport fuel taxes.

42. There are therefore signs that increases in environmental taxes, when not part of packages involving reductions in the tax burden of low-income households, may have negative effects for inequality. However, underprivileged households may benefit more than others from less pollution, as they tend to be more exposed to pollution than higher income households, especially in urban areas (Finkelstein et al., 2003; Pinault et al., 2017; Serret and Johnstone, 2006). 
Table 5. The effect of environmental taxes on the income distribution

\begin{tabular}{|c|c|c|c|c|c|}
\hline Dependent variable & $\ln \left(\right.$ income $\left.^{q 1}\right)$ & In(income $\left.{ }^{q 2}\right)$ & $\ln \left(\right.$ income $\left.^{q^{3}}\right)$ & $\ln \left(\right.$ income $\left.^{q 4}\right)$ & $\ln \left(\right.$ income $\left.^{q^{5}}\right)$ \\
\hline $\ln \left(\text { income }^{\text {mean }}\right)_{t}$ & $\begin{array}{l}1.17^{\star \star \star} \\
(0.098)\end{array}$ & $\begin{array}{l}1.00^{* \star *} \\
(0.045)\end{array}$ & $\begin{array}{l}0.94^{* * *} \\
(0.030)\end{array}$ & $\begin{array}{l}0.96^{\star \star \star} \\
(0.018)\end{array}$ & $\begin{array}{l}1.02^{\star \star \star} \\
(0.049)\end{array}$ \\
\hline$\Delta \ln \left(\text { income }^{\text {mean }}\right)_{t+1}$ & $\begin{array}{l}0.17 \\
(0.13)\end{array}$ & $\begin{array}{l}0.0078 \\
(0.054)\end{array}$ & $\begin{array}{l}-0.054 \\
(0.040)\end{array}$ & $\begin{array}{l}-0.010 \\
(0.030)\end{array}$ & $\begin{array}{l}-0.0065 \\
(0.066)\end{array}$ \\
\hline$\Delta \ln \left(\text { income }^{\text {mean }}\right)_{t}$ & $\begin{array}{l}-0.057 \\
(0.092)\end{array}$ & $\begin{array}{l}-0.048 \\
(0.047)\end{array}$ & $\begin{array}{r}0.0091 \\
(0.031)\end{array}$ & $\begin{array}{c}0.032 \\
(0.028)\end{array}$ & $\begin{array}{l}0.00032 \\
(0.050)\end{array}$ \\
\hline$\Delta \ln \left(\text { income }^{\text {mean }}\right)_{t-1}$ & $\begin{array}{l}0.031 \\
(0.12)\end{array}$ & $\begin{array}{l}-0.15^{\star \star *} \\
(0.057)\end{array}$ & $\begin{array}{l}-0.094^{* *} \\
(0.040)\end{array}$ & $\begin{array}{l}-0.097^{* * *} \\
(0.026)\end{array}$ & $\begin{array}{l}0.16^{\star \star} \\
(0.068)\end{array}$ \\
\hline $\begin{array}{l}\text { Underlying } \\
\text { primary spending }\end{array}$ & $\begin{array}{c}0.15 \\
(0.10)\end{array}$ & $\begin{array}{c}0.033 \\
(0.053)\end{array}$ & $\begin{array}{l}-0.098^{* *} \\
(0.049)\end{array}$ & $\begin{array}{l}-0.054 \\
(0.040)\end{array}$ & $\begin{array}{c}0.041 \\
(0.066)\end{array}$ \\
\hline $\begin{array}{l}\text { Average tax wedge } \\
\text { (67\% mean income) }\end{array}$ & $\begin{array}{l}-0.43^{*} \\
(0.26)\end{array}$ & $\begin{array}{l}-0.23^{*} \\
(0.13)\end{array}$ & $\begin{array}{l}-0.029 \\
(0.082)\end{array}$ & $\begin{array}{l}0.056 \\
(0.061)\end{array}$ & $\begin{array}{l}0.14 \\
(0.14)\end{array}$ \\
\hline $\begin{array}{l}\text { Average tax wedge } \\
\text { (167\% mean income) }\end{array}$ & $\begin{array}{l}0.59^{* * *} \\
(0.17)\end{array}$ & $\begin{array}{l}0.37^{* * *} \\
(0.10)\end{array}$ & $\begin{array}{l}0.0023 \\
(0.100)\end{array}$ & $\begin{array}{l}-0.14^{*} \\
(0.072)\end{array}$ & $\begin{array}{l}-0.19 \\
(0.13)\end{array}$ \\
\hline $\begin{array}{l}\text { Environmental taxes } \\
\text { as a share of GDP }\end{array}$ & $\begin{array}{l}-1.52 \\
(1.88)\end{array}$ & $\begin{array}{l}-1.82^{* *} \\
(0.91)\end{array}$ & $\begin{array}{l}-1.76^{\star \star} \\
(0.73)\end{array}$ & $\begin{array}{l}-1.35^{\star \star \star} \\
(0.42)\end{array}$ & $\begin{array}{l}2.40^{* *} \\
(1.12)\end{array}$ \\
\hline $\begin{array}{l}\text { Observations } \\
R^{2}\end{array}$ & $\begin{array}{c}270 \\
0.731\end{array}$ & $\begin{array}{r}270 \\
0.891\end{array}$ & $\begin{array}{r}270 \\
0.942 \\
\end{array}$ & $\begin{array}{r}270 \\
0.970\end{array}$ & $\begin{array}{c}270 \\
0.894\end{array}$ \\
\hline
\end{tabular}

Note: The adjusted $\mathrm{R}$ squared does not incorporate the effect of country and year fixed effects. Asterisks $\left({ }^{*},{ }^{* *},{ }^{* \star \star}\right)$ indicate the significance level $(10 \%, 5 \%, 1 \%)$ of the coefficients. Standard errors are robust to arbitrary heteroskedasticity and autocorrelation (HAC). See Appendix Table A3.1 for data coverage.

\subsection{A focus on the inequality effects of property taxes}

43. Property taxes have contrasted inequality effects depending on their nature. Recurrent taxes on immovable property have no significant effect on the distribution of disposable income (Table 6). By contrast, recurrent taxes on net wealth have a significant inequality reducing effect. Among the nonrecurrent property taxes, inheritance taxes (including gift taxes and estate taxes) also have a significant inequality reducing effect. These two results reflect a mechanical income transfer effect as these taxes target wealthy people who tend also to be high-income people. The other property tax instruments have no significant effect on the income distribution, potentially because these are small instruments that have a negligible effect on the distribution of income.

Table 6. The effect of property taxes on the income distribution

\begin{tabular}{|c|c|c|c|c|c|}
\hline Dependent variable & $\ln \left(\right.$ income $\left.^{q^{1}}\right)$ & $\ln \left(\right.$ income $\left.^{q 2}\right)$ & $\ln \left(\right.$ income $\left.\mathrm{q}^{\mathrm{3}}\right)$ & $\ln \left(\right.$ income $\left.^{q 4}\right)$ & $\ln \left(\right.$ income $\left.{ }^{q 5}\right)$ \\
\hline $\begin{array}{l}\text { Recurrent taxes } \\
\text { on immovable property }\end{array}$ & $\begin{array}{l}-1.93 \\
(2.51)\end{array}$ & $\begin{array}{l}-0.080 \\
(1.43)\end{array}$ & $\begin{array}{l}-0.36 \\
(1.07)\end{array}$ & $\begin{array}{l}-0.011 \\
(0.78)\end{array}$ & $\begin{array}{c}0.23 \\
(1.60)\end{array}$ \\
\hline $\begin{array}{l}\text { Recurrent taxes } \\
\text { on net wealth }\end{array}$ & $\begin{array}{c}4.29 \\
(4.68)\end{array}$ & $\begin{array}{l}4.19^{* *} \\
(2.06)\end{array}$ & $\begin{array}{l}3.03^{* *} \\
(1.37)\end{array}$ & $\begin{array}{c}1.13 \\
(1.09)\end{array}$ & $\begin{array}{l}-4.74^{* *} \\
(2.24)\end{array}$ \\
\hline Inheritance taxes & $\begin{array}{l}17.3^{\star *} \\
(6.86)\end{array}$ & $\begin{array}{l}8.35^{\star \star} \\
(3.72)\end{array}$ & $\begin{array}{c}4.28 \\
(2.76)\end{array}$ & $\begin{array}{c}3.94 \\
(2.41)\end{array}$ & $\begin{array}{c}-12.0^{\star \star *} \\
(4.06)\end{array}$ \\
\hline $\begin{array}{l}\text { Taxes on financial and } \\
\text { capital transactions }\end{array}$ & $\begin{array}{l}-0.75 \\
(2.67)\end{array}$ & $\begin{array}{l}-1.21 \\
(1.42)\end{array}$ & $\begin{array}{l}-0.53 \\
(1.04)\end{array}$ & $\begin{array}{l}-0.22 \\
(0.66)\end{array}$ & $\begin{array}{c}1.42 \\
(1.49)\end{array}$ \\
\hline $\begin{array}{l}\text { Non-recurrent taxes } \\
\text { on property }\end{array}$ & $\begin{array}{l}-0.49 \\
(2.32)\end{array}$ & $\begin{array}{l}-1.61 \\
(1.09)\end{array}$ & $\begin{array}{l}-1.19 \\
(0.80)\end{array}$ & $\begin{array}{l}-0.76 \\
(0.60)\end{array}$ & $\begin{array}{c}1.70 \\
(1.18)\end{array}$ \\
\hline
\end{tabular}

Note: Revenues as shares of GDP of property taxes are cyclically-adjusted and are included one by one on top of the model used in Table 3. Inheritance taxes include gift taxes and estate taxes. A control for total property taxes in included. The results are similar without this additional control. Asterisks $\left({ }^{*},{ }^{* *},{ }^{* *}\right)$ indicate the significance level $(10 \%, 5 \%, 1 \%)$ of the coefficients. Standard errors are robust to arbitrary heteroskedasticity and autocorrelation (HAC). See Appendix Table A3.1 for data coverage. 


\section{Estimation results: Output}

44. For an unchanged size of government, existing evidence from previous OECD (Arnold et al., 2011) and other work surveyed in Section 2 suggests that a shift in the tax mix will durably boost output when it moves the tax burden away from corporate or personal income towards land or consumption taxes. Estimation results conducted according to the framework described in Section 3 and reported throughout this section are broadly in line with this expectation. They add to the existing OECD and other literature by bringing more detailed indications about output effects of tax mix changes and additional robustness through the use of data covering more countries, a longer time span and a new empirical strategy.

\subsection{Effects of tax shifts involving changes in CIT, PIT or VAT rates all considered together}

45. A first set of estimations groups indicators of three major taxes: corporate income taxes, personal income tax and value added tax. These estimates control for the size of government spending or revenue, implying that shifts towards or away from any of the taxes covered by these indicators involve a corresponding adjustment in other taxes (or possibly also the deficit when controlling for government spending). The indicators for CIT and VAT are the effective marginal rate and standard rate respectively, as discussed in Section 3. The top marginal rate is used for PIT, because the literature indicates that it can have a substantial influence on long-term output and also because the indicator covers many countries and years, so that the three indicators are jointly available for a sufficient number of countries and years to estimate.

46. The estimation results indicate that tax shifts involving cuts in effective marginal rates of corporate income tax are typically associated with permanent increases in output levels (Table 7). The results are robust to controlling for government revenue rather than spending. This finding is in line with the literature indicating that higher marginal tax rates on corporate income reduce incentives to supply more capital or increase its productivity. Comparing results controlling or not for physical and human capital investment (i.e. Column 1 vs Column 2 and Column 3 vs. Column 4) suggests that the productivity channel matters more than the capital accumulation channel. 
Table 7. Output effects of the tax structure

\begin{tabular}{|c|c|c|c|c|}
\hline & (1) & (2) & (3) & (4) \\
\hline $\begin{array}{l}\text { Explanatory variables } \\
\text { (all lagged): }\end{array}$ & \multicolumn{4}{|c|}{ Dependent variable: Potential output growth per capita } \\
\hline \multicolumn{5}{|l|}{ Production function } \\
\hline $\begin{array}{l}\text { Ln potential output } \\
\text { per capita }\end{array}$ & $\begin{array}{l}-0.066^{* \star *} \\
(0.014)\end{array}$ & $\begin{array}{c}-0.070^{* * *} \\
(0.013)\end{array}$ & $\begin{array}{c}-0.064^{* * *} \\
(0.015)\end{array}$ & $\begin{array}{c}-0.069^{* * *} \\
(0.014)\end{array}$ \\
\hline Ln physical investment & $\begin{array}{l}0.018^{\star \star *} \\
(0.0066)\end{array}$ & & $\begin{array}{l}0.020^{\star * *} \\
(0.0065)\end{array}$ & \\
\hline Ln human capital investment & $\begin{array}{c}0.12^{*} \\
(0.064)\end{array}$ & & $\begin{array}{l}0.14^{* *} \\
(0.067)\end{array}$ & \\
\hline Working-age population growth & $\begin{array}{l}-0.35 \\
(0.25) \\
\end{array}$ & $\begin{array}{l}-0.12 \\
(0.20) \\
\end{array}$ & $\begin{array}{l}-0.21 \\
(0.24)\end{array}$ & $\begin{array}{l}0.080 \\
(0.19) \\
\end{array}$ \\
\hline \multicolumn{5}{|l|}{ Additional variables } \\
\hline Market potential & $\begin{array}{l}0.012^{\star * \star} \\
(0.0039)\end{array}$ & $\begin{array}{l}0.012^{\star \star *} \\
(0.0040)\end{array}$ & $\begin{array}{l}0.016^{\star \star *} \\
(0.0042)\end{array}$ & $\begin{array}{l}0.016^{\star * *} \\
(0.0044)\end{array}$ \\
\hline Inflation & $\begin{array}{l}-0.029 \\
(0.020)\end{array}$ & $\begin{array}{l}-0.030^{*} \\
(0.018)\end{array}$ & $\begin{array}{l}-0.030 \\
(0.020)\end{array}$ & $\begin{array}{l}-0.033^{*} \\
(0.019)\end{array}$ \\
\hline Private credit to GDP & $\begin{array}{l}-0.0033 \\
(0.0021)\end{array}$ & $\begin{array}{l}-0.0032 \\
(0.0028)\end{array}$ & $\begin{array}{l}-0.0048^{* *} \\
(0.0020)\end{array}$ & $\begin{array}{l}-0.0052^{*} \\
(0.0027)\end{array}$ \\
\hline Old age dependency ratio & $\begin{array}{l}-0.0038 \\
(0.036) \\
\end{array}$ & $\begin{array}{l}-0.023 \\
(0.035) \\
\end{array}$ & $\begin{array}{l}-0.030 \\
(0.042) \\
\end{array}$ & $\begin{array}{l}-0.056 \\
(0.041) \\
\end{array}$ \\
\hline Government variables & & & & \\
\hline Governance quality & $\begin{array}{l}0.0050^{* * *} \\
(0.0018)\end{array}$ & $\begin{array}{c}0.0069^{* * *} \\
(0.0019)\end{array}$ & $\begin{array}{l}0.0054^{* * *} \\
(0.0019)\end{array}$ & $\begin{array}{l}0.0076^{* * *} \\
(0.0020)\end{array}$ \\
\hline $\begin{array}{l}\text { Government primary } \\
\text { spending }\end{array}$ & $\begin{array}{c}-0.056^{\star \star \star} \\
(0.014)\end{array}$ & $\begin{array}{c}-0.062^{* * *} \\
(0.014)\end{array}$ & & \\
\hline Total revenue to GDP ratio & & & $\begin{array}{l}0.0090 \\
(0.023)\end{array}$ & $\begin{array}{l}0.0096 \\
(0.025)\end{array}$ \\
\hline VAT standard rate & $\begin{array}{l}-0.028 \\
(0.042)\end{array}$ & $\begin{array}{l}-0.036 \\
(0.045)\end{array}$ & $\begin{array}{l}0.0066 \\
(0.041)\end{array}$ & $\begin{array}{l}0.00033 \\
(0.044)\end{array}$ \\
\hline $\begin{array}{l}\text { Effective marginal } \\
\text { CIT tax rate }\end{array}$ & $\begin{array}{l}-0.024^{*} \\
(0.014)\end{array}$ & $\begin{array}{l}-0.028^{\star *} \\
(0.014)\end{array}$ & $\begin{array}{l}-0.027^{*} \\
(0.016)\end{array}$ & $\begin{array}{l}-0.033^{\star *} \\
(0.016)\end{array}$ \\
\hline Top marginal PIT rate & $\begin{array}{c}-0.012 \\
(0.0085) \\
\end{array}$ & $\begin{array}{c}-0.014 \\
(0.0085) \\
\end{array}$ & $\begin{array}{l}-0.014^{*} \\
(0.0083)\end{array}$ & $\begin{array}{l}-0.016^{*} \\
(0.0084)\end{array}$ \\
\hline Observations & 491 & 491 & 491 & 491 \\
\hline Adjusted R-squared & 0.361 & 0.323 & 0.316 & 0.264 \\
\hline
\end{tabular}

Note: All regressions include country and time fixed effects. Asterisks $\left({ }^{*},{ }^{* *},{ }^{* \star *}\right)$ indicate the significance level $(10 \%, 5 \%, 1 \%)$ of the coefficients. Standard errors are robust to arbitrary heteroskedasticity and autocorrelation (HAC). See Appendix Table A3.1 for data coverage.

\subsection{A focus on corporate income tax}

47. The estimation of the output effects of the corporate income tax uses marginal effective tax rates (METR). In contrast to statutory rates, METRs aim to measure the effective impact of CIT on a marginal investment by taking into account tax provisions, such as depreciation rules and deductions. Marginal effective tax rates better explain observed tax payments than statutory rates (Akgun et al., 2017; Schimanski, 2017). 
48. The empirical analysis uncovers a strongly significant, statistically stable, negative link from marginal effective rates of CIT on long-term growth (Table 8). The result holds when controlling for the top marginal rate of PIT (which has a negative but not robustly significant association with output, Column 2). This result is consistent with the economic literature and earlier OECD research (Arnold et al., 2011), which it extends by the focus on effective marginal rates and the additional findings on the basebroadening effect and differences in CIT rates with trade partners (see below). The main channel seems related to the effect of CIT on incentives to improve returns on capital, such as through innovation, rather than to accumulate a bigger volume of capital, since dropping the physical investment control does not materially strengthen the results (Column 5). There are also indications that greater use of dividend imputation weakens the negative output effect of CIT effective rates (Column 6).

49. The empirical analysis also suggests positive long-term output effects of broadening the base of the corporate income tax. Estimating output effects of the effective marginal rate together with a proxy for the base and compliance, in the form of the amount of money raised by CIT as a ratio to GDP, shows that the impact of the rate remains negative while the impact of the proxy for the base is positive (Column 3). These findings are obtained even though METRs capture part (but not all) of the base definition effect, suggesting that the underlying effect is strong. These results corroborate and support the analysis and recommendations by the OECD (2010) in favour of a low rate-broad base approach.

50. Governments often motivate CIT rate cuts by the aim of attracting investment and thereby boosting output (OECD, 2016c, 2017b). A body of evidence indicates that CIT differentials influence foreign direct investment though by small amounts compared with other policies (Hajkova et al., 2007). These considerations raise a question about the output effects of cross-country CIT rate differentials. To address it, this study has compiled an indicator which compares the effective marginal rate of CIT in one country to a distance-weighted average of the CIT METRs in other countries. This CIT METR differential turns out to have a negative effect on long-term output (Column 4). This effect is similar in statistical significance and economic size to the one of the domestic CIT METR without considering CIT METRs in other countries (Column 3). This observation and other econometric investigations (available on request) indicate that the effect of the CIT METR differential is not statistically distinguishable from that of the domestic CIT effective rate considered alone. 
ECO/WKP(2017)79

Table 8. Output effects of the corporate income tax

\begin{tabular}{|c|c|c|c|c|c|c|}
\hline & $(1)$ & (2) & (3) & $(4)$ & $(5)$ & (6) \\
\hline Explanatory variables (all lagged): & \multicolumn{6}{|c|}{ Dependent variable: Potential output growth per capita } \\
\hline \multicolumn{7}{|l|}{ Production function } \\
\hline Ln potential output per capita & $\begin{array}{c}-0.063^{\star * *} \\
(0.013)\end{array}$ & $\begin{array}{c}-0.066^{* * *} \\
(0.014)\end{array}$ & $\begin{array}{c}-0.069^{* * *} \\
(0.014)\end{array}$ & $\begin{array}{c}-0.058^{* * *} \\
(0.015)\end{array}$ & $\begin{array}{c}-0.071^{* * *} \\
(0.013)\end{array}$ & $\begin{array}{c}-0.061^{* * *} \\
(0.013)\end{array}$ \\
\hline Ln physical investment & $\begin{array}{l}0.016^{* *} \\
(0.0068)\end{array}$ & $\begin{array}{l}0.018^{\star * *} \\
(0.0066)\end{array}$ & $\begin{array}{l}0.017^{\star \star \star} \\
(0.0064)\end{array}$ & $\begin{array}{l}0.019^{* * *} \\
(0.0066)\end{array}$ & & $\begin{array}{l}0.024^{\star * *} \\
(0.0068)\end{array}$ \\
\hline Ln human capital investment & $\begin{array}{c}0.12^{*} \\
(0.065)\end{array}$ & $\begin{array}{c}0.12^{*} \\
(0.064)\end{array}$ & $\begin{array}{l}0.14^{* *} \\
(0.061)\end{array}$ & $\begin{array}{l}0.15^{\star *} \\
(0.067)\end{array}$ & $\begin{array}{c}0.078 \\
(0.061)\end{array}$ & $\begin{array}{l}0.18^{* * *} \\
(0.060)\end{array}$ \\
\hline Working-age population growth & $\begin{array}{l}-0.35 \\
(0.24)\end{array}$ & $\begin{array}{l}-0.35 \\
(0.25)\end{array}$ & $\begin{array}{l}-0.39 \\
(0.24)\end{array}$ & $\begin{array}{l}-0.45^{\star} \\
(0.24)\end{array}$ & $\begin{array}{l}-0.13 \\
(0.20)\end{array}$ & $\begin{array}{l}-0.055 \\
(0.22)\end{array}$ \\
\hline \multicolumn{7}{|l|}{ Additional variables } \\
\hline Market potential & $\begin{array}{l}0.011^{\star * *} \\
(0.0034)\end{array}$ & $\begin{array}{l}0.012^{* * *} \\
(0.0039)\end{array}$ & $\begin{array}{l}0.011^{* * *} \\
(0.0037)\end{array}$ & $\begin{array}{l}0.0089^{* *} \\
(0.0037)\end{array}$ & $\begin{array}{l}0.013^{* * *} \\
(0.0038)\end{array}$ & $\begin{array}{l}0.018^{* * *} \\
(0.0026)\end{array}$ \\
\hline Inflation & $\begin{array}{l}-0.029 \\
(0.020)\end{array}$ & $\begin{array}{l}-0.029 \\
(0.020)\end{array}$ & $\begin{array}{l}-0.028 \\
(0.019)\end{array}$ & $\begin{array}{c}0.013 \\
(0.021)\end{array}$ & $\begin{array}{l}-0.031^{*} \\
(0.018)\end{array}$ & $\begin{array}{l}-0.04{ }^{*} \\
(0.021)\end{array}$ \\
\hline Private credit to GDP & $\begin{array}{l}-0.0020 \\
(0.0022)\end{array}$ & $\begin{array}{l}-0.0033 \\
(0.0021)\end{array}$ & $\begin{array}{l}-0.0031 \\
(0.0020)\end{array}$ & $\begin{array}{l}-0.0021 \\
(0.0022)\end{array}$ & $\begin{array}{l}-0.0030 \\
(0.0028)\end{array}$ & $\begin{array}{l}-0.0022 \\
(0.0018)\end{array}$ \\
\hline Old age dependency ratio & $\begin{array}{l}-0.026 \\
(0.032) \\
\end{array}$ & $\begin{array}{c}-0.0038 \\
(0.036)\end{array}$ & $\begin{array}{c}-0.0028 \\
(0.034) \\
\end{array}$ & $\begin{array}{c}0.016 \\
(0.035) \\
\end{array}$ & $\begin{array}{l}-0.027 \\
(0.035) \\
\end{array}$ & $\begin{array}{c}-0.052^{\star *} \\
(0.025)\end{array}$ \\
\hline \multicolumn{7}{|l|}{ Government variables } \\
\hline Governance quality & $\begin{array}{c}0.0055^{\star * *} \\
(0.0019)\end{array}$ & $\begin{array}{c}0.0050^{* * *} \\
(0.0018)\end{array}$ & $\begin{array}{c}0.0047^{* * *} \\
(0.0017)\end{array}$ & $\begin{array}{l}0.0041^{* *} \\
(0.0016)\end{array}$ & $\begin{array}{c}0.0069^{* * *} \\
(0.0019)\end{array}$ & $\begin{array}{c}0.0067^{* * *} \\
(0.0018)\end{array}$ \\
\hline Government primary spending ratio to GDP & $\begin{array}{c}-0.049^{\star * \star} \\
(0.013)\end{array}$ & $\begin{array}{c}-0.056^{\star \star \star} \\
(0.014)\end{array}$ & $\begin{array}{c}-0.048^{\star * \star} \\
(0.014)\end{array}$ & $\begin{array}{c}-0.051^{\star \star \star} \\
(0.015)\end{array}$ & $\begin{array}{c}-0.061^{\star * \star} \\
(0.014)\end{array}$ & $\begin{array}{c}-0.035^{\star * *} \\
(0.011)\end{array}$ \\
\hline Marginal effective CIT tax rate & $\begin{array}{c}-0.030^{* *} \\
(0.013)\end{array}$ & $\begin{array}{l}-0.024^{*} \\
(0.014)\end{array}$ & $\begin{array}{c}-0.032^{* *} \\
(0.014)\end{array}$ & & $\begin{array}{l}-0.027^{*} \\
(0.014)\end{array}$ & $\begin{array}{c}-0.044^{* * *} \\
(0.017)\end{array}$ \\
\hline Top marginal PIT rate & & $\begin{array}{c}-0.012 \\
(0.0085)\end{array}$ & $\begin{array}{l}-0.019^{\star *} \\
(0.0096)\end{array}$ & $\begin{array}{c}-0.028^{\star \star \star} \\
(0.010)\end{array}$ & $\begin{array}{l}-0.016^{\star} \\
(0.0084)\end{array}$ & \\
\hline VAT standard rate & & $\begin{array}{l}-0.028 \\
(0.042)\end{array}$ & $\begin{array}{l}-0.038 \\
(0.043)\end{array}$ & $\begin{array}{l}-0.038 \\
(0.046)\end{array}$ & $\begin{array}{l}-0.031 \\
(0.044)\end{array}$ & \\
\hline Ratio of CIT receipts to GDP & & & $\begin{array}{l}0.13^{\star \star *} \\
(0.049)\end{array}$ & $\begin{array}{l}0.16^{\star \star *} \\
(0.055)\end{array}$ & & \\
\hline $\begin{array}{l}\text { Difference of domestic METR of CIT and } \\
\text { METR of CIT in other countries }\end{array}$ & & & & $\begin{array}{l}-0.026^{*} \\
(0.015)\end{array}$ & & \\
\hline $\begin{array}{l}\text { CIT rate interacted with the PIT } \\
\text { dividend imputation rate }\end{array}$ & & & & & & $\begin{array}{l}0.0018^{* *} \\
(0.00085)\end{array}$ \\
\hline Observations & 528 & 491 & 491 & 436 & 491 & 446 \\
\hline Adjusted R-squared & 0.347 & 0.361 & 0.377 & 0.370 & 0.329 & 0.472 \\
\hline
\end{tabular}

Note: All regressions include country and year fixed effects. The dependent variable is the change in the logarithm of potential GDP per capita. Asterisks $\left({ }^{*},{ }^{* *},{ }^{* * *}\right)$ indicate the significance level $(10 \%, 5 \%, 1 \%)$ of the coefficients. Standard errors are robust to arbitrary heteroskedasticity and autocorrelation (HAC). The adjusted R squared does not incorporate the effect of country and year fixed effects. See Appendix Table A3.1 for data coverage. 


\subsection{A focus on personal income tax wedges}

51. The empirical analysis confirms theoretical views and the earlier empirical literature about the adverse effects of personal income taxes on economic growth. The analysis is conducted using marginal effective tax wedges from the OECD Taxing Wages database, which take into account the taxation of personal income in a broad sense: they include narrowly defined PIT plus social security contributions and the marginal effects of benefit withdrawal.

52. Higher labour tax wedges on individuals below or above average incomes are associated with lower long-term output, in contrast with mean-income workers (Table 9). Below average income earners are more likely to suffer from weaker attachment to the labour market than people earning mean incomes. Also by comparison with workers on mean incomes, above average income earners may get lower marginal utility from additional income, which can imply that they are more likely to supply less labour when it becomes more taxed. The potential explanations for these three groups are in line with economic theory and other evidence that elasticities of labour income to tax rates are high at the top and bottom of the income distribution but not at its average.

53. Two consequences of these results are that, for unchanged tax wedges on average income and a fixed government size (implying compensating adjustments in other revenue sources or the deficit):

- Greater progressivity in the bottom half of the distribution that stems from a reduction in the labour tax wedge on low incomes is linked with higher long-term output levels.

- Greater progressivity in the top half of the distribution that results from an increase in the labour tax wedge on above average incomes entails lower long-term output levels.

54. The various effects at different income levels sum to a negative overall impact of higher rates of the personal income tax, defined broadly, on long-term GDP. The average tax wedge at $167 \%$ of mean income summarises all marginal tax wedges at lower income levels; in technical terms, the average tax wedge at that level is the integral of all the marginal tax wedges that apply below this level. The long-term effect on output of this average tax wedge is significantly negative (Columns 3 and 6). 
Table 9. Output effects of the tax wedge

\begin{tabular}{|c|c|c|c|c|c|c|}
\hline & (1) & (2) & (3) & (4) & (5) & (6) \\
\hline \multicolumn{7}{|l|}{ Production function } \\
\hline Ln potential output per capita & $\begin{array}{c}-0.057^{* * *} \\
(0.011)\end{array}$ & $\begin{array}{c}-0.055^{\star * *} \\
(0.011)\end{array}$ & $\begin{array}{c}-0.058^{* * *} \\
(0.011)\end{array}$ & $\begin{array}{c}-0.048^{* * *} \\
(0.014)\end{array}$ & $\begin{array}{c}-0.046^{* * *} \\
(0.014)\end{array}$ & $\begin{array}{l}-0.052^{* * *} \\
(0.014)\end{array}$ \\
\hline Ln physical investment & $\begin{array}{l}0.015^{\star \star} \\
(0.0061)\end{array}$ & $\begin{array}{l}0.016^{\star * *} \\
(0.0060)\end{array}$ & $\begin{array}{l}0.016^{\star * \star} \\
(0.0062)\end{array}$ & $\begin{array}{l}0.024^{\star * *} \\
(0.0061)\end{array}$ & $\begin{array}{l}0.025^{\star * *} \\
(0.0059)\end{array}$ & $\begin{array}{l}0.025^{\star * \star} \\
(0.0062)\end{array}$ \\
\hline Ln human capital investment & $\begin{array}{c}0.13^{*} \\
(0.070)\end{array}$ & $\begin{array}{c}0.12^{*} \\
(0.069)\end{array}$ & $\begin{array}{c}0.14^{*} \\
(0.073)\end{array}$ & $\begin{array}{l}0.16^{\star \star} \\
(0.065)\end{array}$ & $\begin{array}{l}0.16^{\star *} \\
(0.063)\end{array}$ & $\begin{array}{l}0.16^{\star *} \\
(0.070)\end{array}$ \\
\hline $\begin{array}{l}\text { Working-age } \\
\text { population growth }\end{array}$ & $\begin{array}{l}-0.39^{* *} \\
(0.20) \\
\end{array}$ & $\begin{array}{l}-0.36^{*} \\
(0.20)\end{array}$ & $\begin{array}{l}-0.39^{\star} \\
(0.21)\end{array}$ & $\begin{array}{l}-0.55^{\star * *} \\
(0.20)\end{array}$ & $\begin{array}{l}-0.52^{* *} \\
(0.21)\end{array}$ & $\begin{array}{l}-0.57^{\star *} \\
(0.23) \\
\end{array}$ \\
\hline \multicolumn{7}{|l|}{ Additional variables } \\
\hline Market potential & $\begin{array}{l}0.010^{* * *} \\
(0.0032)\end{array}$ & $\begin{array}{l}0.0096^{\star * \star} \\
(0.0032)\end{array}$ & $\begin{array}{l}0.0098^{* * *} \\
(0.0033)\end{array}$ & $\begin{array}{l}0.0081^{* *} \\
(0.0035)\end{array}$ & $\begin{array}{l}0.0081^{* *} \\
(0.0035)\end{array}$ & $\begin{array}{l}0.0075^{\star *} \\
(0.0036)\end{array}$ \\
\hline Inflation & $\begin{array}{l}-0.012 \\
(0.016)\end{array}$ & $\begin{array}{l}-0.017 \\
(0.015)\end{array}$ & $\begin{array}{l}-0.0056 \\
(0.017)\end{array}$ & $\begin{array}{c}0.023 \\
(0.017)\end{array}$ & $\begin{array}{c}0.018 \\
(0.017)\end{array}$ & $\begin{array}{c}0.028 \\
(0.018)\end{array}$ \\
\hline Private credit to GDP & $\begin{array}{l}-0.0041 \\
(0.0030)\end{array}$ & $\begin{array}{l}-0.0040 \\
(0.0030)\end{array}$ & $\begin{array}{l}-0.0040 \\
(0.0029)\end{array}$ & $\begin{array}{l}-0.0030 \\
(0.0026)\end{array}$ & $\begin{array}{l}-0.0030 \\
(0.0025)\end{array}$ & $\begin{array}{l}-0.0028 \\
(0.0024)\end{array}$ \\
\hline Old age dependency ratio & $\begin{array}{l}-0.025 \\
(0.034) \\
\end{array}$ & $\begin{array}{l}-0.018 \\
(0.034) \\
\end{array}$ & $\begin{array}{l}-0.023 \\
(0.036) \\
\end{array}$ & $\begin{array}{c}0.026 \\
(0.033) \\
\end{array}$ & $\begin{array}{c}0.031 \\
(0.033) \\
\end{array}$ & $\begin{array}{c}0.026 \\
(0.036) \\
\end{array}$ \\
\hline \multicolumn{7}{|l|}{ Government variables } \\
\hline Governance quality & $\begin{array}{l}0.0058^{* * *} \\
(0.0015)\end{array}$ & $\begin{array}{l}0.0054^{* * *} \\
(0.0015)\end{array}$ & $\begin{array}{l}0.0063^{* * *} \\
(0.0016)\end{array}$ & $\begin{array}{l}0.0032^{* *} \\
(0.0016)\end{array}$ & $\begin{array}{l}0.0028^{*} \\
(0.0016)\end{array}$ & $\begin{array}{l}0.0038^{* *} \\
(0.0016)\end{array}$ \\
\hline $\begin{array}{l}\text { Government primary } \\
\text { spending }\end{array}$ & $\begin{array}{c}-0.043^{\star * *} \\
(0.012)\end{array}$ & $\begin{array}{l}-0.044^{* * *} \\
(0.012)\end{array}$ & $\begin{array}{l}-0.044^{* * *} \\
(0.013)\end{array}$ & $\begin{array}{l}-0.044^{* * *} \\
(0.013)\end{array}$ & $\begin{array}{l}-0.043^{* * *} \\
(0.013)\end{array}$ & $\begin{array}{l}-0.046^{* * *} \\
(0.015)\end{array}$ \\
\hline $\begin{array}{l}\text { Marginal tax wedge at } 67 \% \\
\text { of mean income }\end{array}$ & $\begin{array}{l}-0.045^{* * *} \\
(0.014)\end{array}$ & $\begin{array}{c}-0.050^{* * *} \\
(0.014)\end{array}$ & & $\begin{array}{c}-0.048^{* * *} \\
(0.014)\end{array}$ & $\begin{array}{l}-0.053^{* * *} \\
(0.015)\end{array}$ & \\
\hline $\begin{array}{l}\text { Marginal tax wedge } \\
\text { at mean income }\end{array}$ & & $\begin{array}{l}0.015^{\star *} \\
(0.0068)\end{array}$ & & & $\begin{array}{l}0.014^{\star *} \\
(0.0072)\end{array}$ & \\
\hline $\begin{array}{l}\text { Marginal tax wedge at } 167 \% \\
\text { of mean income }\end{array}$ & $\begin{array}{l}-0.028^{* *} \\
(0.012)\end{array}$ & $\begin{array}{l}-0.036^{* * *} \\
(0.012)\end{array}$ & & $\begin{array}{l}-0.022^{* *} \\
(0.011)\end{array}$ & $\begin{array}{l}-0.029^{* * *} \\
(0.011)\end{array}$ & \\
\hline $\begin{array}{l}\text { Average tax wedge at } 167 \% \\
\text { of mean income }\end{array}$ & & & $\begin{array}{c}-0.067^{\star * *} \\
(0.017)\end{array}$ & & & $\begin{array}{l}-0.060^{* * *} \\
(0.018)\end{array}$ \\
\hline $\begin{array}{l}\text { Effective marginal tax rate } \\
\text { of CIT }\end{array}$ & & & & $\begin{array}{l}0.0015 \\
(0.014)\end{array}$ & $\begin{array}{l}0.0053 \\
(0.014)\end{array}$ & $\begin{array}{l}-0.0027 \\
(0.015)\end{array}$ \\
\hline VAT standard rate & & & & $\begin{array}{l}-0.029 \\
(0.042) \\
\end{array}$ & $\begin{array}{l}-0.025 \\
(0.041) \\
\end{array}$ & $\begin{array}{l}-0.032 \\
(0.042) \\
\end{array}$ \\
\hline Observations & 481 & 481 & 481 & 431 & 431 & 431 \\
\hline R-squared & 0.387 & 0.395 & 0.358 & 0.405 & 0.414 & 0.369 \\
\hline
\end{tabular}

Note: All regressions include country and year fixed effects. The dependent variable is the change in the logarithm of potential GDP per capita. Note: Asterisks $\left({ }^{*},{ }^{* *},{ }^{* *}\right)$ indicate the significance level $(10 \%, 5 \%, 1 \%)$ of the coefficients. Standard errors are robust to arbitrary heteroskedasticity and autocorrelation (HAC). The adjusted R squared does not incorporate the effect of country and year fixed effects. See Appendix Table A3.1 for data coverage. 


\subsection{A focus on value added tax}

55. There is no significant association between standard VAT rates and long-term GDP (Tables 10 and A2.3). The regressions use the standard rates, which apply to the majority of the VAT base. Investigations have also considered VAT receipts to detect if the data might reveal contrasting effects of rates and the base as for the corporate income tax, but these inquiries did not identify any such effects.

Table 10. Output effects of value added tax

\begin{tabular}{|c|c|c|c|c|}
\hline & (1) & $(2)$ & (3) & (4) \\
\hline Explanatory variables (all lagged): & \multicolumn{4}{|c|}{ Dependent variable: Potential output growth per capita } \\
\hline \multicolumn{5}{|l|}{ Production function } \\
\hline Ln potential output per capita & $\begin{array}{c}-0.061^{* * *} \\
(0.0093)\end{array}$ & $\begin{array}{c}-0.062^{* * *} \\
(0.0094)\end{array}$ & $\begin{array}{c}-0.063^{* * *} \\
(0.013)\end{array}$ & $\begin{array}{c}-0.066^{* * *} \\
(0.014)\end{array}$ \\
\hline Ln physical investment & $\begin{array}{c}0.013^{* *} \\
(0.0062)\end{array}$ & $\begin{array}{l}0.012^{* *} \\
(0.0060)\end{array}$ & $\begin{array}{l}0.016^{\star *} \\
(0.0067)\end{array}$ & $\begin{array}{l}0.017^{* * *} \\
(0.0065)\end{array}$ \\
\hline Ln human capital investment & $\begin{array}{c}0.10 \\
(0.063)\end{array}$ & $\begin{array}{c}0.10 \\
(0.063)\end{array}$ & $\begin{array}{c}0.12^{*} \\
(0.065)\end{array}$ & $\begin{array}{c}0.12^{*} \\
(0.063)\end{array}$ \\
\hline Working-age population growth & $\begin{array}{l}-0.30 \\
(0.21) \\
\end{array}$ & $\begin{array}{l}-0.31 \\
(0.22) \\
\end{array}$ & $\begin{array}{l}-0.39 \\
(0.25) \\
\end{array}$ & $\begin{array}{l}-0.38 \\
(0.25) \\
\end{array}$ \\
\hline \multicolumn{5}{|l|}{ Additional variables } \\
\hline Market potential & $\begin{array}{l}0.011^{\star * \star} \\
(0.0034)\end{array}$ & $\begin{array}{l}0.011^{\star \star \star} \\
(0.0033)\end{array}$ & $\begin{array}{l}0.011^{* * *} \\
(0.0037)\end{array}$ & $\begin{array}{l}0.012^{* \star *} \\
(0.0039)\end{array}$ \\
\hline Inflation & $\begin{array}{c}-0.031^{* *} \\
(0.015)\end{array}$ & $\begin{array}{l}-0.029^{*} \\
(0.016)\end{array}$ & $\begin{array}{l}-0.024 \\
(0.021)\end{array}$ & $\begin{array}{l}-0.025 \\
(0.021)\end{array}$ \\
\hline Private credit to GDP & $\begin{array}{l}-0.0023 \\
(0.0024)\end{array}$ & $\begin{array}{l}-0.0024 \\
(0.0023)\end{array}$ & $\begin{array}{l}-0.0018 \\
(0.0022)\end{array}$ & $\begin{array}{l}-0.0035^{*} \\
(0.0020)\end{array}$ \\
\hline Old age dependency ratio & $\begin{array}{l}-0.020 \\
(0.034)\end{array}$ & $\begin{array}{l}-0.024 \\
(0.033) \\
\end{array}$ & $\begin{array}{l}-0.024 \\
(0.033) \\
\end{array}$ & $\begin{array}{l}-0.010 \\
(0.035)\end{array}$ \\
\hline \multicolumn{5}{|l|}{ Government variables } \\
\hline Governance quality & $\begin{array}{c}0.0064^{* * *} \\
(0.0018)\end{array}$ & $\begin{array}{c}0.0064^{* * *} \\
(0.0018)\end{array}$ & $\begin{array}{c}0.0052^{* \star *} \\
(0.0018)\end{array}$ & $\begin{array}{c}0.0050^{\star * *} \\
(0.0018)\end{array}$ \\
\hline Government primary spending & $\begin{array}{c}-0.041^{\star \star *} \\
(0.014)\end{array}$ & $\begin{array}{c}-0.041^{* \star *} \\
(0.014)\end{array}$ & $\begin{array}{c}-0.052^{\star * *} \\
(0.014)\end{array}$ & $\begin{array}{c}-0.057^{\star * *} \\
(0.014)\end{array}$ \\
\hline VAT standard rate & $\begin{array}{l}-0.059 \\
(0.043)\end{array}$ & $\begin{array}{l}-0.063 \\
(0.044)\end{array}$ & $\begin{array}{l}-0.039 \\
(0.045)\end{array}$ & $\begin{array}{l}-0.039 \\
(0.045)\end{array}$ \\
\hline Ratio of VAT receipts to GDP & & $\begin{array}{c}0.040 \\
(0.077)\end{array}$ & $\begin{array}{c}0.028 \\
(0.076)\end{array}$ & $\begin{array}{c}0.068 \\
(0.084)\end{array}$ \\
\hline CIT effective marginal rate & & & $\begin{array}{l}-0.031^{* *} \\
(0.014)\end{array}$ & $\begin{array}{l}-0.024^{*} \\
(0.014)\end{array}$ \\
\hline PIT top marginal rate & & & & $\begin{array}{c}-0.010 \\
(0.0090)\end{array}$ \\
\hline Observations & 567 & 567 & 508 & 491 \\
\hline R-squared & 0.340 & 0.341 & 0.348 & 0.363 \\
\hline
\end{tabular}

Note: All regressions include country and time fixed effects. The dependent variable is the change in the logarithm of potential GDP per capita. Asterisks $\left({ }^{*},{ }^{* *},{ }^{* * *}\right)$ indicate the significance level $(10 \%, 5 \%, 1 \%)$ of the coefficients. Standard errors are robust to arbitrary heteroskedasticity and autocorrelation (HAC). The adjusted R squared does not incorporate the effect of country and year fixed effects. See Appendix Table A3.1 for data coverage. 


\subsection{The role of environmental and property taxes}

56. Analyses of environmental and property taxes use the ratios of their receipts to GDP for lack of suitable cross-country data for tax rates. By contrast, long, internationally comparable time series are available for tax receipts from the OECD Revenue Statistics. The use of receipts, however, implies that the analysis is made a further step away from policy levers than for the taxes on corporate income, personal income and value added.

57. The results show no effect of environmental taxes on long-term output (Column 1 in Table 11). This finding about long-term output neutrality of environmental taxes in the revenue mix is consistent with and complements OECD evidence that environmental regulation is neutral for productivity growth (Albrizio et al., 2014).

58. Property taxes re-group different items that have contrasting effect (Columns 2-7).

- The first group comprises taxes that are collected on an on-going basis:

- Recurrent taxes on immovable property (i.e. yearly land and building taxes): theory and empirical analysis generally consider such taxes as growth-friendly (see for instance Arnold et al., 2011). Indeed, tax shifts towards higher reliance on recurrent taxes on immovable property in total revenue are positively linked with more long-term output (Column 3 in Table 11).

- Recurrent taxes on net wealth: theory suggests that they reduce savings and therefore output (Tanzi, 1995; Mankiw et al., 2009) although there have been debates around the possibility that avoidance might reduce their output effect (Diamond and Saez, 2011; Seim, 2017). The estimate indeed suggests that tax shifts involving reductions in taxes on net wealth are linked with higher output (Column 4).

- The second group consists of taxes levied on specific events:

- The literature is largely split on inheritance taxes (Boadway et al., 2009). Higher inheritance taxes can reduce the incentive to save among those who want to leave an estate to the next generation but symmetrically increase this incentive among heirs who know they will get less after tax. The estimates suggest that the net output effect of higher inheritance taxes is positive (Column 5).

- Transaction taxes are generally seen as negative for long-term output (Diamond and Mirrlees, 1971). In the regressions, the coefficient has the expected sign, but is not significant (Column 6).

- Pure one-off taxes on wealth are generally seen as growth-compatible, insofar as people do not expect them to be repeated. In line with this view, one-off taxes on property are estimated to be associated with higher long-term levels of output (Column 7). 
ECO/WKP(2017)79

Table 11. Output effects of environmental and property taxes

\begin{tabular}{|c|c|c|c|c|c|c|c|}
\hline & (1) & $(2)$ & (3) & (4) & (5) & (6) & (7) \\
\hline Explanatory variables (all lagged): & \multicolumn{7}{|c|}{ Dependent variable: Potential output growth per capita } \\
\hline \multicolumn{8}{|l|}{ Production function } \\
\hline Ln potential output per capita & $\begin{array}{c}-0.066^{* * *} \\
(0.016)\end{array}$ & $\begin{array}{c}-0.067^{* * *} \\
(0.016)\end{array}$ & $\begin{array}{c}-0.061^{* * *} \\
(0.013)\end{array}$ & $\begin{array}{c}-0.067^{* * *} \\
(0.014)\end{array}$ & $\begin{array}{c}-0.069^{* * *} \\
(0.014)\end{array}$ & $\begin{array}{c}-0.065^{* * *} \\
(0.014)\end{array}$ & $\begin{array}{c}-0.065^{\star * *} \\
(0.014)\end{array}$ \\
\hline Ln physical investment & $\begin{array}{c}0.017^{\star *} \\
(0.0068)\end{array}$ & $\begin{array}{l}0.018^{* * *} \\
(0.0067)\end{array}$ & $\begin{array}{l}0.022^{\star * *} \\
(0.0064)\end{array}$ & $\begin{array}{l}0.016^{* *} \\
(0.0063)\end{array}$ & $\begin{array}{l}0.019^{\star * *} \\
(0.0064)\end{array}$ & $\begin{array}{l}0.019^{\star * *} \\
(0.0064)\end{array}$ & $\begin{array}{l}0.018^{\star * *} \\
(0.0066)\end{array}$ \\
\hline Ln human capital investment & $\begin{array}{c}0.13^{*} \\
(0.067)\end{array}$ & $\begin{array}{c}0.12^{*} \\
(0.066)\end{array}$ & $\begin{array}{l}0.12^{\star *} \\
(0.060)\end{array}$ & $\begin{array}{l}0.14^{* *} \\
(0.064)\end{array}$ & $\begin{array}{l}0.16^{* *} \\
(0.062)\end{array}$ & $\begin{array}{l}0.12^{\star \star} \\
(0.062)\end{array}$ & $\begin{array}{c}0.12^{* *} \\
(0.062)\end{array}$ \\
\hline Working-age population growth & $\begin{array}{l}-0.29 \\
(0.25) \\
\end{array}$ & $\begin{array}{l}-0.28 \\
(0.25) \\
\end{array}$ & $\begin{array}{l}-0.28 \\
(0.24) \\
\end{array}$ & $\begin{array}{l}-0.39^{*} \\
(0.21) \\
\end{array}$ & $\begin{array}{l}-0.36 \\
(0.24) \\
\end{array}$ & $\begin{array}{l}-0.30 \\
(0.24) \\
\end{array}$ & $\begin{array}{l}-0.31 \\
(0.24) \\
\end{array}$ \\
\hline \multicolumn{8}{|l|}{ Additional variables } \\
\hline Market potential & $\begin{array}{l}0.013^{* * *} \\
(0.0036)\end{array}$ & $\begin{array}{l}0.013^{* * *} \\
(0.0037)\end{array}$ & $\begin{array}{l}0.013^{* * *} \\
(0.0034)\end{array}$ & $\begin{array}{l}0.014^{* * *} \\
(0.0034)\end{array}$ & $\begin{array}{l}0.015^{\star * *} \\
(0.0035)\end{array}$ & $\begin{array}{l}0.013^{* * *} \\
(0.0034)\end{array}$ & $\begin{array}{l}0.013^{\star * *} \\
(0.0034)\end{array}$ \\
\hline Inflation & $\begin{array}{l}-0.028 \\
(0.020)\end{array}$ & $\begin{array}{l}-0.028 \\
(0.020)\end{array}$ & $\begin{array}{l}-0.033^{*} \\
(0.018)\end{array}$ & $\begin{array}{l}-0.041^{* *} \\
(0.019)\end{array}$ & $\begin{array}{l}-0.034^{*} \\
(0.020)\end{array}$ & $\begin{array}{l}-0.030 \\
(0.019)\end{array}$ & $\begin{array}{l}-0.032^{*} \\
(0.019)\end{array}$ \\
\hline Private credit to GDP & $\begin{array}{l}-0.0034 \\
(0.0021)\end{array}$ & $\begin{array}{l}-0.0036^{*} \\
(0.0020)\end{array}$ & $\begin{array}{l}-0.0041^{* *} \\
(0.0020)\end{array}$ & $\begin{array}{c}-0.0042^{* *} \\
(0.0018)\end{array}$ & $\begin{array}{l}-0.0031 \\
(0.0020)\end{array}$ & $\begin{array}{l}-0.0036^{*} \\
(0.0021)\end{array}$ & $\begin{array}{l}-0.0036^{*} \\
(0.0021)\end{array}$ \\
\hline Old age dependency ratio & $\begin{array}{l}0.0024 \\
(0.036)\end{array}$ & $\begin{array}{l}0.0012 \\
(0.036)\end{array}$ & $\begin{array}{l}0.0068 \\
(0.034) \\
\end{array}$ & $\begin{array}{l}-0.014 \\
(0.032)\end{array}$ & $\begin{array}{l}-0.013 \\
(0.033) \\
\end{array}$ & $\begin{array}{c}-0.0059 \\
(0.033)\end{array}$ & $\begin{array}{c}-0.0073 \\
(0.034)\end{array}$ \\
\hline \multicolumn{8}{|l|}{ Government variables } \\
\hline Governance Quality & $\begin{array}{c}0.0052^{* * *} \\
(0.0019)\end{array}$ & $\begin{array}{l}0.0049^{* *} \\
(0.0019)\end{array}$ & $\begin{array}{c}0.0047^{* * *} \\
(0.0017)\end{array}$ & $\begin{array}{c}0.0046^{\star * *} \\
(0.0016)\end{array}$ & $\begin{array}{l}0.0041^{* *} \\
(0.0017)\end{array}$ & $\begin{array}{c}0.0049^{* * *} \\
(0.0018)\end{array}$ & $\begin{array}{c}0.0049^{* * *} \\
(0.0017)\end{array}$ \\
\hline Government primary spending & $\begin{array}{c}-0.056^{* * *} \\
(0.013)\end{array}$ & $\begin{array}{c}-0.052^{\star * *} \\
(0.013)\end{array}$ & $\begin{array}{c}-0.061^{* * *} \\
(0.014)\end{array}$ & $\begin{array}{c}-0.057^{\star * *} \\
(0.013)\end{array}$ & $\begin{array}{c}-0.051^{* * *} \\
(0.013)\end{array}$ & $\begin{array}{c}-0.051^{* * *} \\
(0.014)\end{array}$ & $\begin{array}{c}-0.049^{\star * *} \\
(0.013)\end{array}$ \\
\hline PIT top marginal rate & $\begin{array}{l}-0.022^{*} \\
(0.013)\end{array}$ & $\begin{array}{l}-0.019 \\
(0.013)\end{array}$ & $\begin{array}{l}-0.016 \\
(0.013)\end{array}$ & $\begin{array}{l}-0.013 \\
(0.012)\end{array}$ & $\begin{array}{l}-0.020 \\
(0.013)\end{array}$ & $\begin{array}{l}-0.020 \\
(0.014)\end{array}$ & $\begin{array}{l}-0.019 \\
(0.014)\end{array}$ \\
\hline CIT effective marginal rate & $\begin{array}{c}-0.011 \\
(0.0085)\end{array}$ & $\begin{array}{c}-0.012 \\
(0.0087)\end{array}$ & $\begin{array}{c}-0.012 \\
(0.0082)\end{array}$ & $\begin{array}{c}-0.014 \\
(0.0087)\end{array}$ & $\begin{array}{l}-0.015^{\star} \\
(0.0084)\end{array}$ & $\begin{array}{c}-0.014 \\
(0.0084)\end{array}$ & $\begin{array}{l}-0.014^{*} \\
(0.0083)\end{array}$ \\
\hline $\begin{array}{l}\text { Property tax receipts } \\
\text { (ratio to GDP) }\end{array}$ & & $\begin{array}{l}-0.14 \\
(0.12)\end{array}$ & $\begin{array}{c}-0.43^{\star \star *} \\
(0.16)\end{array}$ & $\begin{array}{c}0.15 \\
(0.12)\end{array}$ & $\begin{array}{l}-0.25^{\star} \\
(0.13)\end{array}$ & $\begin{array}{l}-0.061 \\
(0.14)\end{array}$ & $\begin{array}{l}-0.16 \\
(0.12)\end{array}$ \\
\hline $\begin{array}{l}\text { Environmental tax receipts } \\
\text { (ratio to GDP) }\end{array}$ & $\begin{array}{l}0.046 \\
(0.16)\end{array}$ & $\begin{array}{l}0.065 \\
(0.16)\end{array}$ & & & & & \\
\hline $\begin{array}{l}\text { Recurrent taxes } \\
\text { on immovable property }\end{array}$ & & & $\begin{array}{l}0.98^{* * *} \\
(0.30)\end{array}$ & & & & \\
\hline Recurrent taxes on net wealth & & & & $\begin{array}{c}-1.31^{* \star *} \\
(0.44)\end{array}$ & & & \\
\hline Estate, inheritance and gift taxes & & & & & $\begin{array}{l}2.13^{* * *} \\
(0.77)\end{array}$ & & \\
\hline $\begin{array}{l}\text { Taxes on financial } \\
\text { and capital transactions }\end{array}$ & & & & & & $\begin{array}{l}-0.19 \\
(0.30)\end{array}$ & \\
\hline $\begin{array}{l}\text { Other non-recurrent taxes } \\
\text { on property }\end{array}$ & & & & & & & $\begin{array}{l}0.44^{* *} \\
(0.22)\end{array}$ \\
\hline Observations & 472 & 472 & 511 & 511 & 511 & 511 & 511 \\
\hline R-squared & 0.375 & 0.378 & 0.386 & 0.396 & 0.382 & 0.365 & 0.366 \\
\hline
\end{tabular}

Note: All regressions include country and year fixed effect. The dependent variable is the change in the logarithm of potential GDP per capita. Asterisks $\left({ }^{*},{ }^{* *},{ }^{* * *}\right)$ indicate the significance level $(10 \%, 5 \%, 1 \%)$ of the coefficients. Standard errors are robust to arbitrary heteroskedasticity and autocorrelation (HAC). The adjusted R squared does not incorporate the effect of country and year fixed effects. See Appendix Table A3.1 for data coverage. 


\subsection{Convergence and other controls}

59. Converge to the long-term GDP level is well identified. The convergence coefficient is significant in all regressions and highly so in nearly all; its estimate mostly evolves within the 0.400.65 range. This result implies that half of the long-term output effects of tax changes materialise within 10 to 17 years. In the presence of fixed effects, this pace of convergence is likely to be overestimated (Nickell, 1981)

60. The other controls mostly provide the anticipated results, though not always in a statistically significant fashion. Governance quality is a remarkably robust driver of long-term growth. Physical and human capital investment both boost long-term growth and in a stronger, more stable way for physical investment. Greater market potential is linked with higher long-term growth. In line with the literature on the costs of inflation, higher inflation generally reduces output. A higher share of older people also reduces GDP. Surprisingly, the regressions detect no positive output effect of a faster expanding working-age population.

\subsection{Relationship with earlier OECD estimates}

61. The estimation method of the growth effect of taxation provided here differs from the one presented in the previous OECD project on the effect of taxes on growth (Arnold et al., 2011). First, the estimation uses tax rates, whenever available, rather than tax receipts. For simulation purposes, the estimates in Akgun et al. (2017) allow calculating the (marginal effective) tax rate changes that are necessary to increase or reduce receipts from CIT, PIT or VAT for a given share of GDP. Furthermore, the present study covers many more countries and more recent observations. Methodologically, as mentioned above, the present study uses the panel country and year fixed effect least squares estimator, whereas the Tax and Growth study used the Pool Mean Group (PMG), which given the number of available observations available per country runs into stability and other estimation issues, as highlighted especially by Xing (2012).

62. Estimates with the PMG estimator used by Arnold et al. (2011) are presented here with more recent data and broader country coverage (Annex Table A2.5). They show negative growth effects of a greater reliance on income taxes and positive effects of consumption and property taxes, in line with a broad body of the literature (see Johansson, 2016 for a review). These replication/updating findings are broadly consistent with the results of the previous study, with the caveat that the current one finds no general positive effect for VAT: this materialises only when governance quality is high, and there can be a negative effect with poor governance quality.

\section{Illustrative simulations of policy reforms}

63. Growth and inequality results are combined here to gauge their overall effect, as in Fournier and Johansson (2016). GDP convergence regressions provide a long-term effect on the level of GDP. This GDP effect is translated here in a one-for-one change of mean disposable income: Hermansen et al. (2016) indeed find an effect of GDP growth on household disposable income that is above one but not significantly different from one. This assumption is also required for long-term consistency: in the very long run, the growth rates of disposable income cannot be above GDP growth (the disposable income to GDP ratio would otherwise explode), neither can it be below GDP growth (the disposable income to GDP ratio would converge to zero). 
64. Results reported here illustrate the effects of tax shifts that, while keeping the government size constant (by raising other revenue sources or borrowing),

- reduce the average personal income tax wedges at $167 \%$ of average income,

- lower the threshold at which the top marginal rate of the personal income tax kicks in,

- reduce the marginal effective rate of corporate income taxes,

- $\quad$ or increase inheritance taxes.

65. The direction of change is chosen so that the average output effect is positive. In each case, the benchmark is the average of the best half of OECD countries. Given the size of revenues collected with income taxation, a reduction of the tax wedge toward this target is unrealistic in several countries; the simulations therefore consider a reduction equivalent to half of the gap between the target and the tax wedge observed in 2013. The other three simulations consider the long-term effect of full convergence towards the target.

66. The results illustrate that the tax structure and especially the share of taxation of personal income can make a strong contribution in explaining the heterogeneity of GDP levels across OECD countries. Average tax wedge decreases for upper-middle income earners (as part of tax shifts) are associated with large income gains for this category (Figure 4, Panel A). Inequality increases, but the growth effect dominates, so that the poor also have an income increase in absolute terms (Figure 4, Panel A).This simulation illustrates the effect of an across-the-board reduction of the tax wedge, while specific reforms can attenuate the trade-off. For instance, a reduction of the marginal tax wedge at the lower end of the income distribution has a positive growth effect with no visible inequality effect. Policy makers can implement such a change by ironing out threshold effects to alleviate distortive marginal tax rates without having to decrease average tax rates much.

67. Lowering the effective rate of corporate income tax (as part of a tax shift) can deliver substantial income gains for all with few consequences for the distribution of income (Figure 4, Panel B). Broadening the base (defined as raising more revenue for a fixed effective rate) also enhances growth without significantly affecting the distribution of income (simulations available on request).

68. Tax shifts involving increases in inheritance taxation can raise average incomes and enhance equality (Figure 4, Panel C). A rise of taxation on immovable property benefits all as the growth effect dominates the insignificant distribution effect). Tax shifts that involve cuts in the taxation of net wealth can raise average income and increase inequality. For the poor, the output effect dominates, so that they benefit in absolute terms from such reforms (simulation available on request). 
Figure 4. Illustrative long-term disposable income effects of tax changes

A. Decrease of the average tax wedge at $167 \%$ of personal income average effect, in per cent

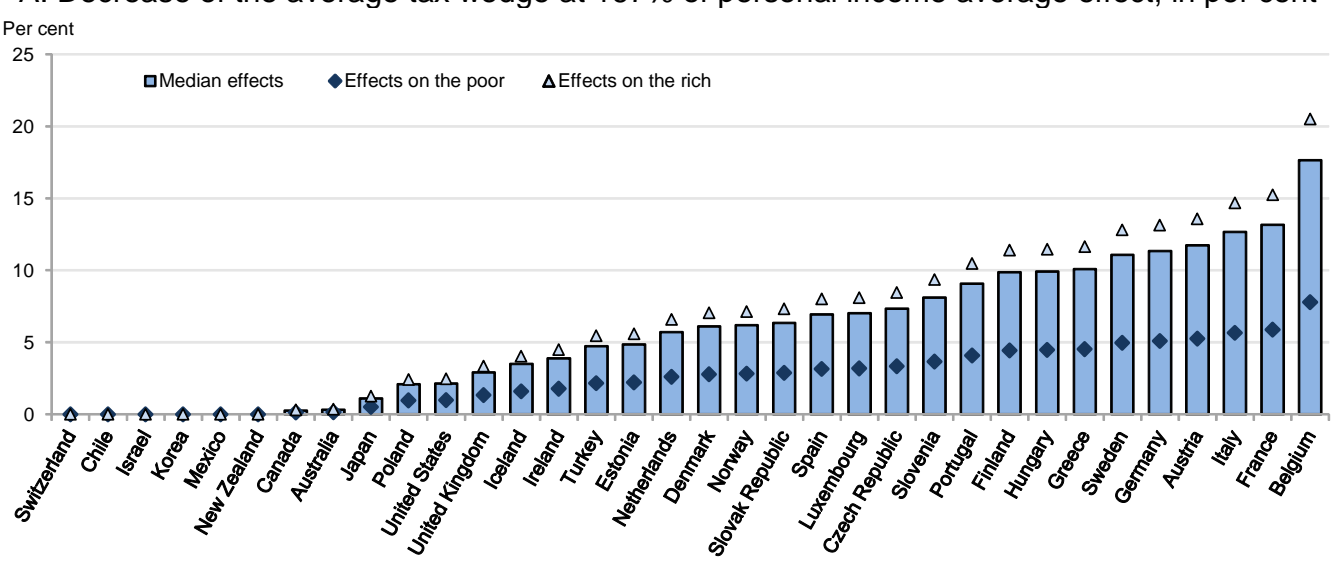

B. Corporate income tax marginal effective rate decrease effect, in per cent

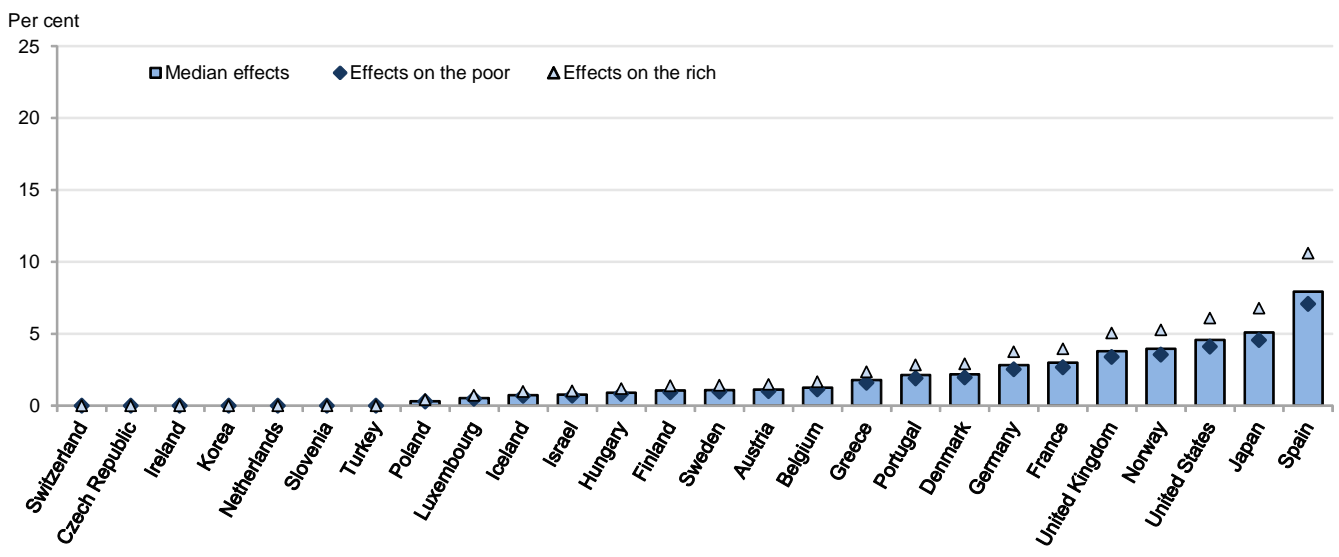

C. Inheritance tax increase effect, in per cent

Per cent

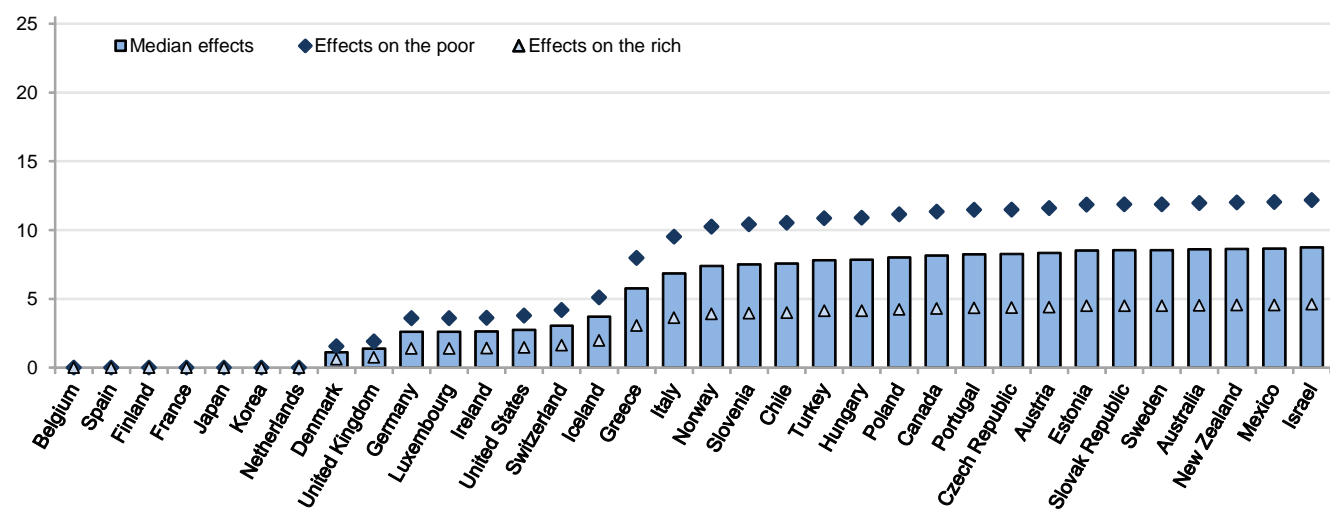

Note: These simulations are illustrative and should be treated as such, as they assume that the average effect estimated across OECD countries will apply in each. Each country may however have specific features that make it depart from the average effect. The median effect is the effect on the third quintile, the effect on the poor is the effect on the first quintile, and the effect on the rich is the effect on the fifth quintile. The target for tax cuts (hikes) is the average of the bottom (top) half of OECD countries in 2013. Given the size of revenues collected with income taxation, a reduction of the tax wedge toward this target is unrealistically large in several countries: consequently, a reduction of only half of the gap between the tax wedge observed in 2013 and the target is assumed. The other two simulations assume full convergence to the target. Inheritance taxes include gift taxes and estate taxes. See Appendix Table A3.1 for coverage of the underlying data.

Source: Authors' calculations based on the results reported in Tables 2, 6, 8 (column 5), 9 (column 3) and 11 (column 5). 
ECO/WKP(2017)79

\section{APPENDIX 1. ADDITIONAL RESULTS ON INEQUALITY}

Table A1.1. The effect of the tax structure on the income distribution

\begin{tabular}{|c|c|c|c|c|c|}
\hline Dependent variable & $\ln \left(\right.$ income $\left.^{q 1}\right)$ & $\ln \left(\right.$ income $\left.^{q^{2}}\right)$ & In(income $\left.{ }^{q 3}\right)$ & $\ln \left(\right.$ income $\left.^{q 4}\right)$ & $\ln \left(\right.$ income $\left.\mathrm{q}^{\mathrm{5}}\right)$ \\
\hline $\ln \left(\text { income }^{\text {mean }}\right)_{t}$ & $\begin{array}{l}1.20^{\star \star \star} \\
(0.11)\end{array}$ & $\begin{array}{l}1.05^{\star * *} \\
(0.054)\end{array}$ & $\begin{array}{l}0.97^{\star \star \star} \\
(0.036)\end{array}$ & $\begin{array}{l}0.97^{\star \star *} \\
(0.024)\end{array}$ & $\begin{array}{l}0.98^{* * *} \\
(0.058)\end{array}$ \\
\hline$\Delta \ln \left(\text { income }^{\text {mean }}\right)_{t+1}$ & $\begin{array}{c}0.14 \\
(0.13)\end{array}$ & $\begin{array}{r}0.016 \\
(0.057)\end{array}$ & $\begin{array}{l}-0.045 \\
(0.045)\end{array}$ & $\begin{array}{l}-0.0049 \\
(0.036)\end{array}$ & $\begin{array}{l}-0.0085 \\
(0.075)\end{array}$ \\
\hline$\Delta \ln \left(\text { income }^{\text {mean }}\right)_{t}$ & $\begin{array}{l}-0.10 \\
(0.091)\end{array}$ & $\begin{array}{l}-0.11^{* *} \\
(0.047)\end{array}$ & $\begin{array}{l}-0.022 \\
(0.035)\end{array}$ & $\begin{array}{r}0.025 \\
(0.031)\end{array}$ & $\begin{array}{r}0.043 \\
(0.051)\end{array}$ \\
\hline$\Delta \ln \left(\text { income }^{\text {mean }}\right)_{t-1}$ & $\begin{array}{l}-0.040 \\
(0.12)\end{array}$ & $\begin{array}{l}-0.16^{\star *} \\
(0.075)\end{array}$ & $\begin{array}{l}-0.081 \\
(0.053)\end{array}$ & $\begin{array}{l}-0.076^{* *} \\
(0.032)\end{array}$ & $\begin{array}{l}0.16^{\star} \\
(0.084)\end{array}$ \\
\hline $\begin{array}{l}\text { Underlying } \\
\text { primary spending }\end{array}$ & $\begin{array}{r}0.064 \\
(0.11)\end{array}$ & $\begin{array}{l}-0.010 \\
(0.057)\end{array}$ & $\begin{array}{l}-0.12^{\star *} \\
(0.051)\end{array}$ & $\begin{array}{l}-0.059 \\
(0.042)\end{array}$ & $\begin{array}{r}0.075 \\
(0.071)\end{array}$ \\
\hline VAT standard rate & $\begin{array}{l}-0.40 \\
(0.34)\end{array}$ & $\begin{array}{l}-0.046 \\
(0.19)\end{array}$ & $\begin{array}{l}0.013 \\
(0.15)\end{array}$ & $\begin{array}{l}0.071 \\
(0.11)\end{array}$ & $\begin{array}{r}0.077 \\
(0.22)\end{array}$ \\
\hline $\begin{array}{l}\text { Effective marginal } \\
\text { CIT rate }\end{array}$ & $\begin{array}{r}0.10 \\
(0.10)\end{array}$ & $\begin{array}{c}0.11^{*} \\
(0.062)\end{array}$ & $\begin{array}{r}0.047 \\
(0.049)\end{array}$ & $\begin{array}{l}-0.0077 \\
(0.032)\end{array}$ & $\begin{array}{l}-0.068 \\
(0.065)\end{array}$ \\
\hline $\begin{array}{l}\text { Average tax wedge } \\
(67 \% \text { mean income })\end{array}$ & $\begin{array}{l}-0.42 \\
(0.27)\end{array}$ & $\begin{array}{l}-0.22^{*} \\
(0.14)\end{array}$ & $\begin{array}{l}-0.0016 \\
(0.086)\end{array}$ & $\begin{array}{r}0.062 \\
(0.068)\end{array}$ & $\begin{array}{l}0.090 \\
(0.15)\end{array}$ \\
\hline $\begin{array}{l}\text { Average tax wedge } \\
\text { (167\% mean income) }\end{array}$ & $\begin{array}{l}0.64^{* * *} \\
(0.15)\end{array}$ & $\begin{array}{l}0.41^{* * *} \\
(0.11)\end{array}$ & $\begin{array}{r}0.015 \\
(0.10) \\
\end{array}$ & $\begin{array}{l}-0.14^{*} \\
(0.078) \\
\end{array}$ & $\begin{array}{l}-0.22^{*} \\
(0.13) \\
\end{array}$ \\
\hline $\begin{array}{l}\text { Observations } \\
\mathrm{R}^{2}\end{array}$ & $\begin{array}{l}256 \\
0.727\end{array}$ & $\begin{array}{l}256 \\
0.887\end{array}$ & $\begin{array}{l}256 \\
0.939\end{array}$ & $\begin{array}{l}256 \\
0.967\end{array}$ & $\begin{array}{l}256 \\
0.888\end{array}$ \\
\hline
\end{tabular}

Note: The adjusted $\mathrm{R}$ squared does not incorporate the effect of country and year fixed effects. Asterisks $\left({ }^{*},{ }^{* *},{ }^{* \star \star}\right)$ indicate the significance level $(10 \%, 5 \%, 1 \%)$ of the coefficients. Standard errors are robust to arbitrary heteroskedasticity and autocorrelation (HAC). See Appendix Table A3.1 for data coverage.

Table A1.2. The effect of the VAT statutory rate and tax wedge on income distribution

\begin{tabular}{|c|c|c|c|c|c|}
\hline Dependent variable & Income $\mathrm{q1}^{1}$ & Income $\mathrm{q}^{2}$ & Income $\mathrm{q}^{3}$ & Income ${ }^{q 4}$ & Income $\mathrm{q}^{\mathrm{g}}$ \\
\hline $\ln \left(\text { income }^{\text {mean }}\right)_{t}$ & $\begin{array}{l}1.17^{* \star \star} \\
(0.11)\end{array}$ & $\begin{array}{l}1.01^{* \star *} \\
(0.050)\end{array}$ & $\begin{array}{l}0.94^{* \star *} \\
(0.032)\end{array}$ & $\begin{array}{l}0.96^{\star \star \star} \\
(0.022)\end{array}$ & $\begin{array}{l}1.02^{* * *} \\
(0.055)\end{array}$ \\
\hline$\Delta \ln \left(\text { income }^{\text {mean }}\right)_{t+1}$ & $\begin{array}{l}0.23^{*} \\
(0.13)\end{array}$ & $\begin{array}{r}0.057 \\
(0.057)\end{array}$ & $\begin{array}{l}-0.048 \\
(0.039)\end{array}$ & $\begin{array}{l}-0.027 \\
(0.034)\end{array}$ & $\begin{array}{l}-0.020 \\
(0.062)\end{array}$ \\
\hline$\Delta \ln \left(\text { income }^{\text {mean }}\right)_{t}$ & $\begin{array}{l}-0.099 \\
(0.075)\end{array}$ & $\begin{array}{l}-0.086^{* *} \\
(0.039)\end{array}$ & $\begin{array}{c}0.0019 \\
(0.027)\end{array}$ & $\begin{array}{r}0.048 \\
(0.029)\end{array}$ & $\begin{array}{r}0.0076 \\
(0.040)\end{array}$ \\
\hline$\Delta \ln \left(\text { income }^{\text {mean }}\right)_{\mathrm{t}-1}$ & $\begin{array}{l}-0.11 \\
(0.11)\end{array}$ & $\begin{array}{l}-0.16^{\star \star \star} \\
(0.056)\end{array}$ & $\begin{array}{l}-0.026 \\
(0.046)\end{array}$ & $\begin{array}{l}-0.047 \\
(0.032)\end{array}$ & $\begin{array}{r}0.12^{* *} \\
(0.059)\end{array}$ \\
\hline $\begin{array}{l}\text { Underlying } \\
\text { primary spending }\end{array}$ & $\begin{array}{l}0.038 \\
(0.11)\end{array}$ & $\begin{array}{l}-0.011 \\
(0.059)\end{array}$ & $\begin{array}{l}-0.11^{* *} \\
(0.049)\end{array}$ & $\begin{array}{l}-0.049 \\
(0.039)\end{array}$ & $\begin{array}{r}0.068 \\
(0.069)\end{array}$ \\
\hline VAT statutory rate & $\begin{array}{l}-0.18 \\
(0.34)\end{array}$ & $\begin{array}{l}-0.012 \\
(0.18)\end{array}$ & $\begin{array}{l}-0.042 \\
(0.14)\end{array}$ & $\begin{array}{l}-0.014 \\
(0.11)\end{array}$ & $\begin{array}{c}0.12 \\
(0.21)\end{array}$ \\
\hline $\begin{array}{l}\text { Average tax wedge } \\
\text { ( } 67 \% \text { mean income) }\end{array}$ & $\begin{array}{l}-0.45^{*} \\
(0.24)\end{array}$ & $\begin{array}{l}-0.22^{*} \\
(0.12)\end{array}$ & $\begin{array}{l}-0.010 \\
(0.082)\end{array}$ & $\begin{array}{r}0.050 \\
(0.067)\end{array}$ & $\begin{array}{c}0.12 \\
(0.14)\end{array}$ \\
\hline $\begin{array}{l}\text { Average tax wedge } \\
(167 \% \text { mean income) }\end{array}$ & $\begin{array}{l}0.58^{* * *} \\
(0.16)\end{array}$ & $\begin{array}{l}0.36^{* * *} \\
(0.10)\end{array}$ & $\begin{array}{l}-0.016 \\
(0.098)\end{array}$ & $\begin{array}{l}-0.15^{\star \star} \\
(0.076)\end{array}$ & $\begin{array}{l}-0.16 \\
(0.12)\end{array}$ \\
\hline $\begin{array}{l}\text { Observations } \\
\mathrm{R}^{2}\end{array}$ & $\begin{array}{l}277 \\
0.703\end{array}$ & $\begin{array}{l}277 \\
0.881\end{array}$ & $\begin{array}{l}277 \\
0.941\end{array}$ & $\begin{array}{l}277 \\
0.966\end{array}$ & $\begin{array}{l}277 \\
0.894\end{array}$ \\
\hline
\end{tabular}

Note: The adjusted $\mathrm{R}$ squared does not incorporate the effect of country and year fixed effects. Asterisks $\left(^{*},{ }^{* *},{ }^{* * *}\right)$ indicate the significance level $(10 \%, 5 \%, 1 \%)$ of the coefficients. Standard errors are robust to arbitrary heteroskedasticity and autocorrelation (HAC). See Appendix Table A3.1 for data coverage. 
Table A1.3 The effect of the effective marginal CIT rate and tax wedge on income distribution

\begin{tabular}{|c|c|c|c|c|c|}
\hline Dependent variable & Income $\mathrm{q}^{\mathrm{q}}$ & Income $\mathrm{q}^{2}$ & Income $\mathrm{q}^{\mathrm{3}}$ & Income $\mathrm{q}^{4}$ & Income $\mathrm{q5}^{\mathrm{5}}$ \\
\hline $\ln \left(\text { income }^{\text {mean }}\right)_{t}$ & $\begin{array}{l}1.23^{\star \star *} \\
(0.095)\end{array}$ & $\begin{array}{l}1.05^{\star \star \star} \\
(0.047)\end{array}$ & $\begin{array}{l}0.96^{\star \star \star} \\
(0.033)\end{array}$ & $\begin{array}{l}0.97^{* \star *} \\
(0.022)\end{array}$ & $\begin{array}{l}0.97^{\star \star *} \\
(0.050)\end{array}$ \\
\hline$\Delta \ln \left(\text { income }^{\text {mean }}\right)_{t+1}$ & $\begin{array}{c}0.15 \\
(0.13)\end{array}$ & $\begin{array}{r}0.015 \\
(0.057)\end{array}$ & $\begin{array}{l}-0.047 \\
(0.045)\end{array}$ & $\begin{array}{l}-0.0056 \\
(0.035)\end{array}$ & $\begin{array}{l}-0.0094 \\
(0.075)\end{array}$ \\
\hline$\Delta \ln \left(\text { income }^{\text {mean }}\right)_{t}$ & $\begin{array}{c}-0.13 \\
(0.091)\end{array}$ & $\begin{array}{l}-0.11^{* *} \\
(0.047)\end{array}$ & $\begin{array}{l}-0.021 \\
(0.033)\end{array}$ & $\begin{array}{r}0.029 \\
(0.029)\end{array}$ & $\begin{array}{r}0.048 \\
(0.049)\end{array}$ \\
\hline$\Delta \ln \left(\text { income }^{\text {mean }}\right)_{t-1}$ & $\begin{array}{l}-0.025 \\
(0.12)\end{array}$ & $\begin{array}{l}-0.16^{\star \star} \\
(0.075)\end{array}$ & $\begin{array}{l}-0.084 \\
(0.052)\end{array}$ & $\begin{array}{c}-0.079^{* * *} \\
(0.030)\end{array}$ & $\begin{array}{l}0.16^{*} \\
(0.083)\end{array}$ \\
\hline $\begin{array}{l}\text { Underlying } \\
\text { primary spending }\end{array}$ & $\begin{array}{r}0.077 \\
(0.11)\end{array}$ & $\begin{array}{l}-0.0092 \\
(0.057)\end{array}$ & $\begin{array}{l}-0.12^{\star *} \\
(0.052)\end{array}$ & $\begin{array}{l}-0.060 \\
(0.042)\end{array}$ & $\begin{array}{r}0.071 \\
(0.070)\end{array}$ \\
\hline $\begin{array}{l}\text { Effective marginal } \\
\text { CIT rate }\end{array}$ & $\begin{array}{r}0.079 \\
(0.11)\end{array}$ & $\begin{array}{c}0.10 \\
(0.064)\end{array}$ & $\begin{array}{r}0.045 \\
(0.050)\end{array}$ & $\begin{array}{l}-0.0040 \\
(0.033)\end{array}$ & $\begin{array}{l}-0.062 \\
(0.067)\end{array}$ \\
\hline $\begin{array}{l}\text { Average tax wedge } \\
(67 \% \text { mean income) }\end{array}$ & $\begin{array}{l}-0.44 \\
(0.27)\end{array}$ & $\begin{array}{l}-0.23^{*} \\
(0.14)\end{array}$ & $\begin{array}{l}-0.0033 \\
(0.086)\end{array}$ & $\begin{array}{r}0.062 \\
(0.067)\end{array}$ & $\begin{array}{l}0.096 \\
(0.15)\end{array}$ \\
\hline $\begin{array}{l}\text { Average tax wedge } \\
\text { (167\% mean income) }\end{array}$ & $\begin{array}{l}0.71^{* * *} \\
(0.16)\end{array}$ & $\begin{array}{l}0.41^{* \star *} \\
(0.10)\end{array}$ & $\begin{array}{r}0.0093 \\
(0.096)\end{array}$ & $\begin{array}{l}-0.15^{\star \star} \\
(0.073)\end{array}$ & $\begin{array}{l}-0.23^{*} \\
(0.12)\end{array}$ \\
\hline $\begin{array}{l}\text { Observations } \\
\mathrm{R}^{2}\end{array}$ & $\begin{array}{l}264 \\
0.725\end{array}$ & $\begin{array}{l}264 \\
0.886\end{array}$ & $\begin{array}{l}264 \\
0.937\end{array}$ & $\begin{array}{l}264 \\
0.966\end{array}$ & $\begin{array}{l}264 \\
0.888\end{array}$ \\
\hline
\end{tabular}

Note: The adjusted $\mathrm{R}$ squared does not incorporate the effect of country and year fixed effects. Asterisks $\left({ }^{*},{ }^{* *},{ }^{* \star *}\right)$ indicate the significance level $(10 \%, 5 \%, 1 \%)$ of the coefficients. Standard errors are robust to arbitrary heteroskedasticity and autocorrelation (HAC). See Appendix Table A3.1 for data coverage.

Table A1.4. The effect of the top PIT rate on the income distribution, pre-crisis

\begin{tabular}{|c|c|c|c|c|c|}
\hline Dependent variable & Income $^{q 1}$ & Income $^{q^{2}}$ & Income q3 $^{3}$ & Income $^{q 4}$ & Income q5 $^{5}$ \\
\hline $\ln \left(\text { income }^{\text {mean }}\right)_{t}$ & $\begin{array}{l}1.35^{\star * \star} \\
(0.19)\end{array}$ & $\begin{array}{l}1.33^{\star * *} \\
(0.049)\end{array}$ & $\begin{array}{l}1.26^{\star * *} \\
(0.048)\end{array}$ & $\begin{array}{l}1.11^{* * *} \\
(0.040)\end{array}$ & $\begin{array}{l}0.65^{\star \star \star} \\
(0.061)\end{array}$ \\
\hline$\Delta \ln \left(\text { income }^{\text {mean }}\right)_{t+1}$ & $\begin{array}{r}1.05 \\
(0.66)\end{array}$ & $\begin{array}{c}0.22 \\
(0.16)\end{array}$ & $\begin{array}{l}0.081 \\
(0.12)\end{array}$ & $\begin{array}{l}0.053 \\
(0.10)\end{array}$ & $\begin{array}{l}-0.29 \\
(0.19)\end{array}$ \\
\hline$\Delta \ln \left(\text { income }^{\text {mean }}\right)_{t}$ & $\begin{array}{r}0.29 \\
(0.34)\end{array}$ & $\begin{array}{l}-0.16 \\
(0.11)\end{array}$ & $\begin{array}{l}-0.22^{* *} \\
(0.097)\end{array}$ & $\begin{array}{l}-0.29^{\star \star \star} \\
(0.086)\end{array}$ & $\begin{array}{r}0.24^{*} \\
(0.13)\end{array}$ \\
\hline$\Delta \ln \left(\text { income }^{\text {mean }}\right)_{\mathrm{t}-1}$ & $\begin{array}{l}-0.090 \\
(0.37)\end{array}$ & $\begin{array}{c}-0.38^{* * *} \\
(0.14)\end{array}$ & $\begin{array}{c}-0.46^{\star * *} \\
(0.11)\end{array}$ & $\begin{array}{l}-0.18^{*} \\
(0.097)\end{array}$ & $\begin{array}{l}0.48^{* \star *} \\
(0.16)\end{array}$ \\
\hline $\begin{array}{l}\text { Underlying } \\
\text { primary spending }\end{array}$ & $\begin{array}{l}0.71^{* * *} \\
(0.20)\end{array}$ & $\begin{array}{c}0.12^{*} \\
(0.073)\end{array}$ & $\begin{array}{l}-0.23^{* *} \\
(0.097)\end{array}$ & $\begin{array}{l}-0.22^{\star \star *} \\
(0.078)\end{array}$ & $\begin{array}{l}0.028 \\
(0.10)\end{array}$ \\
\hline TMR use & $\begin{array}{l}14.0^{* \star \star} \\
(3.40)\end{array}$ & $\begin{array}{l}5.43^{\star * \star} \\
(1.00)\end{array}$ & $\begin{array}{l}2.02^{\star \star} \\
(0.86)\end{array}$ & $\begin{array}{l}-0.31 \\
(0.71)\end{array}$ & $\begin{array}{c}-5.37^{\star \star \star} \\
(0.97)\end{array}$ \\
\hline $\begin{array}{l}\text { Observations } \\
\mathrm{R}^{2}\end{array}$ & $\begin{array}{l}126 \\
0.610\end{array}$ & $\begin{array}{l}126 \\
0.927\end{array}$ & $\begin{array}{l}126 \\
0.935\end{array}$ & $\begin{array}{l}126 \\
0.942\end{array}$ & $\begin{array}{l}126 \\
0.796\end{array}$ \\
\hline
\end{tabular}

Note: The adjusted $\mathrm{R}$ squared does not incorporate the effect of country and year fixed effects. Asterisks $\left({ }^{*},{ }^{* *},{ }^{* \star *}\right)$ indicate the significance level $(10 \%, 5 \%, 1 \%)$ of the coefficients. Standard errors are robust to arbitrary heteroskedasticity and autocorrelation (HAC). See Appendix Table A3.1 for data coverage. 
Table A1.5. The effect of the top PIT rate on the income distribution, with a control for underlying primary revenues

\begin{tabular}{|c|c|c|c|c|c|}
\hline Dependent variable & Income $\mathrm{q}^{1}$ & Income $\mathrm{q}^{\mathrm{2}}$ & Income $\mathrm{q3}^{3}$ & Income $\mathrm{q4}^{4}$ & Income $^{q^{5}}$ \\
\hline $\ln \left(\text { income }^{\text {mean }}\right)_{t}$ & $\begin{array}{l}1.17^{* \star *} \\
(0.083)\end{array}$ & $\begin{array}{l}1.11^{\text {***}} \\
(0.037)\end{array}$ & $\begin{array}{l}1.04^{* * *} \\
(0.029)\end{array}$ & $\begin{array}{l}1.00^{* \star *} \\
(0.020)\end{array}$ & $\begin{array}{l}0.92^{\star \star \star} \\
(0.041)\end{array}$ \\
\hline$\Delta \ln \left(\text { income }^{\text {mean }}\right)_{t+1}$ & $\begin{array}{l}0.029 \\
(0.14)\end{array}$ & $\begin{array}{l}-0.037 \\
(0.070)\end{array}$ & $\begin{array}{l}-0.080^{*} \\
(0.043)\end{array}$ & $\begin{array}{l}-0.036 \\
(0.027)\end{array}$ & $\begin{array}{r}0.087 \\
(0.072)\end{array}$ \\
\hline$\Delta \ln \left(\text { income }^{\text {mean }}\right)_{t}$ & $\begin{array}{l}-0.092 \\
(0.15)\end{array}$ & $\begin{array}{l}-0.19^{* *} \\
(0.077)\end{array}$ & $\begin{array}{l}-0.12^{\star \star} \\
(0.050)\end{array}$ & $\begin{array}{l}-0.039 \\
(0.036)\end{array}$ & $\begin{array}{c}0.14^{*} \\
(0.077)\end{array}$ \\
\hline$\Delta \ln \left(\text { income }^{\text {mean }}\right)_{t-1}$ & $\begin{array}{l}0.083 \\
(0.14)\end{array}$ & $\begin{array}{l}-0.29^{* \star *} \\
(0.073)\end{array}$ & $\begin{array}{l}-0.19^{\star \star \star} \\
(0.058)\end{array}$ & $\begin{array}{l}-0.12^{\star \star \star} \\
(0.039)\end{array}$ & $\begin{array}{l}0.24^{\star \star \star} \\
(0.069)\end{array}$ \\
\hline $\begin{array}{l}\text { Underlying } \\
\text { primary revenues }\end{array}$ & $\begin{array}{l}0.59^{* *} \\
(0.24)\end{array}$ & $\begin{array}{l}0.31^{\star \star} \\
(0.12)\end{array}$ & $\begin{array}{c}0.10 \\
(0.083)\end{array}$ & $\begin{array}{l}-0.075 \\
(0.056)\end{array}$ & $\begin{array}{l}-0.22^{*} \\
(0.13)\end{array}$ \\
\hline TMR use & $\begin{array}{l}6.64^{* \star *} \\
(2.11)\end{array}$ & $\begin{array}{l}3.21^{* * *} \\
(0.84)\end{array}$ & $\begin{array}{l}2.24^{\star * *} \\
(0.52)\end{array}$ & $\begin{array}{l}1.32^{\star \star \star} \\
(0.40)\end{array}$ & $\begin{array}{c}-4.49^{\star \star *} \\
(0.87) \\
\end{array}$ \\
\hline $\begin{array}{l}\text { Observations } \\
\mathrm{R}^{2}\end{array}$ & $\begin{array}{l}297 \\
0.726 \\
\end{array}$ & $\begin{array}{l}297 \\
0.899 \\
\end{array}$ & $\begin{array}{l}297 \\
0.943 \\
\end{array}$ & $\begin{array}{l}297 \\
0.967\end{array}$ & $\begin{array}{l}297 \\
0.888 \\
\end{array}$ \\
\hline
\end{tabular}

Note: The adjusted $\mathrm{R}$ squared does not incorporate the effect of country and year fixed effects. Asterisks $\left({ }^{*},{ }^{* *},{ }^{* \star *}\right)$ indicate the significance level $(10 \%, 5 \%, 1 \%)$ of the coefficients. Standard errors are robust to arbitrary heteroskedasticity and autocorrelation (HAC). See Appendix Table A3.1 for data coverage.

Table A1.6. The effect of the average tax wedge on the income distribution: Robustness check with no lead variable

\begin{tabular}{|c|c|c|c|c|c|}
\hline Dependent variable & $\ln \left(\right.$ income $\left.\mathrm{q}^{\mathrm{q}}\right)$ & $\ln \left(\right.$ income $\left.\mathrm{q}^{\mathrm{2}}\right)$ & $\ln \left(\right.$ income $\left.\mathrm{q}^{\mathrm{3}}\right)$ & $\ln \left(\right.$ income $\left.\mathrm{q}^{4}\right)$ & $\ln \left(\right.$ income $\left.\mathrm{q}^{\mathrm{9}}\right)$ \\
\hline $\ln \left(\text { income }^{\text {mean }}\right)_{t}$ & $\begin{array}{l}1.15^{\star \star \star} \\
(0.087)\end{array}$ & $\begin{array}{l}1.00^{* * *} \\
(0.042)\end{array}$ & $\begin{array}{l}0.95^{\star * *} \\
(0.029)\end{array}$ & $\begin{array}{l}0.97^{* * *} \\
(0.020)\end{array}$ & $\begin{array}{l}1.01^{* * *} \\
(0.047)\end{array}$ \\
\hline$\Delta \ln \left(\text { income }^{\text {mean }}\right)_{\mathrm{t}}$ & $\begin{array}{l}-0.021 \\
(0.082)\end{array}$ & $\begin{array}{l}-0.065^{\star} \\
(0.039)\end{array}$ & $\begin{array}{l}-0.019 \\
(0.026)\end{array}$ & $\begin{array}{r}0.037 \\
(0.027)\end{array}$ & $\begin{array}{l}0.0062 \\
(0.043)\end{array}$ \\
\hline$\Delta \ln \left(\text { income }^{\text {mean }}\right)_{\mathrm{t}-1}$ & $\begin{array}{l}-0.13 \\
(0.12)\end{array}$ & $\begin{array}{l}-0.17^{* * *} \\
(0.059)\end{array}$ & $\begin{array}{l}-0.020 \\
(0.046)\end{array}$ & $\begin{array}{l}-0.044 \\
(0.034)\end{array}$ & $\begin{array}{c}0.12^{*} \\
(0.062)\end{array}$ \\
\hline $\begin{array}{l}\text { Underlying } \\
\text { primary spending }\end{array}$ & $\begin{array}{l}-0.029 \\
(0.10)\end{array}$ & $\begin{array}{l}-0.029 \\
(0.059)\end{array}$ & $\begin{array}{l}-0.091^{*} \\
(0.046)\end{array}$ & $\begin{array}{l}-0.039 \\
(0.040)\end{array}$ & $\begin{array}{c}0.070 \\
(0.068)\end{array}$ \\
\hline $\begin{array}{l}\text { Average tax wedge } \\
\text { ( } 67 \% \text { mean income) }\end{array}$ & $\begin{array}{l}-0.46^{*} \\
(0.25)\end{array}$ & $\begin{array}{l}-0.22^{*} \\
(0.12)\end{array}$ & $\begin{array}{l}-0.014 \\
(0.082)\end{array}$ & $\begin{array}{r}0.048 \\
(0.066)\end{array}$ & $\begin{array}{l}0.13 \\
(0.14)\end{array}$ \\
\hline $\begin{array}{l}\text { Average tax wedge } \\
\text { (167\% mean income) }\end{array}$ & $\begin{array}{l}0.64^{* * *} \\
(0.16)\end{array}$ & $\begin{array}{l}0.36^{* * *} \\
(0.095)\end{array}$ & $\begin{array}{l}-0.016 \\
(0.090)\end{array}$ & $\begin{array}{l}-0.15^{* *} \\
(0.071)\end{array}$ & $\begin{array}{l}-0.18 \\
(0.12)\end{array}$ \\
\hline Observations & 285 & 285 & 285 & 285 & 285 \\
\hline $\mathrm{R}^{2}$ & 0.696 & 0.879 & 0.939 & 0.965 & 0.893 \\
\hline
\end{tabular}

Note: The adjusted $\mathrm{R}$ squared does not incorporate the effect of country and year fixed effects. Asterisks $\left({ }^{*},{ }^{* *},{ }^{* \star *}\right)$ indicate the significance level $(10 \%, 5 \%, 1 \%)$ of the coefficients. Standard errors are robust to arbitrary heteroskedasticity and autocorrelation (HAC). See Appendix Table A3.1 for data coverage. 


\section{APPENDIX 2. ADDITIONAL RESULTS ON GROWTH}

Table A2.1. Growth regressions controlling for the total-tax-GDP ratio: Corporate income tax

\begin{tabular}{|c|c|c|c|c|c|c|}
\hline & $(1)$ & $(2)$ & $(3)$ & $(4)$ & $(5)$ & \\
\hline Explanatory variables (all lagged): & \multicolumn{6}{|c|}{ Dependent variable: Potential output growth per capita } \\
\hline \multicolumn{7}{|l|}{ Production function } \\
\hline Ln potential output per capita & $\begin{array}{c}-0.061^{* * *} \\
(0.014)\end{array}$ & $\begin{array}{c}-0.064^{* * *} \\
(0.015)\end{array}$ & $\begin{array}{c}-0.068^{\star * *} \\
(0.015)\end{array}$ & $\begin{array}{c}-0.056^{\star * *} \\
(0.015)\end{array}$ & $\begin{array}{c}-0.070^{* * *} \\
(0.014)\end{array}$ & $\begin{array}{c}-0.059^{* * *} \\
(0.014)\end{array}$ \\
\hline Ln physical investment & $\begin{array}{l}0.019^{* * *} \\
(0.0064)\end{array}$ & $\begin{array}{l}0.020^{* * *} \\
(0.0065)\end{array}$ & $\begin{array}{l}0.018^{* * *} \\
(0.0063)\end{array}$ & $\begin{array}{l}0.022^{\star * *} \\
(0.0068)\end{array}$ & & $\begin{array}{l}0.025^{\star * *} \\
(0.0067)\end{array}$ \\
\hline Ln human capital investment & $\begin{array}{c}0.13^{*} \\
(0.069)\end{array}$ & $\begin{array}{l}0.14^{\star *} \\
(0.067)\end{array}$ & $\begin{array}{l}0.16^{\star \star} \\
(0.063)\end{array}$ & $\begin{array}{l}0.19^{* * *} \\
(0.069)\end{array}$ & $\begin{array}{c}0.083 \\
(0.065)\end{array}$ & $\begin{array}{l}0.21^{* * *} \\
(0.058)\end{array}$ \\
\hline Working-age population growth & $\begin{array}{l}-0.28 \\
(0.24)\end{array}$ & $\begin{array}{l}-0.21 \\
(0.24)\end{array}$ & $\begin{array}{l}-0.28 \\
(0.24)\end{array}$ & $\begin{array}{l}-0.33 \\
(0.24)\end{array}$ & $\begin{array}{l}0.067 \\
(0.19)\end{array}$ & $\begin{array}{l}0.020 \\
(0.21)\end{array}$ \\
\hline \multicolumn{7}{|l|}{ Additional variables } \\
\hline Market potential & $\begin{array}{l}0.014^{* * *} \\
(0.0036)\end{array}$ & $\begin{array}{l}0.016^{* * *} \\
(0.0042)\end{array}$ & $\begin{array}{l}0.013^{\star * *} \\
(0.0040)\end{array}$ & $\begin{array}{l}0.011^{\star * *} \\
(0.0039)\end{array}$ & $\begin{array}{l}0.017^{* * *} \\
(0.0041)\end{array}$ & $\begin{array}{l}0.021^{\star * *} \\
(0.0028)\end{array}$ \\
\hline Inflation & $\begin{array}{l}-0.030 \\
(0.020)\end{array}$ & $\begin{array}{l}-0.030 \\
(0.020)\end{array}$ & $\begin{array}{l}-0.030 \\
(0.019)\end{array}$ & $\begin{array}{c}0.010 \\
(0.021)\end{array}$ & $\begin{array}{l}-0.034^{*} \\
(0.019)\end{array}$ & $\begin{array}{l}-0.041^{*} \\
(0.022)\end{array}$ \\
\hline Private credit to GDP & $\begin{array}{l}-0.0036^{*} \\
(0.0020)\end{array}$ & $\begin{array}{c}-0.0048^{* *} \\
(0.0020)\end{array}$ & $\begin{array}{c}-0.0040^{* *} \\
(0.0020)\end{array}$ & $\begin{array}{l}-0.0031 \\
(0.0023)\end{array}$ & $\begin{array}{l}-0.0050^{*} \\
(0.0026)\end{array}$ & $\begin{array}{l}-0.0030 * \\
(0.0016)\end{array}$ \\
\hline Old age dependency ratio & $\begin{array}{l}-0.048 \\
(0.036) \\
\end{array}$ & $\begin{array}{l}-0.030 \\
(0.042) \\
\end{array}$ & $\begin{array}{l}-0.016 \\
(0.039) \\
\end{array}$ & $\begin{array}{c}0.012 \\
(0.039) \\
\end{array}$ & $\begin{array}{l}-0.060 \\
(0.040) \\
\end{array}$ & $\begin{array}{c}-0.072^{\star * *} \\
(0.028) \\
\end{array}$ \\
\hline \multicolumn{7}{|l|}{ Government variables } \\
\hline Governance quality & $\begin{array}{c}0.0055^{\star * *} \\
(0.0019)\end{array}$ & $\begin{array}{c}0.0054^{* * *} \\
(0.0019)\end{array}$ & $\begin{array}{c}0.0048^{* * *} \\
(0.0018)\end{array}$ & $\begin{array}{l}0.0037^{* *} \\
(0.0016)\end{array}$ & $\begin{array}{c}0.0077^{* * *} \\
(0.0020)\end{array}$ & $\begin{array}{c}0.0068^{* * *} \\
(0.0018)\end{array}$ \\
\hline Government revenue ratio to GDP & $\begin{array}{c}0.019 \\
(0.022)\end{array}$ & $\begin{array}{l}0.0090 \\
(0.023)\end{array}$ & $\begin{array}{r}-0.0061 \\
(0.023)\end{array}$ & $\begin{array}{l}-0.026 \\
(0.024)\end{array}$ & $\begin{array}{l}0.0085 \\
(0.025)\end{array}$ & $\begin{array}{c}0.020 \\
(0.024)\end{array}$ \\
\hline Effective marginal CIT tax rate & $\begin{array}{l}-0.033^{\star \star} \\
(0.015)\end{array}$ & $\begin{array}{l}-0.027^{*} \\
(0.016)\end{array}$ & $\begin{array}{c}-0.035^{\star *} \\
(0.016)\end{array}$ & & $\begin{array}{l}-0.031^{*} \\
(0.016)\end{array}$ & $\begin{array}{c}-0.048^{\star *} \\
(0.019)\end{array}$ \\
\hline Top marginal PIT rate & & $\begin{array}{c}-0.014^{*} \\
(0.0083)\end{array}$ & $\begin{array}{l}-0.023^{\star *} \\
(0.0092)\end{array}$ & $\begin{array}{c}-0.031^{* * *} \\
(0.010)\end{array}$ & $\begin{array}{l}-0.018^{\star *} \\
(0.0082)\end{array}$ & \\
\hline VAT standard rate & & $\begin{array}{l}0.0066 \\
(0.041)\end{array}$ & $\begin{array}{l}-0.011 \\
(0.042)\end{array}$ & $\begin{array}{l}-0.0034 \\
(0.043)\end{array}$ & $\begin{array}{l}0.0060 \\
(0.043)\end{array}$ & \\
\hline Ratio of CIT receipts to GDP & & & $\begin{array}{l}0.17^{* \star *} \\
(0.052)\end{array}$ & $\begin{array}{l}0.21^{\star \star \star} \\
(0.064)\end{array}$ & & \\
\hline $\begin{array}{l}\text { Difference of domestic METR of CIT } \\
\text { and METR of CIT in other countries }\end{array}$ & & & & $\begin{array}{l}-0.024 \\
(0.016)\end{array}$ & & \\
\hline $\begin{array}{l}\text { CIT rate interacted with the PIT } \\
\text { dividend imputation rate }\end{array}$ & & & & & & $\begin{array}{l}0.0019^{* *} \\
(0.00083)\end{array}$ \\
\hline Observations & 528 & 491 & 491 & 436 & 491 & 446 \\
\hline Adjusted R-squared & 0.314 & 0.316 & 0.346 & 0.337 & 0.272 & 0.458 \\
\hline
\end{tabular}

Note: All regressions include country and year fixed effects. The dependent variable is the change in the logarithm of potential GDP per capita. Asterisks $\left({ }^{*},{ }^{\star *},{ }^{* \star \star}\right)$ indicate the significance level $(10 \%, 5 \%, 1 \%)$ of the coefficients. Standard errors are robust to arbitrary heteroskedasticity and autocorrelation (HAC). The adjusted R squared does not incorporate the effect of country and year fixed effects. See Appendix Table A3.1 for data coverage. 
Table A2.2. Growth regressions controlling for the total-tax-GDP ratio: Personal income tax

\begin{tabular}{|c|c|c|c|c|c|c|}
\hline & (1) & (2) & (3) & (4) & (5) & (6) \\
\hline Explanatory variables (all lagged): & \multicolumn{6}{|c|}{ Dependent variable: Potential output growth per capita } \\
\hline \multicolumn{7}{|l|}{ Production function } \\
\hline Ln potential output per capita & $\begin{array}{c}-0.054^{* * *} \\
(0.011)\end{array}$ & $\begin{array}{c}-0.052^{\star \star *} \\
(0.011)\end{array}$ & $\begin{array}{c}-0.057^{\star * *} \\
(0.011)\end{array}$ & $\begin{array}{c}-0.044^{* * *} \\
(0.013)\end{array}$ & $\begin{array}{c}-0.042^{\star * *} \\
(0.013)\end{array}$ & $\begin{array}{c}-0.049^{\star * *} \\
(0.013)\end{array}$ \\
\hline Ln physical investment & $\begin{array}{l}0.018^{\star * *} \\
(0.0062)\end{array}$ & $\begin{array}{l}0.018^{\star \star \star} \\
(0.0061)\end{array}$ & $\begin{array}{l}0.019^{\star * *} \\
(0.0062)\end{array}$ & $\begin{array}{l}0.028^{\star * *} \\
(0.0061)\end{array}$ & $\begin{array}{l}0.028^{\star * *} \\
(0.0060)\end{array}$ & $\begin{array}{l}0.028^{* * *} \\
(0.0061)\end{array}$ \\
\hline Ln human capital investment & $\begin{array}{l}0.16^{\star *} \\
(0.073)\end{array}$ & $\begin{array}{l}0.15^{\star *} \\
(0.072)\end{array}$ & $\begin{array}{l}0.17^{\star *} \\
(0.076)\end{array}$ & $\begin{array}{l}0.19^{* * *} \\
(0.067)\end{array}$ & $\begin{array}{l}0.19^{* * *} \\
(0.066)\end{array}$ & $\begin{array}{l}0.19^{\star \star *} \\
(0.073)\end{array}$ \\
\hline Working-age population growth & $\begin{array}{l}-0.35^{\star} \\
(0.20) \\
\end{array}$ & $\begin{array}{l}-0.32 \\
(0.21) \\
\end{array}$ & $\begin{array}{l}-0.37^{\star} \\
(0.23) \\
\end{array}$ & $\begin{array}{l}-0.48^{\star *} \\
(0.21) \\
\end{array}$ & $\begin{array}{l}-0.45^{\star *} \\
(0.22) \\
\end{array}$ & $\begin{array}{l}-0.52^{\star *} \\
(0.24)\end{array}$ \\
\hline \multicolumn{7}{|l|}{ Additional variables } \\
\hline Market potential & $\begin{array}{l}0.012^{* * *} \\
(0.0033)\end{array}$ & $\begin{array}{l}0.012^{* * *} \\
(0.0032)\end{array}$ & $\begin{array}{l}0.012^{* \star *} \\
(0.0033)\end{array}$ & $\begin{array}{l}0.010^{* * *} \\
(0.0035)\end{array}$ & $\begin{array}{l}0.010^{* * *} \\
(0.0034)\end{array}$ & $\begin{array}{c}0.0095^{* * *} \\
(0.0036)\end{array}$ \\
\hline Inflation & $\begin{array}{l}-0.014 \\
(0.017)\end{array}$ & $\begin{array}{l}-0.019 \\
(0.016)\end{array}$ & $\begin{array}{l}-0.0064 \\
(0.018)\end{array}$ & $\begin{array}{c}0.026 \\
(0.017)\end{array}$ & $\begin{array}{c}0.020 \\
(0.017)\end{array}$ & $\begin{array}{l}0.032^{*} \\
(0.018)\end{array}$ \\
\hline Private credit to GDP & $\begin{array}{l}-0.0062^{\star *} \\
(0.0031)\end{array}$ & $\begin{array}{l}-0.0061^{\star *} \\
(0.0030)\end{array}$ & $\begin{array}{c}-0.0062^{\star *} \\
(0.0029)\end{array}$ & $\begin{array}{l}-0.0048^{*} \\
(0.0026)\end{array}$ & $\begin{array}{l}-0.0047^{\star} \\
(0.0026)\end{array}$ & $\begin{array}{l}-0.0048^{*} \\
(0.0024)\end{array}$ \\
\hline Old age dependency ratio & $\begin{array}{l}-0.048 \\
(0.040) \\
\end{array}$ & $\begin{array}{l}-0.042 \\
(0.041) \\
\end{array}$ & $\begin{array}{l}-0.048 \\
(0.041) \\
\end{array}$ & $\begin{array}{l}0.0091 \\
(0.040)\end{array}$ & $\begin{array}{c}0.016 \\
(0.040)\end{array}$ & $\begin{array}{l}0.0062 \\
(0.041)\end{array}$ \\
\hline \multicolumn{7}{|l|}{ Government variables } \\
\hline Governance quality & $\begin{array}{c}0.0058^{* * *} \\
(0.0016)\end{array}$ & $\begin{array}{c}0.0053^{* * *} \\
(0.0016)\end{array}$ & $\begin{array}{c}0.0063^{* * *} \\
(0.0017)\end{array}$ & $\begin{array}{l}0.0029^{*} \\
(0.0016)\end{array}$ & $\begin{array}{c}0.0024 \\
(0.0016)\end{array}$ & $\begin{array}{l}0.0036^{* *} \\
(0.0017)\end{array}$ \\
\hline Government revenue ratio to GDP & $\begin{array}{c}0.020 \\
(0.022)\end{array}$ & $\begin{array}{c}0.019 \\
(0.022)\end{array}$ & $\begin{array}{c}0.026 \\
(0.023)\end{array}$ & $\begin{array}{l}0.0085 \\
(0.024)\end{array}$ & $\begin{array}{l}0.0051 \\
(0.024)\end{array}$ & $\begin{array}{c}0.013 \\
(0.025)\end{array}$ \\
\hline $\begin{array}{l}\text { Marginal tax wedge at } 67 \% \\
\text { of mean income }\end{array}$ & $\begin{array}{c}-0.051^{* * *} \\
(0.014)\end{array}$ & $\begin{array}{l}-0.056^{\star * *} \\
(0.015)\end{array}$ & & $\begin{array}{l}-0.054^{\star * *} \\
(0.015)\end{array}$ & $\begin{array}{l}-0.059^{* * *} \\
(0.016)\end{array}$ & \\
\hline $\begin{array}{l}\text { Marginal tax wedge } \\
\text { at mean income }\end{array}$ & & $\begin{array}{l}0.014^{\star *} \\
(0.0071)\end{array}$ & & & $\begin{array}{c}0.015^{*} \\
(0.0076)\end{array}$ & \\
\hline $\begin{array}{l}\text { Marginal tax wedge at } 167 \% \\
\text { of mean income }\end{array}$ & $\begin{array}{l}-0.029^{* *} \\
(0.012)\end{array}$ & $\begin{array}{l}-0.036^{\star \star *} \\
(0.012)\end{array}$ & & $\begin{array}{l}-0.021^{*} \\
(0.011)\end{array}$ & $\begin{array}{l}-0.029^{* * *} \\
(0.011)\end{array}$ & \\
\hline $\begin{array}{l}\text { Average tax wedge at } 167 \% \\
\text { of mean income }\end{array}$ & & & $\begin{array}{l}-0.078^{\star \star *} \\
(0.019)\end{array}$ & & & $\begin{array}{c}-0.069^{\star * *} \\
(0.019)\end{array}$ \\
\hline Effective marginal tax rate of $\mathrm{CIT}$ & & & & $\begin{array}{l}0.0028 \\
(0.016)\end{array}$ & $\begin{array}{l}0.0071 \\
(0.015)\end{array}$ & $\begin{array}{l}-0.0016 \\
(0.016)\end{array}$ \\
\hline VAT standard rate & & & & $\begin{array}{l}-0.0058 \\
(0.042) \\
\end{array}$ & $\begin{array}{l}-0.0019 \\
(0.041) \\
\end{array}$ & $\begin{array}{l}-0.0089 \\
(0.041) \\
\end{array}$ \\
\hline Observations & 481 & 481 & 481 & 431 & 431 & 431 \\
\hline R-squared & 0.363 & 0.370 & 0.335 & 0.378 & 0.386 & 0.338 \\
\hline
\end{tabular}

Note: All regressions include country and year fixed effects. The dependent variable is the change in the logarithm of potential GDP per capita. Asterisks $\left({ }^{*},{ }^{* *},{ }^{* * *}\right)$ indicate the significance level $(10 \%, 5 \%, 1 \%)$ of the coefficients. Standard errors are robust to arbitrary heteroskedasticity and autocorrelation (HAC). The adjusted R squared does not incorporate the effect of country and year fixed effects. See Appendix Table A3.1 for data coverage. 
Table A2.3. Growth regressions controlling for the total-tax-GDP ratio: Value added tax

\begin{tabular}{|c|c|c|c|c|}
\hline & (1) & (2) & (3) & (4) \\
\hline $\begin{array}{l}\text { Explanatory variables (all } \\
\text { lagged): }\end{array}$ & \multicolumn{4}{|c|}{ Dependent variable: Potential output growth per capita } \\
\hline \multicolumn{5}{|l|}{ Production function } \\
\hline $\begin{array}{l}\text { Ln potential output } \\
\text { per capita }\end{array}$ & $\begin{array}{l}-0.061^{\star * *} \\
(0.0093)\end{array}$ & $\begin{array}{l}-0.061^{* \star \star} \\
(0.0093)\end{array}$ & $\begin{array}{c}-0.061^{\star * *} \\
(0.014)\end{array}$ & $\begin{array}{c}-0.064^{* * *} \\
(0.015)\end{array}$ \\
\hline Ln physical investment & $\begin{array}{l}0.014^{* *} \\
(0.0061)\end{array}$ & $\begin{array}{l}0.014^{* *} \\
(0.0058)\end{array}$ & $\begin{array}{l}0.019^{\star * *} \\
(0.0063)\end{array}$ & $\begin{array}{l}0.020^{\star * *} \\
(0.0063)\end{array}$ \\
\hline $\begin{array}{l}\text { Ln human capital } \\
\text { investment }\end{array}$ & $\begin{array}{c}0.12^{*} \\
(0.063)\end{array}$ & $\begin{array}{c}0.12^{*} \\
(0.063)\end{array}$ & $\begin{array}{c}0.13^{*} \\
(0.069)\end{array}$ & $\begin{array}{l}0.14^{* *} \\
(0.067)\end{array}$ \\
\hline $\begin{array}{l}\text { Working-age population } \\
\text { growth }\end{array}$ & $\begin{array}{l}-0.25 \\
(0.21)\end{array}$ & $\begin{array}{l}-0.25 \\
(0.22)\end{array}$ & $\begin{array}{l}-0.27 \\
(0.25)\end{array}$ & $\begin{array}{l}-0.22 \\
(0.24)\end{array}$ \\
\hline \multicolumn{5}{|l|}{ Additional variables } \\
\hline Market potential & $\begin{array}{l}0.013^{* * *} \\
(0.0035)\end{array}$ & $\begin{array}{l}0.013^{* * *} \\
(0.0035)\end{array}$ & $\begin{array}{l}0.014^{* * *} \\
(0.0039)\end{array}$ & $\begin{array}{l}0.016^{* * *} \\
(0.0042)\end{array}$ \\
\hline Inflation & $\begin{array}{l}-0.033^{\star *} \\
(0.015)\end{array}$ & $\begin{array}{l}-0.033^{\star *} \\
(0.016)\end{array}$ & $\begin{array}{l}-0.029 \\
(0.021)\end{array}$ & $\begin{array}{l}-0.029 \\
(0.021)\end{array}$ \\
\hline Private credit to GDP & $\begin{array}{l}-0.0043^{*} \\
(0.0022)\end{array}$ & $\begin{array}{l}-0.0043^{*} \\
(0.0022)\end{array}$ & $\begin{array}{l}-0.0036^{*} \\
(0.0020)\end{array}$ & $\begin{array}{l}-0.0049^{* *} \\
(0.0020)\end{array}$ \\
\hline $\begin{array}{l}\text { Old age dependency } \\
\text { ratio }\end{array}$ & $\begin{array}{l}-0.058^{*} \\
(0.035)\end{array}$ & $\begin{array}{l}-0.057^{*} \\
(0.034)\end{array}$ & $\begin{array}{l}-0.048 \\
(0.037)\end{array}$ & $\begin{array}{l}-0.031 \\
(0.042)\end{array}$ \\
\hline \multicolumn{5}{|l|}{ Government variables } \\
\hline Governance quality & $\begin{array}{l}0.0070^{* * *} \\
(0.0018)\end{array}$ & $\begin{array}{l}0.0070^{* * *} \\
(0.0018)\end{array}$ & $\begin{array}{l}0.0055^{* * *} \\
(0.0019)\end{array}$ & $\begin{array}{l}0.0054^{* * *} \\
(0.0019)\end{array}$ \\
\hline $\begin{array}{l}\text { Government revenue } \\
\text { ratio to GDP }\end{array}$ & $\begin{array}{c}0.023 \\
(0.019)\end{array}$ & $\begin{array}{c}0.024 \\
(0.020)\end{array}$ & $\begin{array}{c}0.022 \\
(0.023)\end{array}$ & $\begin{array}{l}0.0068 \\
(0.024)\end{array}$ \\
\hline VAT standard rate & $\begin{array}{l}-0.051 \\
(0.045)\end{array}$ & $\begin{array}{l}-0.051 \\
(0.046)\end{array}$ & $\begin{array}{l}-0.0043 \\
(0.045)\end{array}$ & $\begin{array}{l}0.0035 \\
(0.043)\end{array}$ \\
\hline $\begin{array}{l}\text { Ratio of VAT receipts } \\
\text { to GDP }\end{array}$ & & $\begin{array}{l}-0.0048 \\
(0.074)\end{array}$ & $\begin{array}{l}-0.020 \\
(0.073)\end{array}$ & $\begin{array}{c}0.023 \\
(0.082)\end{array}$ \\
\hline $\begin{array}{l}\text { CIT effective } \\
\text { marginal rate }\end{array}$ & & & $\begin{array}{c}-0.034^{* *} \\
(0.015)\end{array}$ & $\begin{array}{l}-0.027^{*} \\
(0.016)\end{array}$ \\
\hline PIT top marginal rate & & & & $\begin{array}{c}-0.013 \\
(0.0089)\end{array}$ \\
\hline Observations & 567 & 567 & 508 & 491 \\
\hline R-squared & 0.319 & 0.319 & 0.313 & 0.316 \\
\hline
\end{tabular}

Note: All regressions include country and year fixed effects. The dependent variable is the change in the logarithm of potential GDP per capita. Asterisks $\left({ }^{*},{ }^{* *},{ }^{* \star *}\right)$ indicate the significance level $(10 \%, 5 \%, 1 \%)$ of the coefficients. Standard errors are robust to arbitrary heteroskedasticity and autocorrelation (HAC). The adjusted R squared does not incorporate the effect of country and year fixed effects. See Appendix Table A3.1 for data coverage. 
ECO/WKP(2017)79

Table A2.4. Growth regressions controlling for the total-tax-GDP ratio: Environmental and property taxes

\begin{tabular}{|c|c|c|c|c|c|c|c|}
\hline & (1) & (2) & (3) & (4) & (5) & (6) & (7) \\
\hline Explanatory variables (all lagged): & \multicolumn{7}{|c|}{ Dependent variable: Potential output growth per capita } \\
\hline \multicolumn{8}{|l|}{ Production function } \\
\hline Ln potential output per capita & $\begin{array}{c}-0.064^{* * *} \\
(0.017)\end{array}$ & $\begin{array}{c}-0.066^{* * *} \\
(0.017)\end{array}$ & $\begin{array}{c}-0.061^{* * *} \\
(0.014)\end{array}$ & $\begin{array}{c}-0.065^{\star * *} \\
(0.014)\end{array}$ & $\begin{array}{c}-0.067^{* * *} \\
(0.014)\end{array}$ & $\begin{array}{c}-0.064^{* * *} \\
(0.014)\end{array}$ & $\begin{array}{c}-0.064^{* * *} \\
(0.014)\end{array}$ \\
\hline Ln physical investment & $\begin{array}{l}0.020^{\star * *} \\
(0.0068)\end{array}$ & $\begin{array}{l}0.021^{* * *} \\
(0.0064)\end{array}$ & $\begin{array}{l}0.024^{* * *} \\
(0.0062)\end{array}$ & $\begin{array}{l}0.020^{\star * *} \\
(0.0058)\end{array}$ & $\begin{array}{l}0.022^{* * *} \\
(0.0059)\end{array}$ & $\begin{array}{l}0.022^{* * *} \\
(0.0059)\end{array}$ & $\begin{array}{l}0.021^{* * *} \\
(0.0061)\end{array}$ \\
\hline Ln human capital investment & $\begin{array}{c}0.13^{*} \\
(0.073)\end{array}$ & $\begin{array}{c}0.11 \\
(0.070)\end{array}$ & $\begin{array}{c}0.12^{*} \\
(0.065)\end{array}$ & $\begin{array}{c}0.13^{*} \\
(0.066)\end{array}$ & $\begin{array}{l}0.15^{\star \star} \\
(0.065)\end{array}$ & $\begin{array}{c}0.12^{*} \\
(0.065)\end{array}$ & $\begin{array}{c}0.11^{*} \\
(0.064)\end{array}$ \\
\hline Working-age population growth & $\begin{array}{l}-0.17 \\
(0.24) \\
\end{array}$ & $\begin{array}{l}-0.19 \\
(0.24) \\
\end{array}$ & $\begin{array}{l}-0.21 \\
(0.23) \\
\end{array}$ & $\begin{array}{l}-0.30 \\
(0.21) \\
\end{array}$ & $\begin{array}{l}-0.28 \\
(0.23) \\
\end{array}$ & $\begin{array}{l}-0.24 \\
(0.23) \\
\end{array}$ & $\begin{array}{l}-0.24 \\
(0.23) \\
\end{array}$ \\
\hline \multicolumn{8}{|l|}{ Additional variables } \\
\hline Market potential & $\begin{array}{l}0.015^{* * *} \\
(0.0040)\end{array}$ & $\begin{array}{l}0.015^{\star * *} \\
(0.0041)\end{array}$ & $\begin{array}{l}0.016^{\star * *} \\
(0.0040)\end{array}$ & $\begin{array}{l}0.017^{* * *} \\
(0.0038)\end{array}$ & $\begin{array}{l}0.017^{* * *} \\
(0.0040)\end{array}$ & $\begin{array}{l}0.015^{\star * *} \\
(0.0039)\end{array}$ & $\begin{array}{l}0.015^{* * *} \\
(0.0038)\end{array}$ \\
\hline Inflation & $\begin{array}{l}-0.028 \\
(0.021)\end{array}$ & $\begin{array}{l}-0.028 \\
(0.021)\end{array}$ & $\begin{array}{l}-0.032 \\
(0.019)\end{array}$ & $\begin{array}{l}-0.039^{* *} \\
(0.019)\end{array}$ & $\begin{array}{l}-0.033^{*} \\
(0.020)\end{array}$ & $\begin{array}{l}-0.030 \\
(0.020)\end{array}$ & $\begin{array}{l}-0.032 \\
(0.020)\end{array}$ \\
\hline Private credit to GDP & $\begin{array}{l}-0.0044^{\star *} \\
(0.0020)\end{array}$ & $\begin{array}{c}-0.0051^{\star * *} \\
(0.0019)\end{array}$ & $\begin{array}{c}-0.0057^{\star \star *} \\
(0.0018)\end{array}$ & $\begin{array}{c}-0.0061^{* * *} \\
(0.0018)\end{array}$ & $\begin{array}{c}-0.0048^{* * *} \\
(0.0018)\end{array}$ & $\begin{array}{c}-0.0054^{\star \star *} \\
(0.0019)\end{array}$ & $\begin{array}{c}-0.0053^{\star * *} \\
(0.0019)\end{array}$ \\
\hline Old age dependency ratio & $\begin{array}{r}-0.0047 \\
(0.042) \\
\end{array}$ & $\begin{array}{l}-0.019 \\
(0.044) \\
\end{array}$ & $\begin{array}{l}-0.028 \\
(0.043) \\
\end{array}$ & $\begin{array}{l}-0.044 \\
(0.041) \\
\end{array}$ & $\begin{array}{l}-0.040 \\
(0.040) \\
\end{array}$ & $\begin{array}{l}-0.037 \\
(0.041) \\
\end{array}$ & $\begin{array}{l}-0.036 \\
(0.041) \\
\end{array}$ \\
\hline \multicolumn{8}{|l|}{ Government variables } \\
\hline Governance Quality & $\begin{array}{l}0.0050^{\star *} \\
(0.0020)\end{array}$ & $\begin{array}{l}0.0047^{* *} \\
(0.0020)\end{array}$ & $\begin{array}{l}0.0046^{\star *} \\
(0.0018)\end{array}$ & $\begin{array}{c}0.0045^{\star \star *} \\
(0.0017)\end{array}$ & $\begin{array}{l}0.0040^{* *} \\
(0.0018)\end{array}$ & $\begin{array}{c}0.0048^{* \star *} \\
(0.0018)\end{array}$ & $\begin{array}{c}0.0047^{* * *} \\
(0.0018)\end{array}$ \\
\hline Government revenue ratio to GDP & $\begin{array}{c}-0.0078 \\
(0.021)\end{array}$ & $\begin{array}{c}0.014 \\
(0.025)\end{array}$ & $\begin{array}{c}0.026 \\
(0.026)\end{array}$ & $\begin{array}{c}0.031 \\
(0.026)\end{array}$ & $\begin{array}{c}0.026 \\
(0.026)\end{array}$ & $\begin{array}{c}0.029 \\
(0.026)\end{array}$ & $\begin{array}{c}0.034 \\
(0.027)\end{array}$ \\
\hline PIT top marginal rate & $\begin{array}{l}-0.023 \\
(0.015)\end{array}$ & $\begin{array}{l}-0.021 \\
(0.014)\end{array}$ & $\begin{array}{l}-0.019 \\
(0.015)\end{array}$ & $\begin{array}{l}-0.016 \\
(0.014)\end{array}$ & $\begin{array}{l}-0.021 \\
(0.014)\end{array}$ & $\begin{array}{l}-0.022 \\
(0.015)\end{array}$ & $\begin{array}{l}-0.019 \\
(0.015)\end{array}$ \\
\hline CIT effective marginal rate & $\begin{array}{c}-0.010 \\
(0.0084)\end{array}$ & $\begin{array}{c}-0.014 \\
(0.0088)\end{array}$ & $\begin{array}{c}-0.015^{\star} \\
(0.0083)\end{array}$ & $\begin{array}{l}-0.016^{*} \\
(0.0087)\end{array}$ & $\begin{array}{l}-0.017^{\star *} \\
(0.0083)\end{array}$ & $\begin{array}{l}-0.016^{*} \\
(0.0084)\end{array}$ & $\begin{array}{l}-0.016^{\star *} \\
(0.0083)\end{array}$ \\
\hline Property tax receipts (ratio to GDP) & & $\begin{array}{l}-0.29^{*} \\
(0.15)\end{array}$ & $\begin{array}{c}-0.50^{\star * *} \\
(0.19)\end{array}$ & $\begin{array}{l}-0.10 \\
(0.13)\end{array}$ & $\begin{array}{l}-0.43^{* *} \\
(0.17)\end{array}$ & $\begin{array}{l}-0.29^{*} \\
(0.16)\end{array}$ & $\begin{array}{l}-0.38^{* *} \\
(0.15)\end{array}$ \\
\hline $\begin{array}{l}\text { Environmental tax receipts } \\
\text { (ratio to GDP) }\end{array}$ & $\begin{array}{l}0.071 \\
(0.16)\end{array}$ & $\begin{array}{l}0.068 \\
(0.15)\end{array}$ & & & & & \\
\hline $\begin{array}{l}\text { Recurrent taxes } \\
\text { on immovable property }\end{array}$ & & & $\begin{array}{l}0.57^{* *} \\
(0.29)\end{array}$ & & & & \\
\hline Recurrent taxes on net wealth & & & & $\begin{array}{l}-1.11^{* *} \\
(0.47)\end{array}$ & & & \\
\hline Estate, inheritance and gift taxes & & & & & $\begin{array}{l}1.98^{* *} \\
(0.81)\end{array}$ & & \\
\hline $\begin{array}{l}\text { Taxes on financial } \\
\text { and capital transactions }\end{array}$ & & & & & & $\begin{array}{r}-0.070 \\
(0.30)\end{array}$ & \\
\hline $\begin{array}{l}\text { Other non-recurrent taxes } \\
\text { on property }\end{array}$ & & & & & & & $\begin{array}{l}0.72^{* *} \\
(0.29)\end{array}$ \\
\hline Observations & 472 & 472 & 511 & 511 & 511 & 511 & 511 \\
\hline R-squared & 0.329 & 0.340 & 0.340 & 0.355 & 0.347 & 0.332 & 0.338 \\
\hline
\end{tabular}

Note: All regressions include country and year fixed effects. The dependent variable is the change in the logarithm of potential GDP per capita. Asterisks $\left({ }^{*},{ }^{* *},{ }^{* * *}\right)$ indicate the significance level $(10 \%, 5 \%, 1 \%)$ of the coefficients. Standard errors are robust to arbitrary heteroskedasticity and autocorrelation (HAC). The adjusted R squared does not incorporate the effect of country and year fixed effects. See Appendix Table A3.1 for data coverage. 
Table A2.5. Growth regression robustness check: PMG results

\begin{tabular}{|c|c|c|c|c|}
\hline & (1) & (2) & (3) & (4) \\
\hline & \multicolumn{2}{|c|}{$\begin{array}{l}\text { Tax items as share } \\
\text { of total tax revenue }\end{array}$} & \multicolumn{2}{|c|}{ Tax items as share of GDP } \\
\hline \multicolumn{5}{|l|}{ Production function } \\
\hline Ln output per capita & $\begin{array}{l}-0.26^{\star \star *} \\
(0.032)\end{array}$ & $\begin{array}{l}-0.26^{\star \star \star} \\
(0.031)\end{array}$ & $\begin{array}{l}-0.25^{\star \star \star} \\
(0.032)\end{array}$ & $\begin{array}{l}-0.25^{\star \star \star} \\
(0.031)\end{array}$ \\
\hline Ln physical investment & $\begin{array}{l}0.17^{\star * *} \\
(0.026)\end{array}$ & $\begin{array}{l}0.18^{\star * *} \\
(0.026)\end{array}$ & $\begin{array}{l}0.16^{\star * \star} \\
(0.026)\end{array}$ & $\begin{array}{l}0.16^{\star \star *} \\
(0.026)\end{array}$ \\
\hline Working age population growth & $\begin{array}{l}-0.35 \\
(1.11)\end{array}$ & $\begin{array}{l}-0.48 \\
(1.12)\end{array}$ & $\begin{array}{l}-0.55 \\
(1.12)\end{array}$ & $\begin{array}{l}-0.77 \\
(1.13)\end{array}$ \\
\hline Ln human capital investment & $\begin{array}{l}2.18^{* * *} \\
(0.096)\end{array}$ & $\begin{array}{l}2.19^{\star \star \star} \\
(0.098)\end{array}$ & $\begin{array}{l}2.15^{\star \star \star} \\
(0.092)\end{array}$ & $\begin{array}{l}2.15^{\star \star *} \\
(0.093)\end{array}$ \\
\hline \multicolumn{5}{|l|}{ Government variables } \\
\hline Total tax to GDP & $\begin{array}{l}0.066 \\
(0.16)\end{array}$ & $\begin{array}{c}0.12 \\
(0.16)\end{array}$ & $\begin{array}{c}0.98^{\star \star \star} \\
(0.36)\end{array}$ & $\begin{array}{l}-0.23 \\
(0.17)\end{array}$ \\
\hline Income taxes & $\begin{array}{l}-0.24^{*} \\
(0.13)\end{array}$ & & $\begin{array}{c}-1.20^{\star * *} \\
(0.42)\end{array}$ & \\
\hline Consumption and property taxes & & $\begin{array}{l}0.31^{* *} \\
(0.13)\end{array}$ & & $\begin{array}{c}1.37^{* * *} \\
(0.41)\end{array}$ \\
\hline Observations & 1256 & 1256 & 1256 & 1256 \\
\hline
\end{tabular}

Note: Asterisks $\left({ }^{*},{ }^{* *},{ }^{* * *}\right)$ indicate the significance level $(10 \%, 5 \%, 1 \%)$ of the coefficients. Standard errors are robust to between country heteroskedasticity. The regression s include country fixed effects. Short-term controls are not shown for brevity. See Appendix Table A3.1 for data coverage. 


\section{APPENDIX 3. DATA COVERAGE}

Table A3.1 Country and time coverage of main variables

\begin{tabular}{|c|c|c|c|c|c|c|}
\hline Country & $\begin{array}{l}\text { CIT marginal } \\
\text { effective rate }\end{array}$ & $\begin{array}{c}\text { PIT top } \\
\text { marginal rate }\end{array}$ & $\begin{array}{l}\text { VAT statutory } \\
\text { rate }\end{array}$ & $\begin{array}{c}\text { Labour } \\
\text { tax } \\
\text { wedges }\end{array}$ & $\begin{array}{l}\text { Property } \\
\text { tax } \\
\text { receipts }\end{array}$ & $\begin{array}{c}\text { Environmental } \\
\text { tax receipts }\end{array}$ \\
\hline AUS & $1988-2014$ & $1981-2014$ & $2000-2014$ & $2000-2014$ & $1980-2014$ & $1994-2013$ \\
\hline AUT & $1994-2014$ & $1981-2014$ & $1973-2014$ & $2000-2014$ & $1980-2014$ & $1994-2013$ \\
\hline BEL & 1994-2014 & $1981-2014$ & $1971-2014$ & $2000-2014$ & $1980-2014$ & $1994-2013$ \\
\hline CAN & $1999-2014$ & $1981-2014$ & $1991-2014$ & $2000-2014$ & $1980-2014$ & $1994-2013$ \\
\hline CHE & $1994-2014$ & $1981-2014$ & $1995-2014$ & $2000-2014$ & $1980-2014$ & $1994-2013$ \\
\hline $\mathrm{CHL}$ & $1996-2014$ & $2000-2014$ & $1975-2014$ & $2000-2014$ & $1990-2014$ & \\
\hline CZE & $2002-2014$ & $1993-2014$ & $1993-2014$ & $2000-2014$ & $1997-2014$ & $1994-2013$ \\
\hline DEU & $1990-2014$ & $1981-2014$ & $1968-2014$ & $2000-2014$ & $1980-2014$ & $1994-2013$ \\
\hline DNK & $1992-2014$ & $1981-2014$ & $1967-2014$ & $2000-2014$ & $1980-2014$ & $1994-2013$ \\
\hline ESP & $1996-2014$ & $1981-2014$ & $1986-2014$ & $2000-2014$ & $1980-2014$ & $1994-2013$ \\
\hline EST & $1994-2014$ & $2000-2014$ & 1992-2014 & $2000-2014$ & $2000-2014$ & $1995-2013$ \\
\hline FIN & $1992-2014$ & $2000-2014$ & $1994-2014$ & $2000-2014$ & $1980-2014$ & $1994-2013$ \\
\hline FRA & $1990-2014$ & $1981-2014$ & $1968-2014$ & $2000-2014$ & $1980-2014$ & $1994-2013$ \\
\hline GBR & $1990-2014$ & $1981-2014$ & $1973-2014$ & $2000-2014$ & $1980-2014$ & $1994-2013$ \\
\hline GRC & $1998-2014$ & $1981-2014$ & $1987-2014$ & $2000-2014$ & $1985-2014$ & $1994-2013$ \\
\hline HUN & $1994-2014$ & $1989-2014$ & $1988-2014$ & $2000-2014$ & $1996-2014$ & $1995-2013$ \\
\hline IRL & $1994-2014$ & $1981-2014$ & $1972-2014$ & $2000-2014$ & $1986-2014$ & $1994-2013$ \\
\hline ISL & $1995-2014$ & $2000-2014$ & $1990-2014$ & $2000-2014$ & $1980-2014$ & $1994-2013$ \\
\hline ISR & $1998-2014$ & $2000-2014$ & $1976-2014$ & $2000-2014$ & $1995-2014$ & $1995-2013$ \\
\hline ITA & $1990-2011$ & $1981-2014$ & $1973-2014$ & $2000-2014$ & $1980-2014$ & $1994-2013$ \\
\hline JPN & $1983-2014$ & $2000-2014$ & $1989-2014$ & $2000-2014$ & $1980-2014$ & $1994-2013$ \\
\hline KOR & $1999-2014$ & $2000-2014$ & $1977-2014$ & $2000-2014$ & $1980-2014$ & $1994-2013$ \\
\hline LUX & $1999-2014$ & $2000-2014$ & $1970-2014$ & $2000-2014$ & $1996-2014$ & $1994-2013$ \\
\hline LVA & & & $2000-2014$ & $2000-2014$ & $1996-2014$ & \\
\hline MEX & $1999-2014$ & $1981-2014$ & $1980-2014$ & $2000-2014$ & $1995-2014$ & 2003-2013 \\
\hline NLD & $1998-2014$ & $1981-2014$ & $1969-2014$ & $2000-2014$ & $1980-2014$ & $1994-2013$ \\
\hline NOR & $1992-2014$ & $1981-2014$ & $1970-2014$ & $2000-2014$ & $1980-2014$ & $1994-2013$ \\
\hline NZL & $1999-2014$ & $1981-2014$ & $1987-2014$ & $2000-2014$ & $1989-2014$ & $1994-2013$ \\
\hline POL & $1994-2014$ & $1992-2014$ & $1993-2014$ & $2000-2014$ & $1997-2014$ & $1995-2013$ \\
\hline PRT & $1994-2014$ & $1981-2014$ & $1986-2014$ & $2000-2014$ & $1980-2014$ & $1994-2013$ \\
\hline SVK & & $1993-2014$ & $1993-2014$ & $2000-2014$ & $1996-2014$ & $1995-2013$ \\
\hline SVN & $1995-2014$ & $2000-2014$ & $1999-2014$ & $2000-2014$ & $1999-2014$ & $1995-2013$ \\
\hline SWE & $1992-2014$ & $1981-2014$ & $1969-2014$ & $2000-2014$ & $1980-2014$ & $1994-2013$ \\
\hline TUR & $1998-2014$ & $2000-2014$ & $1985-2014$ & $2000-2014$ & $1995-2014$ & $2006-2011$ \\
\hline USA & $1999-2014$ & $1981-2014$ & & $2000-2014$ & $1980-2014$ & $1994-2013$ \\
\hline
\end{tabular}




\section{REFERENCES}

Acosta-Ormaechea, S. and J. Yoo (2012), “Tax Composition and Growth: A Broad Cross-Country Perspective”, IMF Working Paper, WP/12/257.

Akgun, O. and S. Dougherty (2018), "Globalisation, Decentralisation and Inclusive Growth,"Chapter 2 in OECD (2018), "Inclusive Growth and Decentralisation," OECD Publishing, forthcoming.

Akgun, O., D. Bartolini and B. Cournède (2017), "The Capacity of Government to Raise Taxes," OECD Economics Department Working Paper, No. 1407, OECD Publishing, Paris.

Albrizio, S., T. Kozluk and V. Zipperer (2014), "Empirical Evidence of the Effects of Environmental Policy Stringency on Productivity Growth," OECD Economics Department Working Papers, No. 1179, OECD Publishing, Paris..

Arnold, J.M. et al. (2011), “Tax Policy for Economic Recovery and Growth,” The Economic Journal, Vol. 121, pp. F59-F80.

Auerbach, A., L. Kotlikoff and D. Koehler (2016), "US Inequality, Fiscal Progressivity, and Work Disincentives: an Intragenerational Accounting," NBER Working Papers, No. 22032.

Barro, R. and J.-W. Lee (2013), “A New Data Set of Educational Attainment in the World, 1950-2010”, Journal of Development Economics, Vol. 104, pp. 184-198.

Bartolini, D. (2018), "Firms at the Productivity Frontier Enjoy Lower Effective Taxation", OECD Economics Department Working Papers, forthcoming.

Bloch, D., J.-M. Fournier, D. Gonzales and A. Pina (2016), “Trends in Public Finance: Insights from a New Detailed Dataset," OECD Economics Department Working Papers, No. 1345, OECD Publishing, Paris.

Blöchliger, H. (2015), "Reforming the Tax on Immovable Property: Taking Care of the Unloved", OECD Economics Department Working Papers, No. 1205, OECD Publishing, Paris.

Boadway, R., E. Chamberlain and C. Emmerson. (2009), "Taxation of Wealth and Wealth Transfers," in Adam, S. et al. (ed.), Dimensions of Tax Design, Oxford University Press.

Brys, B., S. Perret, T. Alastair and P. O’Reilly (2016), "Tax Design for Inclusive Economic Growth,” OECD Taxation Working Papers, No. 26, OECD Publishing, Paris.

Causa, O. and M. Hermansen (2017), "Income Redristribution through Taxes and Transfers across OECD Countries", OECD Economics Department Working Papers, OECD Publishing, forthcoming. 
CBT (2016), “Tax Database: Data Description,” Oxford Centre for Business Taxation (CBT), Oxford University, downloaded on 19 September 2017 from http://bit.ly/2xtXmeo.

Cronin, J. A., E. Lin, L. Power and M. Cooper (2013), "Distributing the Corporate Income Tax: Revised US Treasury Methodology”, National Tax Journal, Vol. 66, pp. 239-262.

Decoster, A., J. Loughrey, C. O’Donoghue and D. Verwerft (2010), "How Regressive Are Indirect Taxes? A Microsimulation Analysis for Five European Countries," Journal of Policy Analysis and Management, Vol. 29 Issue 2.

Decoster A. J., C. Loughrey, O’Donoghue and D. Verwerft (2011), "Microsimulation of Indirect Taxes", International Journal of Microsimulation, 4(2), pp 41-56.

Diamond, P.A. and J.A. Mirrlees (1971), "Optimal Taxation and Public Production", American Economic Review, Vol. 61.

Diamond P.A. and E. Saez (2011), "The Case for a Progressive Tax: From Basic Research to Policy Recommendations", Journal of Economic Perspectives, Vol. 25, Issue 4, pp. 165-190.

Drucker, L., Z. Krill and A. Geva (2017), “The Impact of Tax Composition on Income Inequality and Economic Growth", mimeo, August.

Ederveen, S. and R. de Mooij (2003), "To Which Rate Does Investment Respond? A Synthesis of Empirical Research on Taxation and Foreign Direct Investment”, in Tax Policy, Banca d'Italia.

Finkelstein, M. M., M. Jerrett, P. DeLuca, N. Finkelstein, D. Verma, K. Chapman and M. Sears (2003), "Relation Between Income, Air Pollution and Mortality: a Cohort Study", Canadian Medical Association Journal, Vol. 169, Issue 5, pp. 397-402.

Flues, F. and A. Thomas (2015), "The Distributional Effects of Energy Taxes”, OECD Taxation Working Papers, No. 23, OECD Publishing, Paris.

Fournier, J.-M. (2015); “The Negative Effect of Regulatory Divergence on Foreign Direct Investment”, OECD Economics Department Working Paper, No. 1268, OECD Publishing, Paris.

Fournier, J. M. and A. Johansson (2016), "The Effect of the Size and the Mix of Public Spending on Growth and Inequality", OECD Economics Department Working Papers, No. 1344, OECD Publishing, Paris.

Furman, J. and P. Orszag (2015), “A Firm-Level Perspective on the Role of Rents in the Rise in Inequality", Presentation at A Just Society: Centennial Event in Honour of Joseph Stiglitz, Columbia University.

Gal, P. (2013), "Measuring Total Factor Productivity at the Firm Level using OECD-ORBIS", OECD Economics Department Working Papers, No. 1049, OECD Publishing, Paris.

Galindo, A. J., and C. Pombo (2011), "Corporate Taxation, Investment and Productivity: A Firm Level Estimation," Journal of Accounting and Taxation, Vol. 5, Issue 7, pp. 158-161.

Gemmell, N., R. Kneller and I. Sanz (2011), "The Timing and Persistence of Fiscal Policy Impacts on Growth: Evidence from OECD Countries", The Economic Journal, Vol. 121, pp. F33-F58. 
Gemmell, N., Kneller, R. and I. Sanz (2014), "The Growth Effects of Tax Rates in the OECD”, Canadian Journal of Economics, Vol. 47, pp. 1-39.

Hajkova, D., G. Nicoletti, L. Vartia and K. Yoo (2007), "Taxation and Business Environment as Drivers of Foreign Direct Investment in OECD Countries," OECD Economic Studies, Issue 43, Vol. 2, OECD Publishing, Paris.

Harberger, A.C. (1962), "The Incidence of the Corporation Income Tax", Journal of Political Economy, Vol. 70, pp. 215-240.

Hermansen, M., N. Ruiz and O. Causa (2016), "The Distribution of the Growth Dividends," OECD Economics Department Working Papers, No. 1343, OECD Publishing, Paris.

Inchauste, G. and N. Lustig Ed. (2017), The Distributional Impact of Taxes and Transfers: Evidence from Eight Low and Middle-Income Countries, World Bank Group.

Johansson, Å. (2016), "Public Finance, Economic Growth and Inequality: A Survey of the Evidence" OECD Economics Department Working Papers, No. 1346, OECD Publishing, Paris.

Johansson, Å., Ø. Bieltvedt Skeie, S. Sorbe and C. Menon (2017), “Tax Planning by Multinational Firms”, OECD Economics Department Working Papers, No. 1355, OECD Publishing, Paris.

Joumard, I., M. Pisu and D. Bloch (2012), "Tackling Income Inequality: The Role of Taxes and Transfers", OECD Journal: Economic Studies.

Kao, C., M. H. Chiang and B. Chen (1999), "International R\&D Spillovers: an Application of Estimation and Inference in Panel Cointegration", Oxford Bulletin of Economics and Statistics, Vol. 61, No. S1, pp. 691-709.

Kaplow, L. (2008), The Theory of Taxation and Public Economics, Princeton University Press, Princeton.

Kneller, R., M. Bleaney and N. Gemmell (1999), "Fiscal Policy and Growth: Evidence from OECD Countries", Journal of Public Economics, Elsevier, Vol. 74(2).

Krugman, P. (1992), “A Dynamic Spatial Model”, NBER Working Paper No. 4219.

McNabb, K. and P. LeMay-Boucher (2014), “Tax Structures, Economic Growth and Development”, ICTD Working Paper, No. 22.

Mankiw, G.N., D. Romer and D. N. Weil (1992), "A Contribution to the Empirics of Economic Growth", Quarterly Journal of Economics, Vol. 107, pp. 407-437.

Mankiw, G. N., C. Weinzierl and D. F. Yagan (2009), "Optimal Taxation in Theory and Practice," Journal of Economic Perspectives, Vol. 23, Issue 4, pp. 147-174.

Mirrlees, J. A. (1971), “An Exploration in the Theory of Optimal Taxation”, Review of Economic Studies, Vol. 38, pp. 175-208.

Mirrlees, J. A. (1986), “The Theory of Optimal Taxation”, in K. J. Arrow and M.D. Intriligator (ed.), Handbook of Mathematical Economics, Vol. 3, Chapter 24, pp. 1197-1249, North Holland, Amsterdam. 
Mirrlees, J. A. et al. (2011), Tax by Design, Oxford University Press.

Mutti, J. and H. Grubert (1985), "The Taxation of Capital Income in an Open Economy: the Importance of Resident-nonresident Tax Treatment”, Journal of Public Economics, Vol. 27, pp. 291-309.

Myles, G. D. (2009a), "Economic Growth and the Role of Taxation - Theory," OECD Economics Department Working Papers, No. 713, OECD Publishing, Paris.

Myles, G. D. (2009b), "Economic Growth and the Role of Taxation - Aggregate Data," OECD Economics Department Working Papers, No. 714, OECD Publishing, Paris.

Newey, W. K., and K. D. West (1987), “A Simple, Positive Semi-Definite, Heteroskedasticity and Autocorrelation Consistent Covariance Matrix”, Econometrica, Vol. 55, No. 3, pp. 703-708.

Nickell, S. (1981), "Biases in Dynamic Models with Fixed Effects", Econometrica, Vol. 49, No. 6, pp. 1417-26.

OECD (2006), The Political Economy of Environmentally Related Taxes, OECD Publishing, Paris.

OECD (2010), "Choosing a Broad Base Low Rate Approach to Taxation," OECD Tax Policy Studies, No. 19, OECD Publishing, Paris.

OECD (2011), Divided We Stand: Why Inequality Keeps Rising, OECD Publishing, Paris.

OECD (2014a), The Distributional Effects of Consumption Taxes in OECD Countries, OECD Publishing, Paris.

OECD (2014b), "Long-term Baseline Projections”, OECD Economic Outlook: Statistics and Projections (database), http://dx.doi.org/10.1787/data-00690-en.

OECD (2014c), "PISA 2012 Results: What Students Know and Can Do, Student Performance in Mathematics, Reading and Science", Vol. I, revised edition, OECD Publishing, Paris.

OECD (2016a), Revenue Statistics 2016, OECD Publishing, Paris.

OECD (2016b), OECD Economic Outlook No. 100, OECD Publishing, Paris.

OECD (2016c), Tax Policy Reforms 2016, OECD Publishing, Paris.

OECD (2017a), Taxing Wages, OECD Publishing, Paris.

OECD (2017b), Tax Policy Reforms 2017, OECD Publishing, Paris.

Orphanides, A. and S. van Norden (2002), "The Unreliability of Output-Gap Estimates in Real Time", The Review of Economics and Statistics, Vol. 84, No. 4, pp. 569-583.

Oueslati, W., V. Zipperer, D. Rousselière and A. Dimitropoulos (2016), "Exploring the Relationship between Environmentally Related Taxes and Inequality in Income Sources", OECD Environment Working Papers, No. 100, OECD Publishing, Paris.

Pestel, N. and E. Sommer (2017), "Shifting Taxes from Labor to Consumption: More Employment and More Inequality", Review of Income and Wealth, Series 63, No. 3. 


\section{ECO/WKP(2017)79}

Piketty, T. and E. Saez (2013), “Optimal Labor Income Taxation”, in Auerbach, A. et al. (ed.), Handbook of Public Economics, Chapter 7, pp. 391-474, Elsevier.

Phillips, P. C. and M. Loretan (1991), "Estimating Long-run Economic Equilibria", The Review of Economic Studies, 58(3), 407-436.

Piketty, T. and E. Saez (2007), "How Progressive is the US Federal Tax System? A Historical and International Perspective", Journal of Economic Perspectives, Vol. 21, Issue 1, pp. 3-24.

Pinault, L., A. van Donkelaar and R. Martin (2017), "Exposure to Fine Particulate Matter Air Pollution in Canada", Health Reports, Vol. 28, Issue 3, Statistics Canada.

Ruiz, N. and N. Woloszko (2016), "What Do Household Surveys Suggest about the Top 1\% Incomes and Inequality in OECD Countries?", OECD Economics Department Working Paper, No. 1265, OECD Publishing, Paris.

Saikkonen, P. (1991), “Asymptotically Efficient Estimation of Cointegration Regressions”, Econometric Theory, 7(1), pp. 1-21.

Seim, D. (2017), "Behavioral Responses to Wealth Taxes: Evidence from Sweden", American Economic Journal: Economic Policy, Vol. 9, Issue 4, pp. 395-421.

Schimanski, C. (2017), "Earnings Shocks and Tax-motivated Income Shifting: Evidence from European Multinationals - Revisited", Applied Economics Letters, Vol. 24, Issue 21, pp. 1558-1566.

Serret, Y. and N. Johnstone, Ed., (2006), The Distributional Effects of Environmental Quality, Edward Elgar.

Song, J., D. Price, F. Guvenen, N. Bloom and T. von Wachter (2016), "Firming Up Inequality," mimeo dated 22 October 2016, downloaded 31 August 2017 from http://bit.ly/2escfXD.

Schwellnus, C. and J. Arnold (2008), "Do Corporate Taxes Reduce Productivity and Investment at the Firm Level? Cross-Country Evidence from the Amadeus Dataset", OECD Economics Department Working Papers, No. 641, OECD Publishing, Paris.

Stock, J. H. and M.W. Watson (1993), “A Simple Estimator of Cointegrating Vectors in Higher Order Integrated Systems", Econometrica, Vol. 61, No. 4, pp. 783-820.

Tanzi, V. (1995), Taxation in an Integrating World, The Brookings Institute, Washington DC.

Van den Noord, P. and C. Heady (2002), "Tax Design, Economic Efficiency and Growth", in The Impact of Fiscal Policy, Banca d'Italia.

Vartia, L. (2009), "How Do Taxes Affect Investment and Productivity? An Industry-Level Analysis of OECD Countries", OECD Economics Department Working Papers, No. 656, OECD Publishing, Paris.

White, H. (1980), “A Heteroskedasticity-Consistent Covariance Matrix Estimator and a Direct Test for Heteroskedasticity", Econometrica, Vol. 48, No. 4, pp. 817-838.Xing, J. (2012), "Tax Structure and Growth: How Robust is the Empirical Evidence?”, Economics Letters, Vol. 117, pp. 379-382. 